\title{
Interaction of nickel-based SOFC anodes with trace contaminants from coal-derived synthesis gas
}

\author{
Gregory Allen Hackett \\ West Virginia University
}

Follow this and additional works at: https://researchrepository.wvu.edu/etd

\section{Recommended Citation}

Hackett, Gregory Allen, "Interaction of nickel-based SOFC anodes with trace contaminants from coalderived synthesis gas" (2009). Graduate Theses, Dissertations, and Problem Reports. 2938.

https://researchrepository.wvu.edu/etd/2938

This Dissertation is protected by copyright and/or related rights. It has been brought to you by the The Research Repository @ WVU with permission from the rights-holder(s). You are free to use this Dissertation in any way that is permitted by the copyright and related rights legislation that applies to your use. For other uses you must obtain permission from the rights-holder(s) directly, unless additional rights are indicated by a Creative Commons license in the record and/ or on the work itself. This Dissertation has been accepted for inclusion in WVU Graduate Theses, Dissertations, and Problem Reports collection by an authorized administrator of The Research Repository @ WVU.

For more information, please contact researchrepository@mail.wvu.edu. 


\title{
INTERACTION OF NICKEL-BASED SOFC ANODES WITH TRACE CONTAMINANTS FROM COAL-DERIVED SYNTHESIS GAS
}

\author{
Gregory Allen Hackett
}

\author{
Dissertation submitted to the \\ College of Engineering and Mineral Resources \\ at West Virginia University \\ in partial fulfillment of the requirements \\ for the degree of
}

Doctor of Philosophy in Chemical Engineering

John W. Zondlo, Ph.D., Chair Eung H. Cho, Ph.D.

Kirk R. Gerdes, Ph.D. Xingbo Liu, Ph.D.

Charter D. Stinespring, Ph.D.

Department of Chemical Engineering

West Virginia University

Morgantown, West Virginia 2009

Keywords: SOFC, Fuel Cell, Coal, Syngas, Trace Species, Ni-YSZ Anode 


\title{
ABSTRACT \\ Interaction of Nickel-Based SOFC Anodes with Trace Contaminants from Coal-Derived Synthesis Gas
}

\author{
Gregory A. Hackett
}

\begin{abstract}
New and efficient methods of producing electrical energy from natural resources have become an important topic for researchers. Integrated gasification and fuel cell (IGFC) systems offer a fuel-flexible, high-efficiency method of energy generation. Specifically, in coal gasification processes, coal can be changed into a high-quality gaseous fuel suitable for feeding solid oxide fuel cells (SOFCs). However, trace species found in coal synthesis gas (syngas) may have a deleterious effect on the performance of nickel-based SOFC anodes. Generally, the cost of removing these species down to parts per million (ppm) levels is high.

The purpose of this research is to determine the highest amount of contaminant that results in a low rate $(\sim 1 \%$ per $1000 \mathrm{~h})$ of cell performance degradation, allowing the SOFC to produce usable power for 40,000 hours. The cell performance degradation rate was determined for benzene, naphthalene, and mercury-doped syngas based on species concentration. Experimental data are fitted with degradation models to predict cell lifetime behavior. From these results, the minimum coal syngas cleanup required for these trace materials is determined. It is found that for a final cell voltage of $0.6 \mathrm{~V}$, naphthalene and benzene must be cleaned to $360 \mathrm{ppm}$ and less than $150 \mathrm{ppm}$, respectively. No additional cleaning is required for mercury beyond established environmental standards.

Additionally, a detailed attack and recovery mechanism is proposed for the hydrocarbon species and their interaction with the fuel cell. This mechanism is proposed by considering the type of degradation models predicted and how carbon would interact with the Ni-YSZ anode to justify those models. The mechanism postulates that carbon is diffusing into the nickel structure, creating a metal solution. Once the nickel is saturated, the carbon begins to deposit on the nickel surface, reducing the electrode active area. The formation of metal solutions and the deposition of carbon results in reduced cell productivity.
\end{abstract}




\section{ACKNOWLEDGEMENT}

Primarily, I would like to acknowledge my wife, Tessa Hackett, for her patience and support throughout my graduate studies.

I would also like to acknowledge Dr. John Zondlo, who put large amounts of time and effort into making this research and dissertation the best quality that it could be. Thank you for your guidance, suggestions, and thoughtful feedback.

Thanks also to Dr. Kirk Gerdes for technical direction and guidance. Thank you for providing the opportunity to conduct this research at the National Energy Technology Laboratory in Morgantown, West Virginia. Thank you for your time and consideration for this research and this dissertation. Thank you for obtaining funding for this research and my efforts. Also, thanks to the rest of my research advisory committee, Dr. Eung Cho, Dr. Xingbo Liu, and Dr. Charter Stinespring for their help and support for this research and dissertation preparation.

Thanks to the Chemical Engineering Department at West Virginia University, for its dedication to higher learning and its students. Thank you Dr. Rakesh Gupta and Dr. Dady Dadyburjor, the chairs of the department during my graduate studies, for their commitment, support, and dedication to the department.

Thanks to James Poston, Jr., for his expert assistance in the analytical laboratory at NETL. In addition, thanks to Dr. Randall Gemmen, the fuel cell group team leader at NETL for his pointed guidance and thoughtful consideration for this research. Additionally, thanks to Dr. Harry Finklea and the C. Eugene Bennett Department of Chemistry at WVU for overseeing my funding and travel arrangements during the research period. 


\section{CONTENTS}

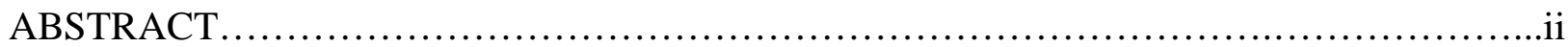

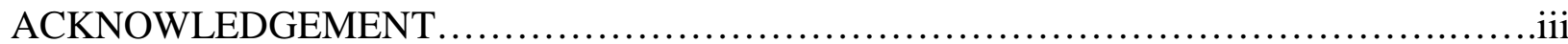

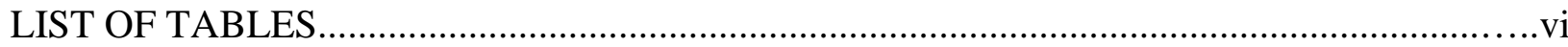

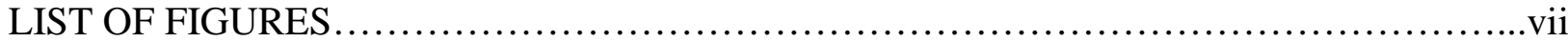

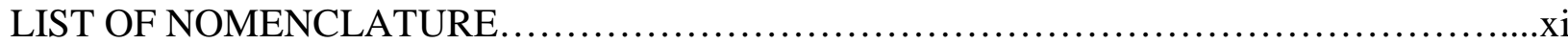

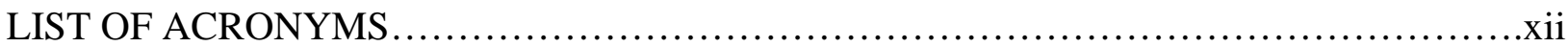

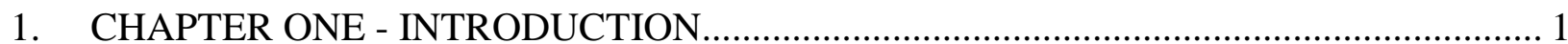

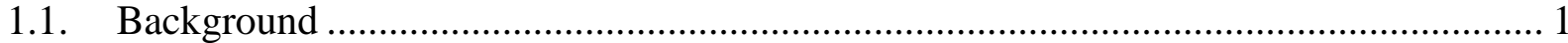

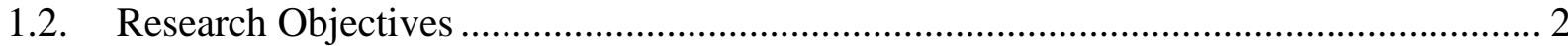

1.3. Expected Results and Benefits of Research ............................................................ 4

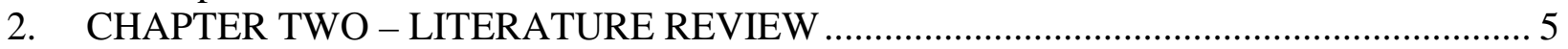

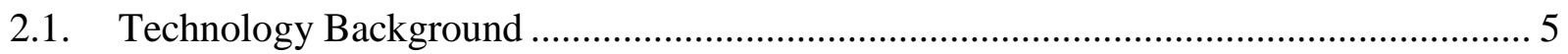

2.1.1. Syngas as a Fuel for SOFCs …………............................................................ 5

2.1.2. SOFCs Operating on Simulated Clean Syngas .......................................................... 9

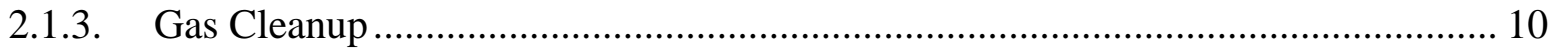

2.1.4. SOFCs Operating on Direct Coal Syngas ................................................................... 13

2.2. The Effect of Coal Syngas Trace Species on SOFC Performance.................................. 14

2.2.1. Group VI Element - Sulfur (S)......................................................................... 15

2.2.2. Group VI Element - Selenium (Se)................................................................... 19

2.2.3. Group VII Element - Chlorine $(\mathrm{Cl})$.................................................................. 21

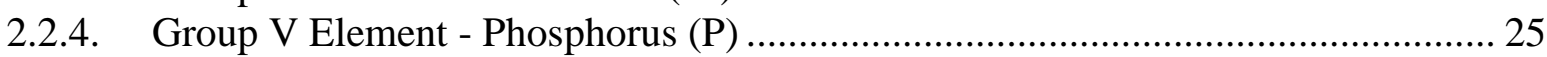

2.2.5. Group V Element - Arsenic (As) …………………........................................... 29

2.2.6. Group V Element - Antimony (Sb)................................................................... 33

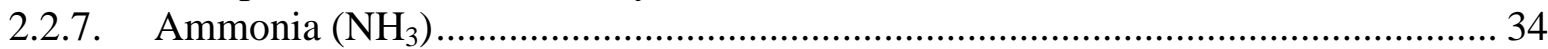

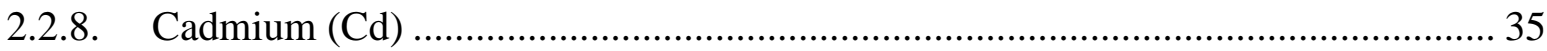

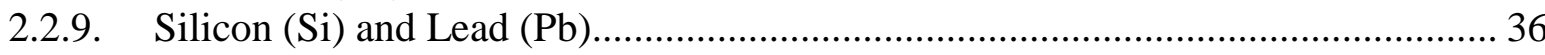

2.2.10. Mercury (Hg)......................................................................................... 36

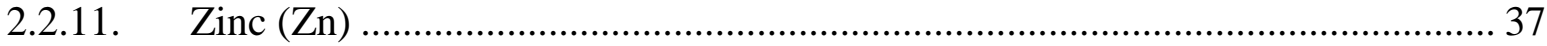

2.2.12. Carbon (C) Deposition on Nickel Surfaces...................................................... 38

3. CHAPTER THREE - EXPERIMENTAL WORK ............................................................ 43

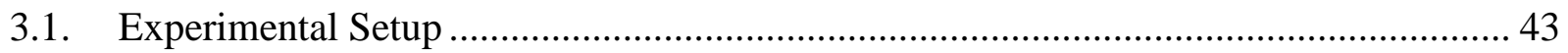

3.2. Experimental Procedure and Analysis ........................................................................ 46

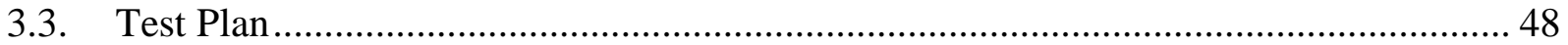

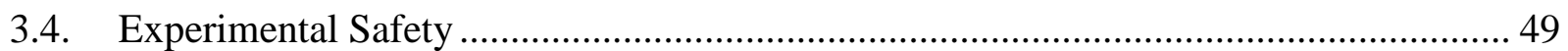

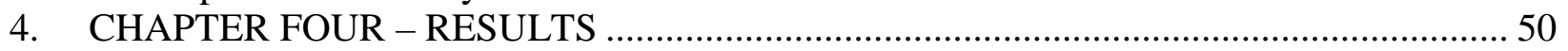

4.1. Mercury Exposure -1 ppm..................................................................................... 50

4.2. $\quad$ Mercury Exposure -10 ppm................................................................................. 52

4.3. Benzene Exposure - 15 ppm................................................................................. 54

4.4. Benzene Exposure - 150 ppm ............................................................................... 56

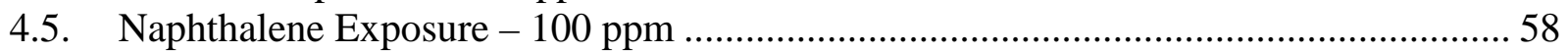

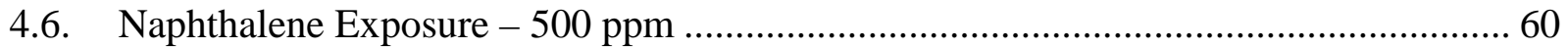

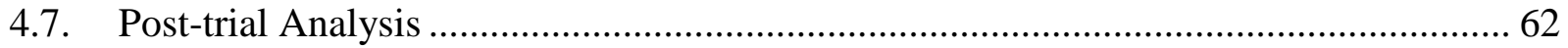

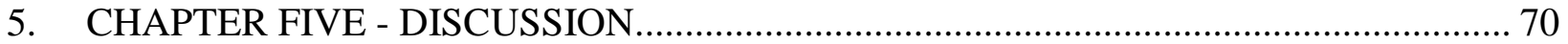




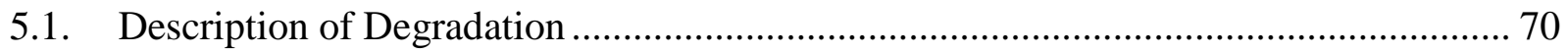

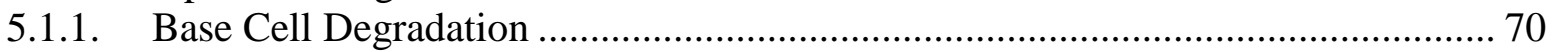

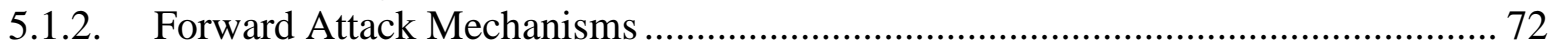

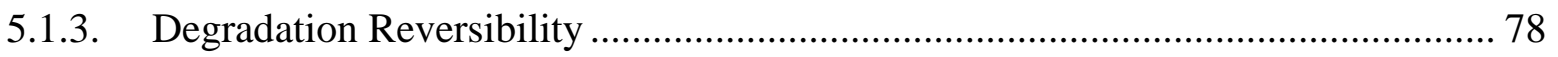

5.1.4. Sensitivity to Bulk Gas Concentration and Materials of Construction .................... 80

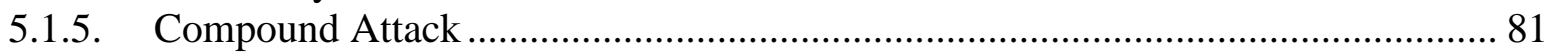

5.2. Application of Mechanisms to Observed Data ............................................................ 82

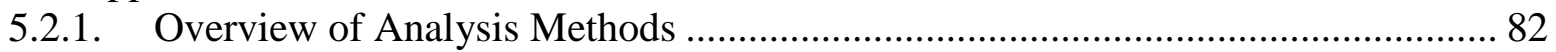

5.2.2. Model Application to Experimental Data ..................................................................... 84

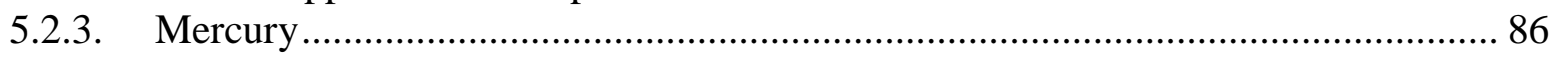

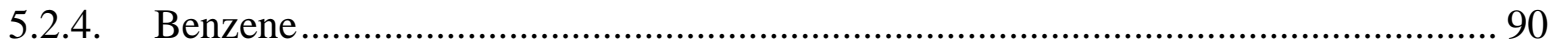

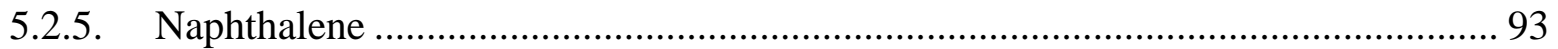

5.2.6. Cell Output Improvement upon Addition of Hydrocarbon Fuel .............................. 96

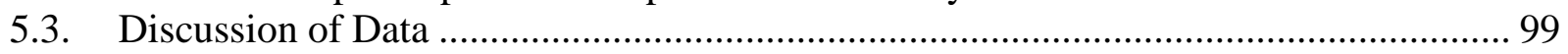

6. CHAPTER SIX - POSTULATED MECHANISMS OF HYDROCARBON ATTACK .. 102

6.1. Deposition Mechanism........................................................................................ 102

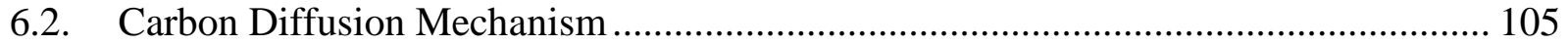

6.3. Carbon Induced Nickel Corrosion.................................................................................. 107

6.4. Carbon Removal (Reverse) Mechanism .............................................................. 108

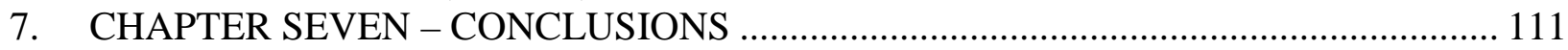

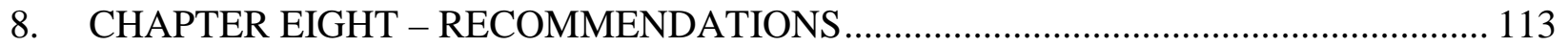

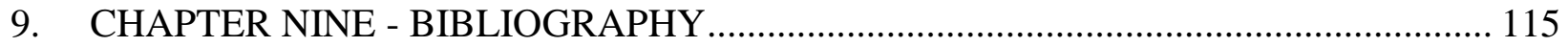




\section{LIST OF TABLES}

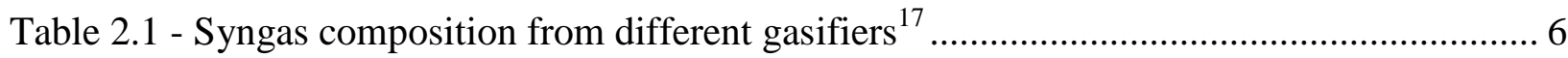

Table 2.2 - Trace elements and their concentration in coal syngas as reported at the Kingsport

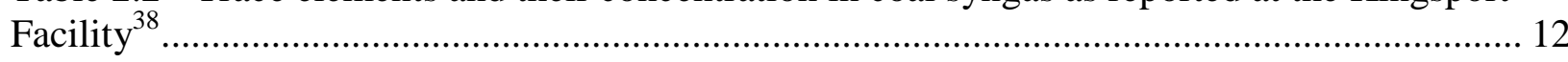

Table 2.3 - Comparison of Different Power Generation Techniques ${ }^{12}$.................................... 14

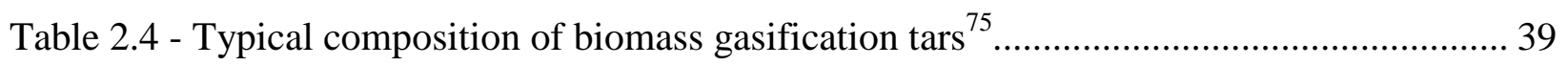

Table 5.1 - Summary of Results for 1 ppm Mercury Exposure.............................................. 87

Table 5.2 - Summary of Results for 10 ppm Mercury Exposure ............................................ 88

Table 5.3 - Summary of Results for 15 ppm Benzene Exposure ............................................ 91

Table 5.4 - Summary of Results for 150 ppm Benzene Exposure........................................... 92

Table 5.5 - Summary of Results for 100 ppm Naphthalene Exposure .................................... 94

Table 5.6 - Summary of Results for 500 ppm Naphthalene Exposure ..................................... 95

Table 6.1 - Summary of Performance Decrease for Each Hydrocarbon Experiment Conducted and the Predicted Carbon Deposition per gram of Ni-YSZ ................................................... 105

Table 6.2 - Carbon Deposition and Removal Rates for Each Hydrocarbon Experiment ........... 110 


\section{TABLE OF FIGURES}

Figure 2.1 - Calculated Ni-S phase diagram. The upper region is the predicted clean Ni surface phase, the middle region represents the absorbed sulfur atoms on $\mathrm{Ni}$ surface phases and the lower region is the $\mathrm{Ni}_{2} \mathrm{~S}_{3}$ bulk phase. ${ }^{58}$.

Figure 2.2 - Cell potential as a function of operating time for exposure to syngas containing 5 ppm $\mathrm{H}_{2}$ Se at $800^{\circ} \mathrm{C}$ and $0.25 \mathrm{~A} / \mathrm{cm}^{247}$.

Figure 2.3 - Cell potential as a function of operating time for exposure to syngas containing 0.5 ppm $\mathrm{H}_{2}$ Se at $800^{\circ} \mathrm{C}$ and $0.25 \mathrm{~A} / \mathrm{cm}^{2}{ }^{47}$. 21

Figure 2.4 - SOFC power density operating at $800^{\circ} \mathrm{C}$ and $0.7 \mathrm{~V}$ over time with $\mathrm{HCl}$ concentrations of 0,20 , and $160 \mathrm{ppm}^{24}$.

Figure 2.5 - SOFC power density curves at $900^{\circ} \mathrm{C}$ and $0.7 \mathrm{~V}$ over time with $\mathrm{HCl}$ concentrations of 0,20 , and $160 \mathrm{ppm}^{24}$

Figure 2.6 - Surface morphology of the cell after exposure to $35 \mathrm{ppm} \mathrm{PH}_{3}$. a) SEM photo micrograph b) X-ray elemental map

Figure 2.7 - SOFC performance of cell operating at $800^{\circ} \mathrm{C}$ exposed to $2 \mathrm{ppm} \mathrm{PH}_{3}$ in coal syngas $^{48}$

Figure $2.8-\mathrm{AsH}_{3}$ equilibrium partial pressures for Equation 2.19 over SOFC operational temperature range and $0.29 \mathrm{~atm}_{2}{ }^{41}$.

Figure 2.9 - SOFC performance at $800^{\circ} \mathrm{C}$ and $0.25 \mathrm{~A} / \mathrm{cm}^{2}$ with fuel containing $0.1 \mathrm{ppm} \mathrm{AsH}_{3}$ (the time prior to $\mathrm{AsH}_{3}$ injection is not shown) ${ }^{41}$.

Figure 2.10 - Equilibrium diagram of main species as a function of current density for a mixture comprising $20 \% \mathrm{CO}, 15 \% \mathrm{H}_{2}, 10 \% \mathrm{CO}_{2}, 5 \% \mathrm{H}_{2} \mathrm{O}, 2 \% \mathrm{CH}_{4}, 48 \% \mathrm{~N}_{2}$, and tar as $2 \%$ of the total mixture at $750^{\circ} \mathrm{C}$.

Figure 3.1 - Schematic of SOFC Mounting Apparatus.

Figure 3.2 - Photograph of mounted cell ready for installation into the test stand for experimentation.

Figure 3.3 - Photograph of entire fuel cell test stand apparatus including (from left) data collection, load bank, temperature controllers, furnace, Dynacalibrator 150, and humidification tank.

Figure 3.4 - Schematic diagram of flow path. All fuel lines downstream of the humidification tank are heat traced above $150^{\circ} \mathrm{C}$. 
Figure 4.1 - The potential response and current density of a SOFC exposed to syngas doped with $1 \mathrm{ppm}$ mercury for $500 \mathrm{~h}$ at $800^{\circ} \mathrm{C}$....................................................................................... 51

Figure 4.2 - Impedance plots at various times of exposure during the $500 \mathrm{~h}$ operation period of a button cell exposed to syngas doped with $1 \mathrm{ppm}$ mercury at $800^{\circ} \mathrm{C}$............................................ 51

Figure 4.3 - The potential response and current density of a SOFC exposed to syngas doped with

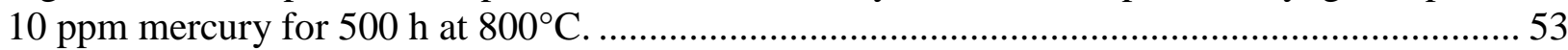

Figure 4.4 - Impedance plots at various times during the $500 \mathrm{~h}$ operation period of a button cell exposed to syngas doped with $10 \mathrm{ppm}$ mercury at $800^{\circ} \mathrm{C}$........................................................... 53

Figure 4.5 - Polarization resistance as a function of time for 1 and $10 \mathrm{ppm}$ mercury exposure. The small magnitude of the resistance increase indicates that no appreciable cell degradation is occurring on this time scale.

Figure 4.6 - The potential response and current density of a SOFC exposed to syngas doped with

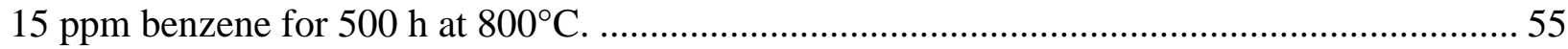

Figure 4.7 - Impedance plots at several times during the $500 \mathrm{~h}$ operation period of a button cell exposed to syngas doped with $15 \mathrm{ppm}$ benzene at $800^{\circ} \mathrm{C}$.......................................................... 56

Figure 4.8 - The potential response and current density of a button cell exposed to syngas doped with $150 \mathrm{ppm}$ benzene for $500 \mathrm{~h}$ at $800^{\circ} \mathrm{C}$. ............................................................................. 57

Figure 4.9 - Impedance plots at various times during the $500 \mathrm{~h}$ operation period of a button cell exposed to syngas doped with $150 \mathrm{ppm}$ benzene at $800^{\circ} \mathrm{C}$......................................................... 57

Figure 4.10 - Polarization resistance as a function of time for 15 and $150 \mathrm{ppm}$ benzene exposure. In this case, the change in resistance is negligible, indicating that minimal cell degradation is occurring. 58

Figure 4.11 - The potential response and current density of a button cell exposed to syngas doped with $100 \mathrm{ppm}$ naphthalene for $500 \mathrm{~h}$ at $800^{\circ} \mathrm{C}$.

Figure 4.12 - Impedance plots at various times during the $500 \mathrm{~h}$ operation period of a button cell exposed to syngas doped with $100 \mathrm{ppm}$ naphthalene at $800^{\circ} \mathrm{C}$. 60

Figure 4.13 - The potential response and current density of a button cell exposed to syngas doped with $500 \mathrm{ppm}$ naphthalene for $500 \mathrm{~h}$ at $800^{\circ} \mathrm{C}$.

Figure 4.14 - Impedance plots at various times during the $500 \mathrm{~h}$ operation period of a button cell exposed to syngas doped with $500 \mathrm{ppm}$ naphthalene at $800^{\circ} \mathrm{C}$.

Figure 4.15 - Polarization resistance as a function of time for 100 and $500 \mathrm{ppm}$ naphthalene exposure. Resistance increase indicates a modest degradation in cell performance. 62 
Figure 4.16 - Scanning electron microscope picture of the cross section an unreacted SOFC

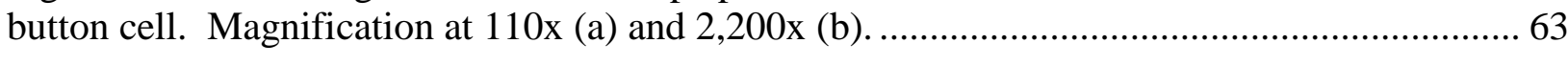

Figure 4.17 - Isotopic fingerprint for mercury detected by GC-ICP/MS in fuel flow upstream of fuel cell.

Figure 4.18 - XPS results of carbon for a button cell exposed to $15 \mathrm{ppm}$ benzene for $500 \mathrm{~h}$ at $800^{\circ} \mathrm{C}$. Graphitic carbon has a binding energy of $284.8 \mathrm{eV}$. The peak is not larger than the observed noise levels.

Figure 4.19 - XPS results of carbon for a button cell exposed to $150 \mathrm{ppm}$ benzene for $500 \mathrm{~h}$ at $800^{\circ} \mathrm{C}$. Graphitic carbon has a binding energy of $284.8 \mathrm{eV}$. The peak is not larger than the observed noise levels.

Figure 4.20 - XPS results of carbon for a button cell exposed to $100 \mathrm{ppm}$ naphthalene for $500 \mathrm{~h}$ at $800^{\circ} \mathrm{C}$. Hydrogen treated button cell is shown as a reference. Graphitic carbon has a binding energy of $284.8 \mathrm{eV}$. The peak is slightly larger than observed noise levels as shown in the curve for the hydrogen treated sample. The peak at $282.5 \mathrm{eV}$ was not able to be determined. ........... 68

Figure 4.21 - XPS results of carbon for a button cell exposed to $500 \mathrm{ppm}$ naphthalene for $500 \mathrm{~h}$ at $800^{\circ} \mathrm{C}$. Hydrogen treated button cell is shown as a reference. Graphitic carbon has a binding energy of $284.8 \mathrm{eV}$. The peak is slightly larger than observed noise levels. The identity of the peak at $282.2 \mathrm{eV}$ likely corresponds to a nickel-carbide phase.

Figure 5.1 - YSZ Unit Cell Crystal Structure 71

Figure 5.2 - Triple phase boundary illustration where fuel is incorporated into the electrolyte (1), fuel diffuses to the electrolyte/catalyst interface (2), and fuel reacts at catalyst surface (3). At (4), a contaminant is blocking the active TPB site, hindering reaction. 73

Figure 5.3 - Nickel-carbon phase diagram. ${ }^{88}$ 76

Figure 5.4 - Depiction of known cell performance degradation patterns when exposed to coal contaminants. Immediate precipitous dropout followed by slow decay (a - top left), fast initial decay followed by a slow, linear decay rate (b - top right), slow linear decay followed by sudden drop (c - bottom left), degradation increasing over time ( $\mathrm{d}$ - bottom right). 78

Figure 5.5 - Depiction of performance output for a cell undergoing a compound attack mechanism.

Figure 5.6 - Depiction of dual-phase degradation analysis method where $t_{c}$ is the time when the instantaneous degradation rate equals the assumed baseline degradation rate.

Figure 5.7 - Curves showing single-phase linear (left) and single-phase exponential (right) fits for 1 and 10 ppm mercury..... 
Figure 5.8 - Curves showing single-phase linear (left) and single-phase exponential (right) fits for 15 and 150 ppm benzene.

Figure 5.9 - Predicted potential for a cell lifetime of 40,000 h based on benzene concentration and assumed baseline cell degradation rates of a) $1.0 \%$ per kh b) $0.50 \%$ per kh c) $0.25 \%$ per kh.

Figure 5.10 - Curves showing single-phase linear and single-phase exponential fits for 100 and

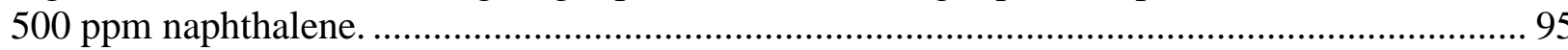

Figure 5.11 - Predicted potential for a cell lifetime of 40,000 h based on naphthalene concentration and assumed baseline cell degradation rates of a) $1.0 \%$ per kh b) $0.50 \%$ per kh c) $0.25 \%$ per $\mathrm{kh}$. Please note that the exponential decay model only operates for a short time

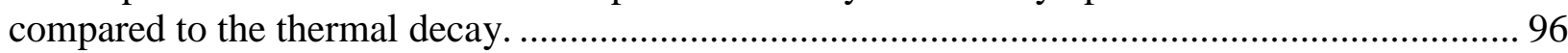

Figure 5.12 - Nickel-carbon phase diagram............................................................. 101

Figure 6.1 - Illustration of the reactions identified for carbon diffusion into nickel (111). ${ }^{99} \ldots . .107$ 


\section{LIST OF NOMENCLATURE}

\begin{tabular}{|c|c|c|}
\hline$a_{C}$ & Supersaturated Carbon Activity & [-] \\
\hline A & Current & [A] \\
\hline AS & Active Sites & {$[-]$} \\
\hline $\mathrm{C}$ & Concentration & {$\left[\mathrm{g} / \mathrm{cm}^{3}\right]$} \\
\hline $\mathrm{C}$ & Carbon Concentration & [g C / g Ni-YSZ] \\
\hline $\mathrm{CH}_{\mathrm{z}}$ & Carbon Macromolecule Concentration & [g CH $/ \mathrm{g} \mathrm{Ni-YSZ]}$ \\
\hline $\mathrm{D}$ & Diffusion Coefficient & {$\left[\mathrm{cm}^{2} / \mathrm{s}\right]$} \\
\hline$E^{0}$ & Standard Reaction Potential & [V] \\
\hline$E_{0}$ & Baseline Cell Potential & {$[\mathrm{V}]$} \\
\hline $\mathrm{E}_{\mathrm{N}}$ & Nernst Potential & [V] \\
\hline$\Delta \mathrm{G}^{0}$ & Standard Gibbs Free Energy of Formation & {$[\mathrm{kJ} / \mathrm{mol}]$} \\
\hline$\Delta \mathrm{H}$ & Enthalpy of Formation & {$[\mathrm{kJ} / \mathrm{mol}]$} \\
\hline K & Equilibrium Constant & {$[-]$} \\
\hline $\mathrm{k}_{\mathrm{x}}$ & Reaction 'X' Rate Constant & {$\left[\mathrm{mg} /\left(\mathrm{cm}^{3 \times a t m} \times \mathrm{h}\right)\right]$} \\
\hline $\mathrm{N}$ & Available Ni-YSZ Active Reaction Sites & [AS/g Ni-YSZ] \\
\hline $\mathrm{N}_{0}$ & Initial available Ni-YSZ Active Sites & [AS/g Ni-YSZ] \\
\hline $\mathrm{p}_{\mathrm{x}}$ & Partial Pressure of Specie 'X' & [atm] \\
\hline $\mathrm{R}$ & Gas Constant & {$[(\mathrm{L} \times \mathrm{atm}) /(\mathrm{mol} \times \mathrm{K})]$} \\
\hline $\mathrm{R}_{\mathrm{P}}$ & Polarization Resistance & [ $\Omega]$ \\
\hline $\mathrm{R}_{\mathrm{S}}$ & Series Resistance & 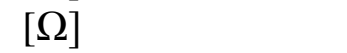 \\
\hline$r_{x}$ & Rate of Reaction ' $\mathrm{X}$ ' & {$\left[\mathrm{mg} /\left(\mathrm{cm}^{3} \times \mathrm{h}\right)\right]$} \\
\hline $\mathrm{S}$ & Total Amount of Solute for Diffusion & {$\left[\mathrm{g} / \mathrm{cm}^{2}\right]$} \\
\hline $\mathrm{T}$ & Temperature & {$[\mathrm{K}]$} \\
\hline $\mathrm{t}$ & Time & [h] \\
\hline $\mathrm{t}_{0}$ & Initial Exposure Time & [h] \\
\hline$t_{C}$ & Phase Crossover Time & [h] \\
\hline$t_{f}$ & Final Exposure Time & [h] \\
\hline $\mathrm{V}$ & Potential & [V] \\
\hline$\delta$ & Carbon to Nickel AS Conversion Coefficient & {$\left[\mathrm{AS}^{2} / \mathrm{g} \mathrm{C}\right]$} \\
\hline
\end{tabular}




\section{LIST OF ACRONYMS}

DFT

EBSD

EDS

EIS

EPA

GC-ICP/MS

GDC

$\mathrm{HHC}$

IGCC

IGFC

KBR

LSCF

LSM

MCFC

MFC

MOC

MSDS

MSR

NETL

OCV

PCD

PFBC

PSDF

SARS

ScSZ

SEM

SOFC

TEM

TPB

USDOE

WGS

XPS

XRD

YSZ
Density Functional Theory

Electron Backscatter Diffraction

Energy Dispersive Spectroscopy

Electrochemical Impedance Spectroscopy

Environmental Protection Agency

Gas Chromatograph - Inductively Coupled Plasma Mass Spectrometer

Gadolinium Doped Ceria

Higher Hydrocarbon

Integrated Gasification Combined Cycle system

Integrated Gasification and Fuel Cell system

Kellogg, Brown, and Root, Inc.

Lanthanum Strontium Cobalt Ferrite

Lanthanum Strontium Manganate

Molten Carbonate Fuel Cell

Mass Flow Controller

Material of Construction

Material Safety Data Sheet

Methane-Steam Reforming Reaction

National Energy Technology Laboratory

Open Circuit Voltage (Potential)

Particulate Collection Device

Pressurized Fluidized Bed Combustion

Power Systems and Development Facility (Wilsonville, AL)

Safety Analysis and Review System

Scandia Stabilized Zirconia

Scanning Electron Microscopy

Solid Oxide Fuel Cell

Transmission Electron Microscopy

Triple-Phase Boundary

United States Department of Energy

Water-Gas Shift Reaction

X-Ray Photoelectron Spectroscopy

X-Ray Diffraction

Yttria Stabilized Zirconia 


\section{CHAPTER ONE - INTRODUCTION}

\subsection{Background}

Coal is the most abundant fossil fuel in the United States ${ }^{1}$, and its environmentally benign and efficient utilization is the focus of $\$ 2$ billion in federal research funding expended over ten years, as initiated in the Presidential Clean Coal Power Initiative of $2002^{2}$. The Recovery and Reinvestment Act of 2009 has also allocated \$2.4 billion for clean coal and carbon capture research. $^{3}$

Coal gasification is a highly efficient method of converting coal into usable energy ${ }^{4}$ and designs typified by Kellogg, Brown, and Root, Inc. (KBR), Westinghouse, etc. have been used to produce coal synthesis gas (syngas). Although some gasification facilities exist for research scale development, some commercial operations for power generation also exist such as those at Eastman Industrial Gasification in Kingsport, Tennessee and Tampa Electric in Tampa, Florida ${ }^{5}$

An important energy conversion device demonstrating advantageous technical characteristics is the fuel cell. , $7,8,9$ Fuel cells produce high fuel-to-electricity conversion efficiencies and emit low levels of $\mathrm{NO}_{\mathrm{X}}$ and $\mathrm{SO}_{\mathrm{X}}$. In particular, solid oxide fuel cells (SOFCs) are promising because of their high thermodynamic efficiency, fuel flexibility, and benign environmental impact.

Integrated gasification and fuel cell (IGFC) systems offer enhanced energy conversion

efficiency and superior carbon sequestration methods ${ }^{10,11}$. Kuchonthara et al. ${ }^{10}$ describe a process for integration that enhances carbon capture capability and raises overall cycle efficiency from $39.5 \%$ (thermochemical recuperative coal gasification combined cycle only) to $45.0 \%$ by including a SOFC downstream. Kivisaari et al. ${ }^{12}$ predicted a power efficiency of $46.7 \%$ for an IGFC system utilizing a SOFC and anode gas recycle. 
One critical consideration for IGFC systems is the interaction of trace species from the gasification process with the SOFC anode, which commonly contains nickel. Owing to the natural elemental content of coal, syngas derived from coal gasification may contain gas phase trace species covering nearly every element on the periodic table ${ }^{13}$. Unfortunately, the trace elemental composition of the syngas is not readily predictable as it varies with gasifier design, gas cleanup process, coal type, and regional source of the coal. Limited data exist for SOFC operation on direct syngas ${ }^{14,15}$, and the specific interactions of trace syngas species with the SOFC anode are not completely understood.

In order to generate trace element cleanup targets for IGFC applications, data describing deleterious interactions must be collected within a large parameter space spanning operating temperature, syngas composition (including trace elements), electrode composition, and current density, among other parameters. At present, there is a small amount of information available on the effects that trace materials in coal will have on a SOFC anode. Research has been conducted using thermodynamic analysis and predictions to narrow the scope to species that will pass through syngas cleanup processes ${ }^{16}$. Such elements include mercury (Hg), cadmium (Cd), lead $(\mathrm{Pb})$, antimony $(\mathrm{Sb})$, phosphorus $(\mathrm{P})$, chlorine $(\mathrm{Cl})$, arsenic $(\mathrm{As})$, and zinc $(\mathrm{Zn})$. It is also expected that higher hydrocarbons (HHCs) will pass through warm-gas cleanup methods. These elements, along with other molecules (such as $\mathrm{HCl}, \mathrm{CH}_{3} \mathrm{Cl}$, and $\mathrm{NH}_{3}$ ) have been studied for their effects on SOFC anodes.

\section{2. $\quad$ Research Objectives}

The focus of this research is to investigate the effects of a few of the previously mentioned coal syngas trace materials. Specifically, the focus is on higher hydrocarbons (benzene and naphthalene), and mercury. The cell performance degradation rate is reported over a period of 
1000 hours, based on potential/power output. The proposed "acceptable" degradation rate for this amount of time is $\sim 1 \%$ per $1000 \mathrm{~h}$.

A detailed mechanism of attack is proposed for the hydrocarbon species. This mechanism shows the specific route of attack on the nickel-based SOFC anode. This may include the blocking of active (reaction) sites at the triple-phase boundary (TPB) due to surface adsorption, where the electrolyte, nickel, and fuel are all present for reaction. The attack method may also be the formation of non-reactive secondary phases of the nickel with the specie of interest. This has been demonstrated, for example, by the phases formed when the anode is exposed to phosphorus containing syngas. ${ }^{16}$ Another method of attack is the physical blocking of the fuel flow channels within the anode, effectively starving the electrochemical reaction of fuel.

From the results of this research, it is possible to predict a degradation rate for benzene, naphthalene, and mercury. From this, the concentration that causes the cell to operate at a specified minimum potential (predicted for 0.6 and $0.7 \mathrm{~V}$ ) after 40,000 hours of operation will be considered the minimum required cleanup for that specie. The proposed detailed mechanism gives insight into how the anode can be engineered to be impervious to the attack of carbon, giving it a longer lifetime.

In order to complete the work for this research efficiently, the overall objectives are broken down into individual tasks. The tasks were as follows: 1) a completion of a literature review to become informed of other similar research and up-to-date progress made in this area, 2) a modification of available experimental apparatus to fit the research needs, including incorporation of additional equipment, 3) the experimental design, and completion of an experimental investigation for trace species that have not yet been fully explored, and 4) an analysis of the generated data resulting in a detailed statistical analysis and a proposed detailed 
reaction mechanism for the hydrocarbon trace species. The sections below provide further detail on each of these tasks.

\subsection{Expected Results and Benefits of Research}

The results of the proposed tests provide information that is vital to coal syngas cleanup design and operation as well as SOFC material design. Higher hydrocarbon species found in coal syngas are expected to cause cell performance degradation due to the blocking of active sites, the physical plugging of fuel flow channels, or carbon dissolution into the nickel matrix within the SOFC anode. This may be prevented by having a significant amount of water vapor in the syngas stream or by other methods. The knowledge of the mechanism of attack will lead to future benefits in designing fuel cells resistant to such attacks.

Mercury vapor, also known to be present in coal syngas, may also cause degradation of cell performance. This is not expected to occur, but along with sophisticated analytical techniques, this testing will prove that mercury vapor is reaching the SOFC anode and determining whether it is depressing cell performance. Very few researchers have studied the effects of higher hydrocarbons and mercury. Testing these trace species provides an additional contribution to the literature for future consideration of the cleanup of these materials. By cleaning coal syngas as little as possible, money and other resources can be saved compared to an exhaustive syngas cleanup train. 


\section{CHAPTER TWO - LITERATURE REVIEW}

Described below in this chapter are: the scope of the problem in considering syngas as a fuel, coal gasification, a thermodynamic analysis as a basis for generating a primary list of elements to be considered in anode interaction studies, and SOFC operation in the presence of elements expected in direct syngas. The main body of the review focuses on the current state of research from numerous institutions on trace contaminants in coal and their interaction with nickel-based SOFC anodes from various manufacturers.

\subsection{Technology Background}

\subsubsection{Syngas as a Fuel for SOFCs}

Gasification is a process that converts a carbon and hydrogen-containing material (e.g. coal and biomass) into primarily carbon monoxide and hydrogen. In coal gasification, coal is fed to a pressure vessel where it reacts with steam and oxygen at high temperature $\left(500-1800^{\circ} \mathrm{C}\right)$ and pressure $(25-70 \mathrm{~atm})$ in an oxygen lean environment ${ }^{13}$. Table 2.1 describes the syngas bulk composition produced from several combinations of gasifiers and coal types. 
Table 2.1 - Syngas composition from different gasifiers ${ }^{17}$

\begin{tabular}{|c|c|c|c|c|c|}
\hline $\begin{array}{c}\text { Gasifier } \\
\text { Type }\end{array}$ & $\begin{array}{c}\text { Fluidized } \\
\text { Bed }\end{array}$ & \multicolumn{4}{|c|}{ Entrained Bed } \\
\hline Manufacturer & Winkler & Destec & $\begin{array}{c}\text { Koppers- } \\
\text { Totzek }\end{array}$ & Texaco & Shell \\
\hline Coal & $\begin{array}{c}\text { Texas } \\
\text { Lignite }\end{array}$ & $\begin{array}{c}\text { Appalachian } \\
\text { Bituminous }\end{array}$ & Illinois \#6 & Illinois \#6 & Illinois \#6 \\
\hline Mole \% & & & & & \\
\hline $\mathrm{Ar}$ & 0.7 & 0.8 & 0.9 & 0.9 & 1.1 \\
\hline $\mathrm{CH}$ & 4.6 & 0.6 & 0.0 & 0.1 & 0.0 \\
\hline $\mathrm{CO}$ & 33.1 & 45.2 & 43.8 & 39.6 & 63.1 \\
\hline $\mathrm{CO} 2$ & 15.5 & 8.0 & 4.6 & 10.8 & 1.5 \\
\hline $\mathrm{COS}$ & 0.0 & 0.0 & 0.1 & 0.0 & 0.1 \\
\hline $\mathrm{H}_{2}$ & 28.3 & 33.9 & 21.1 & 30.3 & 26.7 \\
\hline $\mathrm{H}_{2} \mathrm{O}$ & 16.8 & 9.8 & 27.5 & 16.5 & 2.0 \\
\hline $\mathrm{H}_{2} \mathrm{~S}$ & 0.2 & 0.9 & 1.1 & 1.0 & 1.3 \\
\hline $\mathrm{N}_{2}$ & 0.6 & 0.6 & 0.9 & 0.7 & 4.1 \\
\hline $\mathrm{NH}_{3}+\mathrm{HCN}$ & 0.1 & 0.2 & 0.0 & 0.0 & 0.0 \\
\hline $\mathrm{Total}$ & 100 & 100 & 100 & 100 & 100 \\
\hline
\end{tabular}

Coal gasifier designs in use with SOFC technology include transport reactors, entrained flow reactors, and advanced catalytic gasifiers. In a transport gasifier reactor, coal and oxygen are injected into a circulating fluidized bed, which transports pulverized coal between a particulate removing cyclone and the reaction chamber. The transport gasifier operates at a comparatively low temperature and with reduced energy consumption due to particulate matter recycling. Entrained flow gasification is characterized by mixing finely pulverized coal with oxygen and rapid reaction due to the high temperature of the system. The entrained flow gasifier operates at higher pressure and throughput ${ }^{4,18}$. This system is commonly used in integrated gasification combined cycle (IGCC) plants such as Tampa Electric Company’s Polk Power Station, and is anticipated for future use with integrated gasification and fuel cell (IGFC) systems ${ }^{19}$.

Previous studies have concluded that syngas is a feasible fuel in SOFCs ${ }^{14,20}$. The proposed basic reactions taking place in a SOFC operating on clean syngas are ${ }^{12,21 .}$ 
Anode:

Electrochemical combustion of $\mathrm{H}_{2}$ :

$\mathrm{H}_{2}+\mathrm{O}^{2-} \rightarrow \mathrm{H}_{2} \mathrm{O}+2 e^{-}$

Electrochemical combustion of CO:

$\Delta \mathrm{H}\left(800^{\circ} \mathrm{C}\right)=-242 \mathrm{~kJ} / \mathrm{mol}$

Water-Gas Shift reaction:

$\mathrm{CO}+\mathrm{H}_{2} \mathrm{O} \leftrightarrow \mathrm{CO}_{2}+\mathrm{H}_{2}$

$\Delta \mathrm{H}\left(800^{\circ} \mathrm{C}\right)=-38.6 \mathrm{~kJ} / \mathrm{mol}$

Methane-Steam Reforming reaction: $\quad \mathrm{CH}_{4}+\mathrm{H}_{2} \mathrm{O} \leftrightarrow \mathrm{CO}+3 \mathrm{H}_{2}$ $\Delta \mathrm{H}\left(800^{\circ} \mathrm{C}\right)=+242 \mathrm{~kJ} / \mathrm{mol}$

Methane/ $\mathrm{CO}_{2}$ Reforming reaction:

$$
\begin{gathered}
\mathrm{CH}_{4}+\mathrm{CO}_{2} \leftrightarrow 2 \mathrm{H}_{2}+2 \mathrm{CO} \\
\Delta \mathrm{H}\left(800^{\circ} \mathrm{C}\right)=+203 \mathrm{~kJ} / \mathrm{mol}
\end{gathered}
$$

Cathode:

Oxygen reduction:

$$
\begin{gathered}
\mathrm{O}_{2}+4 e^{-} \rightarrow 2 \mathrm{O}^{2-} \\
\Delta \mathrm{H}\left(800^{\circ} \mathrm{C}\right)=0 \mathrm{~kJ} / \mathrm{mol}
\end{gathered}
$$

Net Electrochemical Reaction:

$$
\begin{gathered}
\mathrm{O}_{2}+\mathrm{CO}+\mathrm{H}_{2} \rightarrow \mathrm{CO}_{2}+\mathrm{H}_{2} \mathrm{O} \\
\Delta \mathrm{H}\left(800^{\circ} \mathrm{C}\right)=-431 \mathrm{~kJ} / \mathrm{mol}
\end{gathered}
$$

The methane in syngas, coupled with the presence of nickel in the anode and the high SOFC operating temperatures, results in favorable conditions for the methane-steam reforming (MSR) reaction, as shown in Equation 2.4. In addition, carbon monoxide reacts with steam to produce hydrogen via the water-gas shift (WGS) reaction, as shown in Equation 2.3. The hydrogen that is produced in these reactions, as well as that already present in the coal syngas, is electrochemically oxidized as shown in Equation 2.1.

The formation of solid carbon (coking) on the anode surface can limit the performance of a SOFC. Such coking can be prevented by including a sufficient amount of steam to drive the WGS reaction toward $\mathrm{CO}_{2}$. Water can also gasify the carbon as shown in Equation 2.8. The 
formation of carbon is due primarily to the Boudouard reaction, which is shown in Equation $2.9^{22}$.

$$
\begin{array}{rr}
\mathrm{C}+\mathrm{H}_{2} \mathrm{O} \rightarrow \mathrm{CO}+\mathrm{H}_{2} & \Delta \mathrm{H}\left(800^{\circ} \mathrm{C}\right)=-189 \mathrm{~kJ} / \mathrm{mol} \\
2 \mathrm{CO} \rightarrow \mathrm{C}+\mathrm{CO}_{2} & \Delta \mathrm{H}\left(800^{\circ} \mathrm{C}\right)=-189 \mathrm{~kJ} / \mathrm{mol}
\end{array}
$$

Equations 2.1-2.9 only describe the "basic reaction steps" involving the bulk gas and oxygen ions. Reaction mechanisms describing the reaction of trace species in coal gasification are not presently described in the literature. The specific trace specie interactions and reaction mechanisms are likely to be sensitive to the bulk gas composition. For example, thermodynamic calculations have shown that formation of secondary $\mathrm{Ni}_{\mathrm{x}} \mathrm{S}_{\mathrm{y}}$ phases is sensitive to the fuel composition $^{15}$, and surface phases may be produced that interact with other trace and bulk gas species. Competition for reactive surface sites and electrochemically active TPB sites will also be affected by the bulk gas matrix.

The effect of trace species in coal syngas on SOFC performance is not completely understood. Investigations are underway to discover how these species will react with the anode in the fuel cell environment. The effect of sulfur $\left(\mathrm{H}_{2} \mathrm{~S}\right)$ and chlorine $(\mathrm{HCl})$ on the system has been documented in the literature ${ }^{23,24}$, and some mitigation techniques ${ }^{4,25}$ have already been proposed. Information on previously investigated trace species/anode studies is reported in Section 2.2. 


\subsubsection{SOFCs Operating on Simulated Clean Syngas}

Suwanwarangkul et al. ${ }^{22}$ have developed a system model of a SOFC operating on coal syngas to predict SOFC performance for various operating conditions, including composition of the fuel. The species considered in this model include $\mathrm{H}_{2}, \mathrm{CO}, \mathrm{CO}_{2}, \mathrm{H}_{2} \mathrm{O}$, and $\mathrm{N}_{2}$. The results show that based on the model, lower fuel cell performance is expected when the SOFC is operated on syngas. The major effect is likely due to the carbon formation by the Boudouard reaction (Equation 2.9) that damages the anode surface. In addition, there is a lower cell potential for fuel cells operating on syngas as opposed to hydrogen with $3 \%$ humidification. The results also show that the open circuit potential (OCV) obtained using the mixed syngas is lower than the other mixtures that did not contain $\mathrm{CO}_{2}$. This is expected because of the WGS reaction occurs in the presence of $\mathrm{CO}_{2}$.

Gemmen and Trembly ${ }^{26}$ investigated the transport of coal-derived syngas through the anode of an SOFC using a porous media model. They focused on the inlet edge of the anode because any chemical non-equilibrium of the anode gas will cause significant heating or cooling as the nickel anode material catalytically converts the gases via the endothermic MSR reaction and the exothermic WGS reaction. They also assessed carbon deposition on the anode surface using thermodynamic equilibrium analysis software. Results showed that carbon deposition became close to thermodynamically possible as pressures approached $10 \mathrm{~atm}$, but are still outside the deposition region. A further result was that above a maximum pressure of $8 \mathrm{~atm}$, methane will be produced from hydrogen. The WGS reaction rate was shown to increase up to about 7 atm, while operating at higher pressures reduced the shift of $\mathrm{CO}$ to $\mathrm{H}_{2}$. Finally, the overpotential due to hydrogen diffusion losses shows a decrease in value as pressure increases up to about 5 atm after which diffusion losses again increase. 
Colpan et al. ${ }^{27}$ performed a thermodynamic model of direct internal reforming in a SOFC using coal syngas as fuel feed. They showed that the recirculation ratio of the anode exit stream does not have a significant effect for low current density conditions. At higher current densities, increasing the recirculation ratio decreases the power output and electrical efficiency of the cell. The results show that high fuel utilization conditions result in low power output and air utilization but higher electrical efficiency of the cell.

Laurencin et al. ${ }^{21}$ developed a model to study the thermal and electrochemical behavior of a SOFC stack fueled directly with methane. The group used Ni-YSZ as the anode material. They found that methane reforming into hydrogen is confined to the cell inlet, and therefore, a sufficient anode thickness (larger than $400-500 \mu \mathrm{m}$ ) is required for efficient conversion. The best electrochemical/thermal trade-off point of operation was found to be between $40-55 \%$ fuel conversion.

\subsubsection{Gas Cleanup}

Descriptions of gas cleanup processes and trace element movement through the IGFC system are critical to understanding the exposure of the SOFC anode to trace syngas species. In current gasification applications, process gas exits the gasifier and undergoes gas quenching, particulate removal, and gas polishing (via sorbent systems). Particulates are removed using filtration or collection devices such as traps and cyclones. Sulfur is traditionally removed using low temperature quenching and wet scrubbing processes, although recent research has been pursuing the use of warm/hot gas sorbents. The primary targeted species for conventional cleanup are sulfur and halides mainly because of environmental regulations. More recently, mercury has also been regulated. ${ }^{28,29}$ 
Gas exiting the coal gasifier can be cleaned of hazardous materials by several methods. Particulate Collection Devices (PCDs) such as baghouse filters and ceramic candle filters are effective at reducing particulate loadings to around 1-20 $\mathrm{ppm}^{30,31}$. PCD installations offer particulate removal at temperatures of $400-510^{\circ} \mathrm{C}$ by means of sintered metal or ceramic filters ${ }^{15}$. The high operating temperature is beneficial for IGFC systems with regard to thermodynamic efficiency, but trace elements that would normally partition to the trapped particulates at lower temperatures can remain volatile and travel to the fuel cell anode.

Low temperature adsorption systems remove of $\mathrm{H}_{2} \mathrm{~S}$, halide species, and ammonia. ${ }^{4}$ Specifically, zinc ferrite $\left(\mathrm{ZnFeO}_{4}\right)$ sorbents are used for sulfur removal because of their favorable adsorption performance. Zinc ferrite systems reduce sulfur loading below $10 \mathrm{ppm}$ down from 100-300 $\mathrm{ppm}^{30}$. Although these methods are efficient in removing $\mathrm{H}_{2} \mathrm{~S}$ and halide species down to less than $1 \mathrm{ppm}$, they are not beneficial to the overall thermodynamic efficiency, due to a significant loss of thermal energy resulting from ambient temperature operation ${ }^{16}$. The United States Department of Energy (USDOE) is currently developing warm gas cleanup systems that will remove $\mathrm{H}_{2} \mathrm{~S}, \mathrm{HCl}, \mathrm{HCN}$, particulate matter, and alkali species at temperatures of 250$500^{\circ} \mathrm{C}^{32}$. Hot gas cleanup sorbents have also received heavy attention recently $\mathrm{y}^{33,34,35,36,37}$ from researchers interested in sulfur removal.

At the end of 2007, the EPA made a regulatory decision that mercury emissions need to be controlled, with all plants required to be in full compliance. On average $60 \%$ of mercury entering a coal-fired power plant is emitted. ${ }^{29}$ Current mercury cleanup techniques include capture in the boiler, PCDs, scrubbers, spray dryer adsorbers, fabric filters, and selective catalytic reduction. 
Higher cleanup temperatures increase the probability of trace species passing through the system. ${ }^{4}$ Eleven trace elements found in coal are considered hazardous air pollutants by the 1990 Clean Air Act Amendments: Sb, As, Be, Cd, Pb, Hg, Mo, Se, Cr, V, and $\mathrm{Zn}^{31}$. These elements can be volatilized during the gasification process and are likely present in syngas fuel streams in trace amounts ${ }^{16}$. Thermodynamic evaluations have shown that $\mathrm{Sb}, \mathrm{As}, \mathrm{Cd}, \mathrm{Pb}, \mathrm{Hg}$, P, and Se will form a vapor phase in coal syngas during warm gas cleanup, and therefore, will possibly form solid secondary phases with the anode material. More specifically, Sb, As, and P were shown by thermodynamic analysis to form stable secondary phases with $\mathrm{Ni}$ in the SOFC anode ${ }^{16}$. Table 2.2 is a summary of a trace species analysis conducted on the gasification stream of the Eastman Chemical Company’s system at Kingsport.

Table 2.2 - Trace elements and their concentration in coal syngas as reported at the Kingsport Facility ${ }^{38}$

\begin{tabular}{|c|c|}
\hline Trace Specie & $\begin{array}{c}\text { Concentration } \\
\text { (ppmv) }\end{array}$ \\
\hline $\mathrm{As}\left(\mathrm{AsH}_{3}\right)$ & $0.15-0.58$ \\
\hline $\mathrm{CH}_{3} \mathrm{~F}$ & 2.60 \\
\hline $\mathrm{CH}_{3} \mathrm{Cl}$ & 2.01 \\
\hline $\mathrm{HCl}$ & $<1.0$ \\
\hline $\mathrm{Fe}(\mathrm{CO})_{5}$ & $0.05-5.60$ \\
\hline $\mathrm{Ni}(\mathrm{CO})_{5}$ & $0.001-0.025$ \\
\hline $\mathrm{CH} \mathrm{HCN}_{3}$ & 2.1 \\
\hline $\mathrm{PH}$ & 1.9 \\
\hline $\mathrm{Sb}$ & 0.025 \\
\hline $\mathrm{Cd}$ & $<0.010$ \\
\hline $\mathrm{Cr}$ & $<0.025$ \\
\hline $\mathrm{Hg}$ & $<0.025$ \\
\hline $\mathrm{Se}$ & $<0.150$ \\
\hline $\mathrm{V}$ & $<0.025$ \\
\hline $\mathrm{Pb}$ & $\mathrm{NA}$ \\
\hline $\mathrm{Zn}$ & 9.0 \\
\hline & \\
\hline & \\
\hline
\end{tabular}


Solid elements have been categorized by volatility class ${ }^{39}$ which describes their tendency to condense. Ash and metals are converted into an inert, coarse, sand-like material called slag, which is subsequently removed via the PCDs. Some inorganic material is postulated to form vapor phase species and are likely present in the syngas stream in trace amounts ${ }^{18}$. According to the volatility classification, Group $1^{*}$ elements of this classification (e.g. Ba, Ce, Cs, Mg, Mn, and Th) generally partition exclusively to the ash and slag phases. These elements are trapped by particulate control systems and are not considered part of the final syngas stream. Volatility Class Group 2 elements (e.g. As, $\mathrm{Cd}, \mathrm{Cu}, \mathrm{Pb}, \mathrm{Sb}, \mathrm{Se}, \mathrm{Zn}$ ) are concentrated more in the particulates than the ash or slag. They are also enriched on the fine-grained particles, which may escape the particulate control systems. Volatility Class Group 3 elements (e.g. $\mathrm{Br}, \mathrm{Cl}, \mathrm{Hg}$ ) volatilize readily. They are concentrated in the vapor or gas phase and are depleted in all solid phases. Also, some elements, such as $\mathrm{Cr}, \mathrm{Ni}, \mathrm{U}$, and $\mathrm{V}$, may show partitioning behavior intermediate between Groups 1 and 2, while volatile elements, such as Se and I may show partitioning behavior intermediate between Groups 2 and 3.

\subsubsection{SOFCs Operating on Direct Coal Syngas}

There has been little work demonstrating the performance of a SOFC on direct coal syngas. Most research has focused on feasibility and modeling of such a process. The Delphi Corporation is one group that has tested a SOFC on direct coal syngas ${ }^{14}$. The group tested a SOFC on the coal gasifier at the Power Systems and Development Facility (PSDF) in Wilsonville, AL. Syngas passed through a cleanup train to remove sulfur, chlorine, and tar impurities from the stream before entering the fuel cell stack. The Delphi SOFC operated at $750^{\circ} \mathrm{C}$, and the cells operated for about $75 \mathrm{~h}$.

\footnotetext{
* These groups are not to be confused with elemental groups of the periodic table.
} 
Kivisaari et al. ${ }^{12}$ investigated the feasibility of integrating a 50 MW fuel cell system with an existing network for heat and power distribution. The final system, which included an entrained flow gasifier combined with standard low-temperature gas cleanup and SOFC, resulted in an overall electrical efficiency of $47 \%$, and an overall efficiency close to $85 \%$. The group compared two fuel cell technologies, and deemed SOFCs more technologically and economically feasible than the molten carbonate fuel cell (MCFC) alternative. The group used a Pittsburgh No. 8 coal, which was finely ground prior to feeding into the Prenflo gasifier (manufactured by Krupp Uhde).

When the simulations of their coal-fired combined heat and SOFC power system code (with a thermal input of $50 \mathrm{MW}$ ) named "BARAKA," standing for the investigators initials are compared to existing power generation techniques, the hybrid system is able to outperform both Integrated Gasification Combined Cycle (IGCC) and pressurized fluidized bed combustion (PFBC), as shown in Table 2.3.

Table 2.3 - Comparison of Different Power Generation Techniques ${ }^{12}$

\begin{tabular}{|l|l|l|l|}
\hline & BARAKA & IGCC & PFBC \\
\hline Unit size $\left(\mathrm{MW}_{\mathrm{e}}\right)$ & 23.4 & 262 & 70 \\
\hline Electrical efficiency (\% HHV) & 45.1 & 39.7 & 33.2 \\
\hline $\mathrm{SO}_{2}(\mathrm{~g} / \mathrm{MWh})$ & 0.7 & 612.4 & 774.5 \\
\hline $\mathrm{NO}_{x}(\mathrm{~g} / \mathrm{MWh})$ & 133.6 & 494.4 & 288.0 \\
\hline
\end{tabular}

\subsection{The Effect of Coal Syngas Trace Species on SOFC Performance}

SOFC anodes are typically made from Ni-YSZ ceramics, so only nickel-based electrodes are considered in this review. Anodes so comprised are shown to be good catalysts for hydrogen oxidation and good electronic conductors while providing some ionic conductivity and good 
thermo-mechanical properties. When operating a Ni-YSZ anode on hydrogen fuel at $800^{\circ} \mathrm{C}$ using current planar technology, a maximum power density of around $1 \mathrm{~W} / \mathrm{cm}^{2}$ is achievable ${ }^{40}$. Trace species have been shown to interact with the nickel anode to depress cell performance. The following section outlines the published work for each system ${ }^{15,16,18,22-24,26,38,41-56}$.

The descriptions for each element in this section are arranged in the same pattern when information is available. Background information is presented first followed by theoretical or computational results including thermodynamic predictions and adsorption estimates derived from density functional theory (DFT) calculations. Experimental methods are then outlined and describe the conditions of operation (temperature, pressure, gas composition, potential/current of operation, etc.), the relevant experimental results, and the spectroscopic analysis performed on the SOFC sample. Finally, general trends are identified, if possible. The order of presentation is by group (period) from the periodic table. This is done because of the similarity in attack mechanisms for elements within the same grouping.

\subsubsection{Group VI ${ }^{*}$ Element - Sulfur (S)}

Sulfur is abundant in coal syngas (100-300 ppm) relative to other trace inorganic species, and typically exists as $\mathrm{H}_{2} \mathrm{~S}$ in the reducing gasification environment. Although sulfur is not considered a trace element in coal, its interaction with SOFC anodes has been widely studied and provides a starting point for discussion of interactions with other trace species. Studies which discuss the effect of sulfur containing compounds (such as $\mathrm{H}_{2} \mathrm{~S}$ ) on the SOFC anode describe both adsorptive and reactive processes ${ }^{20,43,44,57}$. No clearly defined mechanism is available due to the lack of detailed experimental data ${ }^{43}$, but general aspects of the interaction have been postulated.

\footnotetext{
${ }^{*}$ Category from the periodic table of the elements.
} 
Even at $\mathrm{H}_{2} \mathrm{~S}$ concentrations below $100 \mathrm{ppm}$, density functional theory calculations predict favorable adsorption of $\mathrm{H}_{2} \mathrm{~S}$ onto the anode surface, reducing active surface area and causing a subsequent loss in cell performance ${ }^{46,58,59}$. The adsorbed sulfur is more stable on the surface at lower temperatures and lower hydrogen concentrations ${ }^{58}$, as shown in Figure 2.1. Possible overall adsorption processes are described in Equations 2.10, 2.11 and 2.12 ${ }^{46}$.

$$
\begin{gathered}
\mathrm{Ni}(\mathrm{s})+\mathrm{S}(\mathrm{g}) \rightarrow \mathrm{S}(\mathrm{Ni}) \\
\mathrm{Ni}+\mathrm{H}_{2} \mathrm{~S} \rightarrow \mathrm{NiSH}_{2} \rightarrow \mathrm{NiSH}+\mathrm{H} \rightarrow \mathrm{NiS}+\mathrm{H}_{2} \\
\mathrm{Ni}+\mathrm{H}_{2} \mathrm{~S} \rightarrow \mathrm{NiSH}^{*}+\mathrm{H} \rightarrow \mathrm{NiS}+\mathrm{H}_{2}
\end{gathered}
$$

Equation 2.11 represents molecular adsorption and Equation 2.12 represents dissociative adsorption which is energetically more favorable ${ }^{46}$ considering Gibbs free energies of formation.

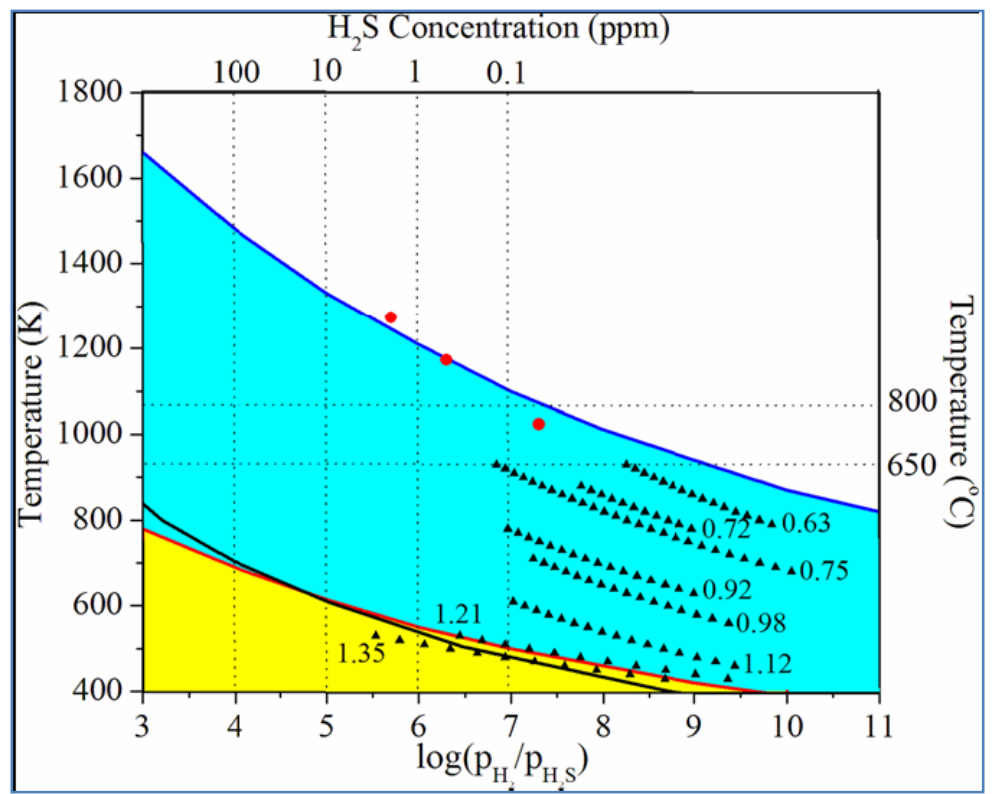

Figure 2.1 - Calculated Ni-S phase diagram. The upper region is the predicted clean Ni surface phase, the middle region represents the absorbed sulfur atoms on $\mathrm{Ni}$ surface phases and the lower region is the $\mathrm{Ni}_{2} \mathrm{~S}_{3}$ bulk phase. $^{58}$ 
Thermodynamic calculations show that bulk $\mathrm{Ni}_{x} \mathrm{~S}_{y}$ phases are prevalent for $\mathrm{H}_{2} \mathrm{~S}$ exposure greater than $100 \mathrm{ppm}$ at lower operating temperatures for a range of bulk gas (CO, $\mathrm{CO}_{2}, \mathrm{H}_{2} \mathrm{O}$, $\mathrm{H}_{2}$ ) compositions ${ }^{15}$. At $600^{\circ} \mathrm{C}$, the lower $\mathrm{H}_{2} \mathrm{~S}$ exposure threshold required to generate a stable secondary phase is $140 \mathrm{ppm}$, while at $800^{\circ} \mathrm{C}$ the exposure approaches $1000 \mathrm{ppm}$. Ni-S phase formation reactions are shown in Equations 2.13 and 2.14.

$$
\begin{array}{r}
\mathrm{Ni}(s)+S(g) \rightarrow \mathrm{NiS}(s) \\
3 \mathrm{Ni}(s)+2 S(g) \rightarrow \mathrm{Ni}_{3} \mathrm{~S}_{2}(s)
\end{array}
$$

Sulfur exposure experiments have been conducted by several groups for fuel cell systems. Matsuzaki et al. ${ }^{43}$ exposed anodes to a fuel $\left(\mathrm{H}_{2}-79 \% / \mathrm{H}_{2} \mathrm{O}-21 \%\right)$ containing $\mathrm{H}_{2} \mathrm{~S}$ at several levels less than $15 \mathrm{ppm}$ under galvanostatic conditions of $0.3 \mathrm{~A} / \mathrm{cm}^{2}$ and at temperatures between $750^{\circ} \mathrm{C}$ and $1000^{\circ} \mathrm{C}$. Zha et al. ${ }^{55}$ operated cells in a fuel $\left(\mathrm{H}_{2}-50 \% / \mathrm{H}_{2} \mathrm{O}-1.5 \% / \mathrm{N}_{2}-48.5 \%\right)$ containing $\mathrm{H}_{2} \mathrm{~S}$ at levels less than 50 ppm under potentiostatic conditions between 0.6 and $0.7 \mathrm{~V}$ and at temperatures between $700^{\circ} \mathrm{C}$ and $900^{\circ} \mathrm{C}$. Sasaki et al. ${ }^{56}$ operated cells in a fuel $\left(\mathrm{H}_{2}-97 \%\right.$ / $\mathrm{H}_{2} \mathrm{O}$ - 3\%) containing $\mathrm{H}_{2} \mathrm{~S}$ at several levels less than 200 ppm under galvanostatic conditions of $0.2 \mathrm{~A} / \mathrm{cm}^{2}$ and at temperatures between $850^{\circ} \mathrm{C}$ and $1000^{\circ} \mathrm{C}$. Lussier et al. ${ }^{45}$ exposed anodes to a fuel ( $\mathrm{H}_{2}-43 \%$ / $\left.\mathrm{N}_{2}-57 \%\right)$ containing $\mathrm{H}_{2} \mathrm{~S}$ at levels between $100 \mathrm{ppm}$ and 1500 ppm under potentiostatic conditions of $0.5 \mathrm{~V}$ and at a temperature of $750^{\circ} \mathrm{C}$.

Experiments performed by Zha et al., Sasaki et al., and Lussier et al., each demonstrated a sharp depression of the power output within 30 seconds of sulfur exposure followed by up to 200 seconds of slower, continued output depression. The adsorbed sulfur can be removed from the anode by exposure to pure hydrogen, provided that the sulfur exposure was of short duration and 
low concentration ${ }^{43}$. Once the $\mathrm{H}_{2} \mathrm{~S}$ exposure is interrupted, the performance increases sharply within 30 seconds followed by a more gradual increase lasting from $20 \mathrm{~min}$ to $3000 \mathrm{~min}$ as the original operating output is approached. If $\mathrm{H}_{2} \mathrm{~S}$ exposure was long in duration or if concentrations above $100 \mathrm{ppm}$ were imposed, secondary phases begin to form and full cell output recovery cannot be achieved ${ }^{15,45}$. In an extreme case, Lussier et al. observed migration of nickel within the cell.

Experiments performed by Matsuzaki et al. described the electrode polarization as a function of operating temperature and exposure. The polarization and overpotential increased when the $\mathrm{H}_{2} \mathrm{~S}$ concentration exceeded $0.05,0.5$, and $2 \mathrm{ppm}$ at 750,900 , and $1000^{\circ} \mathrm{C}$, respectively. Recovery durations over seven times longer than exposure durations were required to reverse the polarization completely. Therefore, at lower operating temperatures, high-grade desulfurization is necessary to maintain cell operation.

Processes at the TPB may also mitigate sulfur interaction in the anode. In their discussion of deviations in the power output as a function of galvanostatic or potentiostatic test conditions, Cheng et al. ${ }^{23}$ reported that upon exposure to $\mathrm{H}_{2} \mathrm{~S}$, increases in total cell internal resistance appear to be lower when more current is drawn from the cell. This is similarly expressed by Zha et al. ${ }^{55}$, who showed that cells operated at higher current density tend to show greater resistance to $\mathrm{H}_{2} \mathrm{~S}$ as measured by cell current density during exposure. It was postulated that the adsorbed sulfur could be electrochemically oxidized by oxygen atoms at the triple phase boundary into $\mathrm{SO}_{2}$ as follows:

$$
S_{(a d)}+2 O^{2-} \leftrightarrow S O_{2}+4 e^{-}
$$


In-situ Raman spectroscopy was applied to sulfur adsorption by Cheng et al. ${ }^{60}$ and Dong et al. ${ }^{61}$. In both studies, Ni-YSZ samples were exposed to $\mathrm{H}_{2} \mathrm{~S}$ at temperatures between 500 and $800^{\circ} \mathrm{C}$, but with no electrochemical load. Surface species were detectable at temperatures below $500^{\circ} \mathrm{C}$ or for $\mathrm{H}_{2} \mathrm{~S}$ concentrations of greater than $10 \%$, but surface species could not be detected at temperatures above $500^{\circ} \mathrm{C}$ when the $\mathrm{H}_{2} \mathrm{~S}$ concentration was below $100 \mathrm{ppm}$. When surface $\mathrm{Ni}_{\mathrm{X}} \mathrm{S}_{\mathrm{y}}$ species were detected with the Raman technique, no such species were detectable with $\mathrm{X}$ ray Diffraction (XRD), which is less sensitive to surface specific structures.

To summarize, sulfur appears capable of degrading cell output via: 1) surface adsorption on the anode surface of the nickel; 2) hindrance of the electrochemical oxidation reactions at the TPB; and 3) generation of a surface or bulk $\mathrm{Ni}_{\mathrm{x}} \mathrm{S}_{\mathrm{y}}$ phase. In addition to pure blocking methods, there may also be an electrostatic repulsion due to the surface adsorbed electronegative sulfur atoms. ${ }^{58}$ In general, $\mathrm{Ni}_{\mathrm{x}} \mathrm{S}_{\mathrm{y}}$ phases will not form at temperatures above $600^{\circ} \mathrm{C}$ for $\mathrm{H}_{2} \mathrm{~S}$ concentrations below $100 \mathrm{ppm}$ and for relatively short exposure times. Output degradation that is observed within these limitations is reversible, although recovery can be expected to require up to $50 \mathrm{~h}$ depending on the cell operating current density.

\subsubsection{Group VI ${ }^{*}$ Element - Selenium (Se)}

Selenium is another Group VI element expected to be present in coal syngas, but it has a larger atomic radius than sulfur. Gerdes et al. ${ }^{47}$ investigated the performance of anode-supported SOFCs operating in simulated syngas $\left(\mathrm{H}_{2}-29 \%\right.$ / $\left.\mathrm{CO}-29 \% / \mathrm{CO}_{2}-12 \% / \mathrm{N}_{2}-3 \% / \mathrm{H}_{2} \mathrm{O}-27 \%\right)$ containing selenium at 0.5 and $5 \mathrm{ppm}$ under galvanostatic conditions of $0.25 \mathrm{~A} / \mathrm{cm}^{2}$ and at $800^{\circ} \mathrm{C}$.

\footnotetext{
${ }^{*}$ Category from the periodic table of the elements.
} 


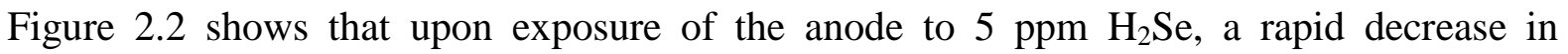
performance from $0.77 \mathrm{~V}$ to $0.72 \mathrm{~V}$ is recorded (Point 1). Following the initial drop, the cell continues to degrade at a rate of $0.0044 \mathrm{~V} / \mathrm{h}(610 \%$ per $1000 \mathrm{~h})$ for $23 \mathrm{~h}$ until it becomes steady at $0.61 \mathrm{~V}$. The steady-state potential output contains a noise band that is almost $150 \mathrm{mV}$ wide, most likely due to water condensation in the fuel supply line.

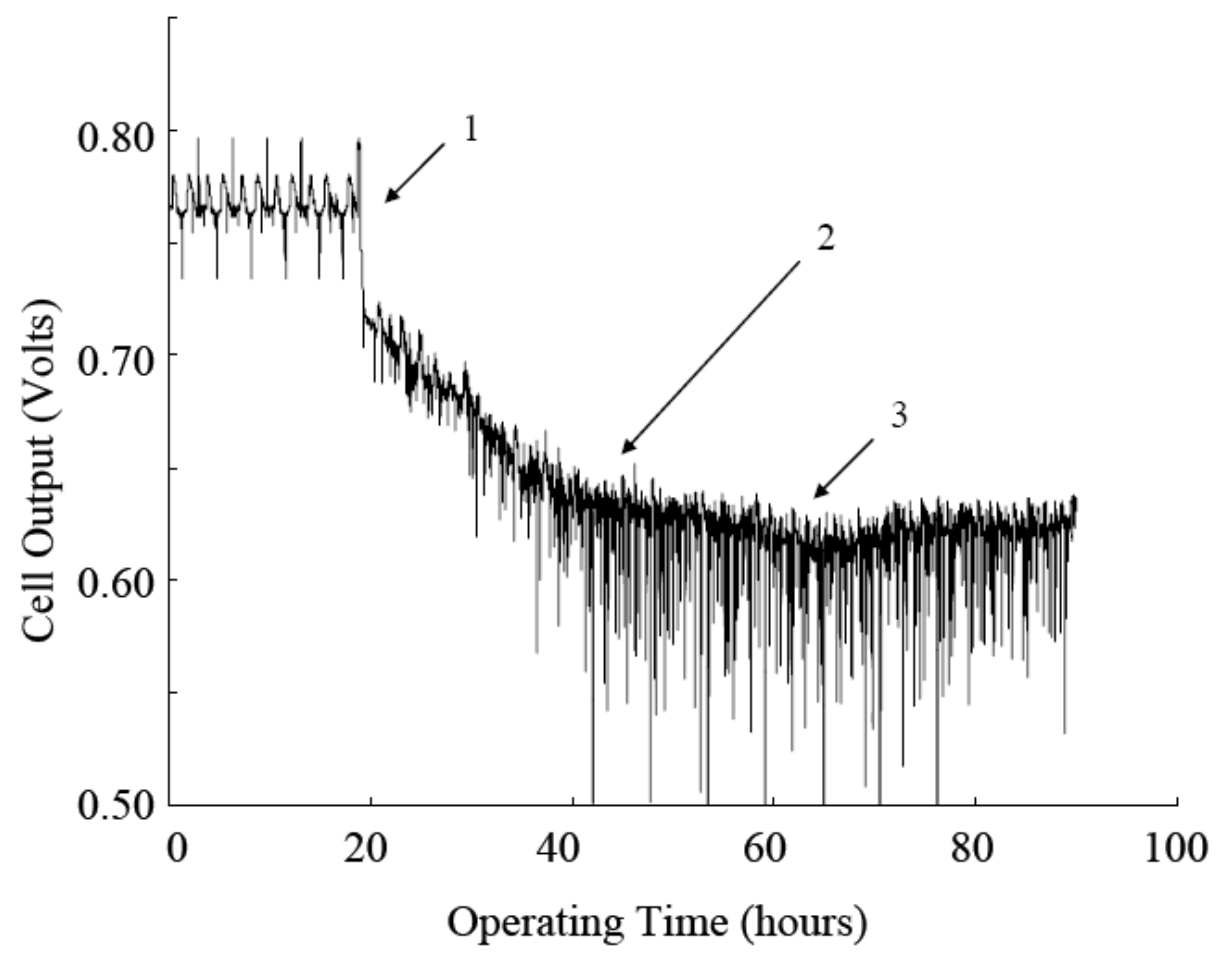

Figure 2.2 - Cell potential as a function of operating time for exposure to syngas containing 5 ppm $\mathrm{H}_{2} \mathrm{Se}$ at $800^{\circ} \mathrm{C}$ and $0.25 \mathrm{~A} / \mathrm{cm}^{247}$.

Figure 2.3 shows that the cell potential output upon exposure to syngas containing $0.5 \mathrm{ppm}$ Syngas is fed to the cell at Point 1 and $\mathrm{H}_{2}$ Se is introduced to the cell at Point 2. $\mathrm{H}_{2}$ Se does not produce a sharp initial decline. Following the $\mathrm{H}_{2}$ Se introduction, the cell degrades at a rate of $0.00047 \mathrm{~V} / \mathrm{h}(63 \%$ per $1000 \mathrm{~h}$ ) for $128 \mathrm{~h}$. A steady state potential of $0.68 \mathrm{~V}$ is reached (Point 4) and the system remains at this potential for the duration of the test (over 500 hours). Point 5 shows the period of the noise band while Point 6 was a fuel feed interruption. 


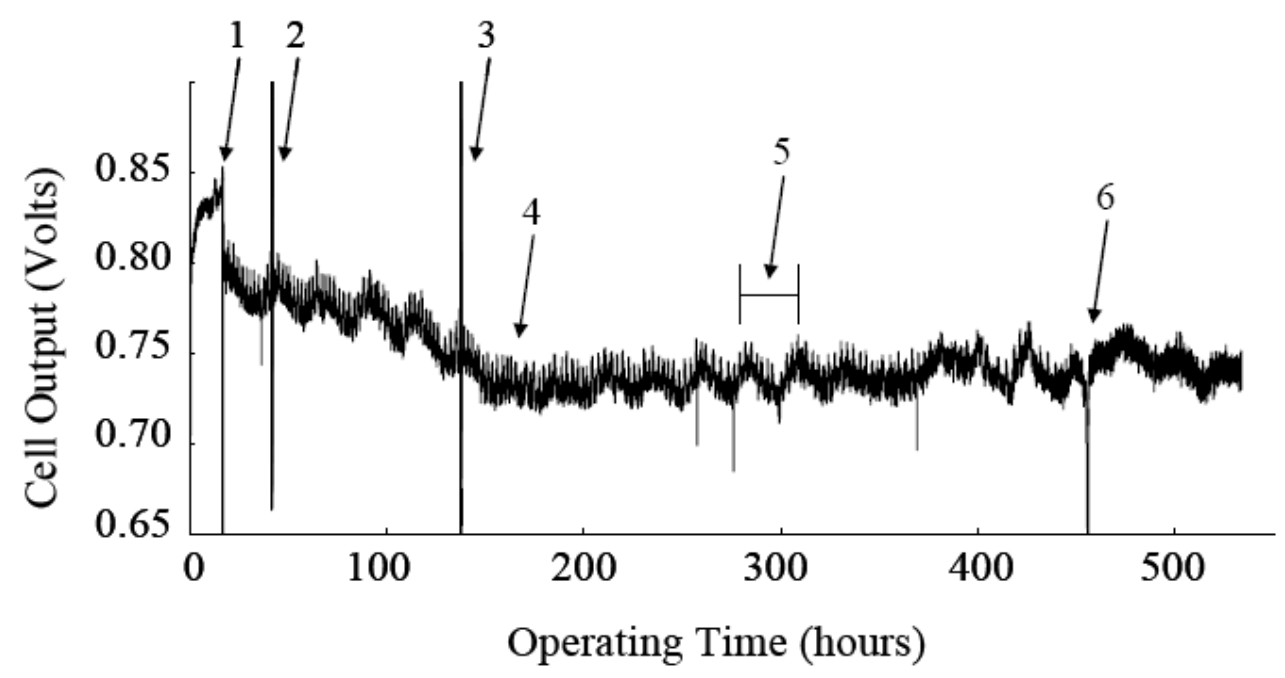

Figure 2.3 - Cell potential as a function of operating time for exposure to syngas containing $0.5 \mathrm{ppm} \mathrm{H}_{2} \mathrm{Se}$ at $800^{\circ} \mathrm{C}$ and $0.25 \mathrm{~A} / \mathrm{cm}^{2}{ }^{47}$.

A cyclic exposure test was also conducted in this study. The semi-chaotic potential output during $\mathrm{H}_{2} \mathrm{Se}$ exposure followed by partial potential recovery indicates that the observed degradation is not entirely the result of permanent mechanical failures within the cell. Because partial recovery was immediate upon re-exposure to hydrogen, it is implied that the behavior is not primarily due to the creation of secondary nickel selenide phases, as these are postulated to require a greater amount of time to be eliminated. Further, selenium phases are not predicted by thermodynamic analyses ${ }^{16}$, and are not expected. The partial recovery also indicates that not all degradation is reversible.

\subsubsection{Group VII ${ }^{*}$ Element - Chlorine (Cl)}

Hydrogen chloride $(\mathrm{HCl})$ is present in coal syngas in the range of 10 to $300 \mathrm{ppm}$. The overall equation for $\mathrm{NiCl}_{2}$ formation is:

$$
\mathrm{Ni}(s)+2 \mathrm{HCl}(\mathrm{g}) \rightarrow \mathrm{NiCl}_{2}(s)+\mathrm{H}_{2}(g)
$$

\footnotetext{
${ }^{*}$ Category from the periodic table of the elements.
} 
The Gibbs free energy change for the reaction is positive over the SOFC operating temperature range; therefore, $\mathrm{NiCl}_{2}$ formation is thermodynamically not feasible. However, at low levels, $\mathrm{HCl}$ can combine with elements such as iron, chromium, zinc, and lead to form volatile chloride species $^{38}$. Therefore, it is more likely that the presence of $\mathrm{HCl}$ affects the electrochemical processes of the SOFC anode through mechanisms other than secondary nickel phase formation.

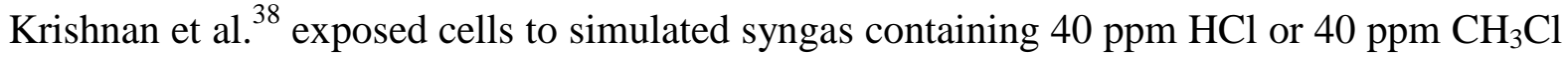
under galvanostatic conditions of $0.2 \mathrm{~A} / \mathrm{cm}^{2}$ at $750^{\circ} \mathrm{C}$ and $800^{\circ} \mathrm{C}$. Trembly et al. ${ }^{24}$ exposed LSM/SSZ/Ni-YSZ cells with a Ni-GDC interlayer to simulated syngas containing $\mathrm{HCl}$ at 20 and $160 \mathrm{ppm}$ under potentiostatic conditions of $0.7 \mathrm{~V}$ and at $800^{\circ} \mathrm{C}$ and $900^{\circ} \mathrm{C}$. Haga et al. ${ }^{62}$ exposed LSM/ScSZ/Ni-ScSZ cells to hydrogen gas doped with 5, 100, and $1000 \mathrm{ppm} \mathrm{Cl}_{2}$ under galvanostatic conditions of $0.2 \mathrm{~A} / \mathrm{cm}^{2}$.

Immediate degradation upon introduction of the $\mathrm{Cl}$ species was noted by Krishnan et al., although Trembly et al. report a sharp decrease in output lasting approximately 20 minutes. Both groups report steady degradation in performance following any initial degradation. Haga et al. reported linear degradation rates of $17 \%$ and $130 \%$ per $1000 \mathrm{~h}$ for $\mathrm{Cl}_{2}$ concentrations of 100 and $1000 \mathrm{ppm}$, respectively, but small degradation for $5 \mathrm{ppm}$ exposure. Krishnan et al. reported negligible performance degradation in the presence of $40 \mathrm{ppm} \mathrm{HCl}$ vapor for $100 \mathrm{~h}$, but degradation was observed at an unquantified rate for $\mathrm{CH}_{3} \mathrm{Cl}$. Trembly et al. reported that the degradation rate for the operational power density at $800^{\circ} \mathrm{C}$ increased from an initial value of $150 \%$ per $1000 \mathrm{~h}$ for $20 \mathrm{ppm}$ to $270 \%$ per $1000 \mathrm{~h}$ for $160 \mathrm{ppm}$. Figure 2.4 shows the timedependent power density at $800^{\circ} \mathrm{C}$. 


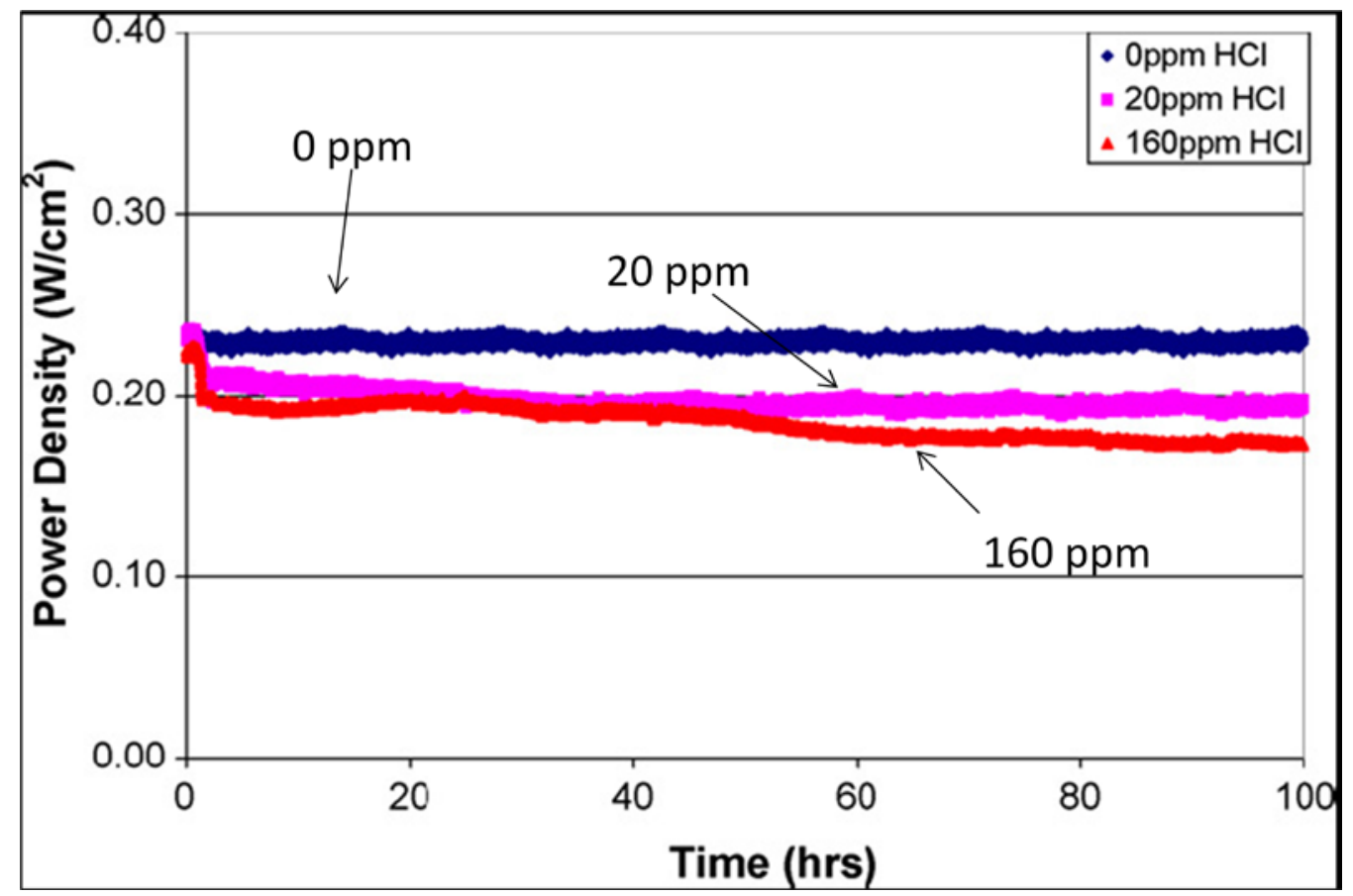

Figure 2.4 - SOFC power density operating at $800^{\circ} \mathrm{C}$ and $0.7 \mathrm{~V}$ over time with $\mathrm{HCl}$ concentrations of 0 , 20, and $160 \mathrm{ppm}^{24}$.

Trembly et al. also report data collected at $900^{\circ} \mathrm{C}$, reproduced in Figure 2.5. Initial operational power density of $0.392-0.420 \mathrm{~W} / \mathrm{cm}^{2}$ was observed. After $100 \mathrm{~h}$ of operation the current density degraded at a rate of $100 \%$ per $1000 \mathrm{~h}$ at $20 \mathrm{ppm}$ exposure and $530 \%$ per $1000 \mathrm{~h}$ at $160 \mathrm{ppm}$ exposure. The degradation rate is more rapid as temperature increases. 


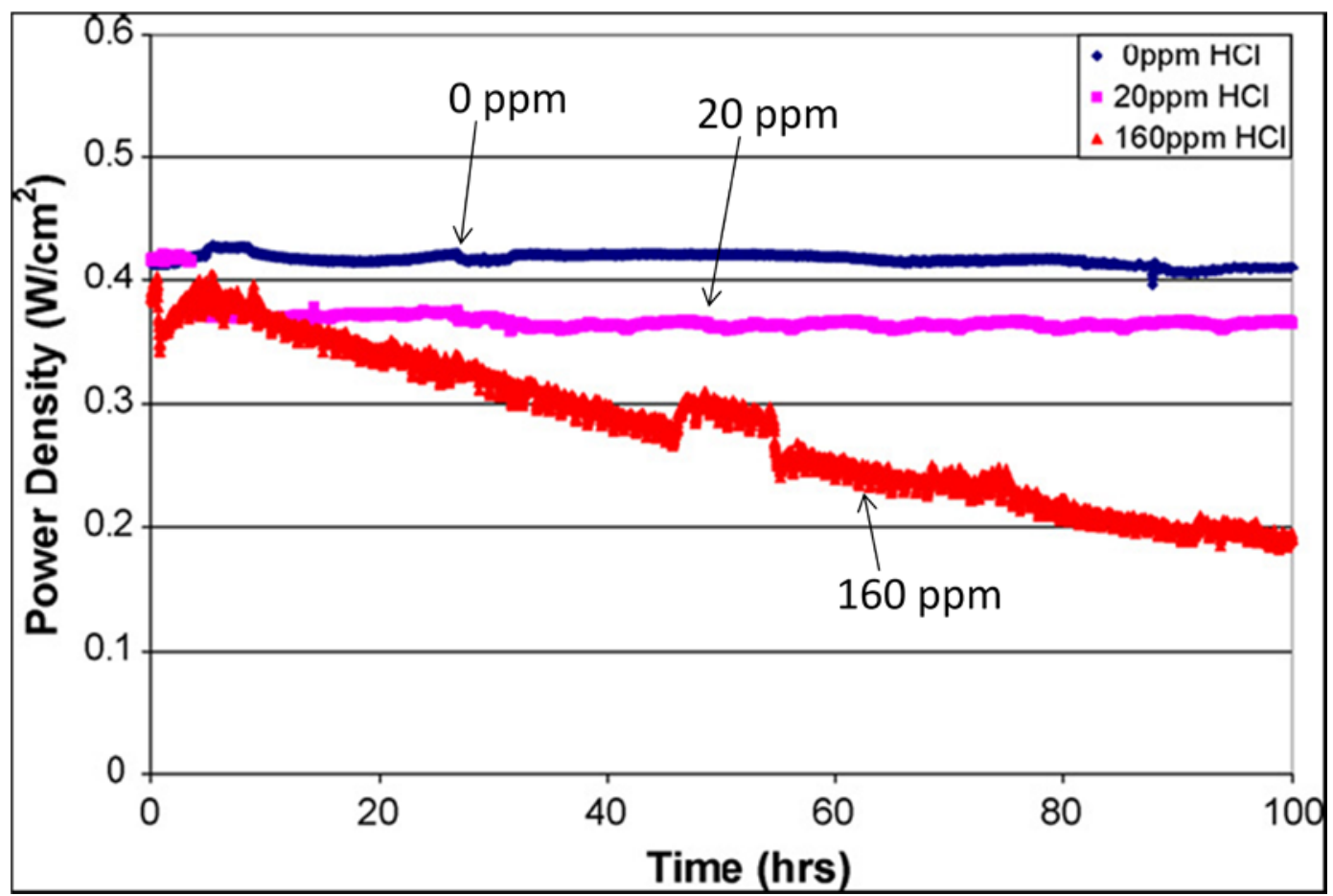

Figure 2.5 - SOFC power density curves at $900^{\circ} \mathrm{C}$ and $0.7 \mathrm{~V}$ over time with $\mathrm{HCl}$ concentrations of 0,20 , and $160 \mathrm{ppm}^{24}$.

Trembly et al. reported post-trial analyses using XRD, SEM, and EDS. These tests did not detect secondary chloride phases within the anode.

Richardson et al. ${ }^{63}$ investigated the deleterious effect that chlorine has on the water-gas shift reaction on nickel, which has implications for SOFCs. The results were obtained during an investigation of the destruction of chlorinated hydrocarbons by steam reforming. The reaction involving methyl chloride is as follows:

$$
\mathrm{CH}_{3} \mathrm{Cl}+\mathrm{H}_{2} \mathrm{O} \leftrightarrow \mathrm{CO}+\mathrm{H}_{2}+\mathrm{HCl}
$$

This reaction is similar to the methane-steam reforming (MSR) reaction, therefore it is predicted that this reaction would reach equilibrium as the MSR reaction does. However, this was not 
found to be the case and led the group to conclude that the presence of chloride species inhibits the WGS reaction while Equation 2.17 is unaffected. Therefore, the presence of chlorine (chlorinated hydrocarbons) may suppress the WGS reaction.

Krishnan et al ${ }^{64}$ concluded that the most likely poisoning effect of chlorine is due to some surface adsorption on the nickel catalyst, or some bulk effect on the supporting YSZ network. They also note that this is a postulation that requires verification.

\subsubsection{Group $\mathrm{V}^{*}$ Element - Phosphorus (P)}

Equilibrium calculations indicate that $\mathrm{P}$ may exist as $\left(\mathrm{P}_{2} \mathrm{O}_{3}\right)_{2}$ and $\mathrm{PH}_{3}$ depending on the temperature and pressure of the gas cleanup $\operatorname{system}^{16}$, but the speciation of phosphorus compounds in coal syngas has not been experimentally confirmed. Under SOFC operating conditions and atmospheric pressure, $\mathrm{PH}_{3}$ is hydrolyzed to form $\mathrm{HPO}_{2}$ vapor ${ }^{38}$.

Trembly et al. ${ }^{16}$ present thermodynamic arguments that $\mathrm{PH}_{3}$ in coal syngas forms $\mathrm{Ni}_{5} \mathrm{P}_{2}$ with exposure to nickel. The Gibbs free energy of the following reaction of $\mathrm{PH}_{3}$ and $\mathrm{Ni}$ is negative; therefore, $\mathrm{Ni}_{5} \mathrm{P}_{2}$ may be expected to form.

$$
2 \mathrm{PH}_{3}+5 \mathrm{Ni} \rightarrow \mathrm{Ni}_{5} \mathrm{P}_{2}(\mathrm{~s})+3 \mathrm{H}_{2}
$$

It was also reported that an increase in oxygen partial pressure may result in the formation of a secondary phosphorus trace species, $\left(\mathrm{P}_{2} \mathrm{O}_{3}\right)_{2}$ (g), which inhibits the formation of $\mathrm{PH}_{3}$, therefore reducing the amount of $\mathrm{Ni}_{5} \mathrm{P}_{2}$ formed in the nickel surface.

Phosphine may also react with water vapor present in the syngas to produce phosphoric acid as shown:

\footnotetext{
${ }^{*}$ Category of the periodic table of the elements.
} 


$$
\mathrm{PH}_{3}+4 \mathrm{H}_{2} \mathrm{O} \rightarrow \mathrm{H}_{3} \mathrm{PO}_{4}+4 \mathrm{H}_{2}
$$

The Gibbs free energy for this reaction is $-407.8 \mathrm{~kJ} / \mathrm{mol}$ and needs to be considered when accounting for the formation of phosphate phases as reported by Zhi et al. ${ }^{65}$

Trembly et al. ${ }^{42}$ tested the effect of phosphine $\left(\mathrm{PH}_{3}\right)$ on Ni/YSZ anode supported button cells exposed to simulated syngas $\left(\mathrm{H}_{2}-29 \% / \mathrm{CO}-29 \% / \mathrm{CO}_{2}-12 \% / \mathrm{N}_{2}-3 \% / \mathrm{H}_{2} \mathrm{O}-27 \%\right)$ containing $\mathrm{PH}_{3}$ at 2 and $5 \mathrm{ppm}$ under galvanostatic conditions of $0.25 \mathrm{~A} / \mathrm{cm}^{2}$ and at $750^{\circ} \mathrm{C}$. Marina et al. ${ }^{56}$ exposed anode supported button cells to a fuel $\left(\mathrm{H}_{2}-97 \% / \mathrm{H}_{2} \mathrm{O}-3 \%\right)$ and a simulated syngas fuel $\left(\mathrm{H}_{2}-30 \%\right.$ / $\left.\mathrm{CO}-23 \% / \mathrm{CO}_{2}-21 \% / \mathrm{H}_{2} \mathrm{O}-26 \%\right)$ containing $\mathrm{PH}_{3}$ at $2 \mathrm{ppm}$ under galvanostatic conditions of $0.5 \mathrm{~A} / \mathrm{cm}^{2}$ and temperatures of $700^{\circ} \mathrm{C}$ and $800^{\circ} \mathrm{C}$. Zhi et al. exposed a cell to a simulated syngas $\left(\mathrm{H}_{2}-31 \%\right.$ / $\left.\mathrm{CO}-30 \% / \mathrm{CO}_{2}-12 \% / \mathrm{H}_{2} \mathrm{O}-27 \%\right)$ doped with $20 \mathrm{ppm} \mathrm{PH}_{3}$ at $900^{\circ} \mathrm{C}$. Krishnan et al. ${ }^{38}$ reported results for exposure to an unknown bulk fuel containing $35 \mathrm{ppm} \mathrm{PH}_{3}$ at $750^{\circ} \mathrm{C}$ and $800^{\circ} \mathrm{C}$. Xu et al. ${ }^{66}$ exposed a cell to a simulated syngas $\left(\mathrm{H}_{2}-30 \% / \mathrm{CO}-23 \% / \mathrm{CO}_{2}-21 \% / \mathrm{H}_{2} \mathrm{O}-26 \%\right)$ doped with $10 \mathrm{ppm} \mathrm{PH}_{3}$ at a temperature of $800^{\circ} \mathrm{C}$. Pederson et al. ${ }^{49}$ also reported results for $\mathrm{PH}_{3}$ exposure, although few details are disclosed.

Marina et al. did not note an immediate degradation in the cell output upon initial introduction of the trace material. Krishnan et al. noted that at $750^{\circ} \mathrm{C}$, degradation occurred primarily within the first 20 hours of operation, with a loss of about $10 \mathrm{~mW} / \mathrm{cm}^{2}$, but that the degradation rate slowed over the remaining 100 hours of testing with less than $0.03 \mathrm{~mW} / \mathrm{cm}^{2}$ per h. ${ }^{64}$ Experiments conducted at $800^{\circ} \mathrm{C}$ show an accelerated rate at $0.18 \mathrm{~mW} / \mathrm{cm}^{2}$ per h of degradation. Figure 2.6 shows the cell characterization from SEM and EDX methods after exposure to $35 \mathrm{ppm} \mathrm{PH}_{3}$. In Figure 2.6a, the surface is "etched" by the contaminant, and small, 
irregular particles are exposed. These are surrounded by some large patches that are still intact. Figure 2.6b shows the elemental mapping of the corresponding anode surface area by EDX analysis. The large patches comprise mostly nickel and are surrounded by $\mathrm{P} / \mathrm{Zr}$. This shows that P most likely segregated to the boundaries of the catalyst.

(a)

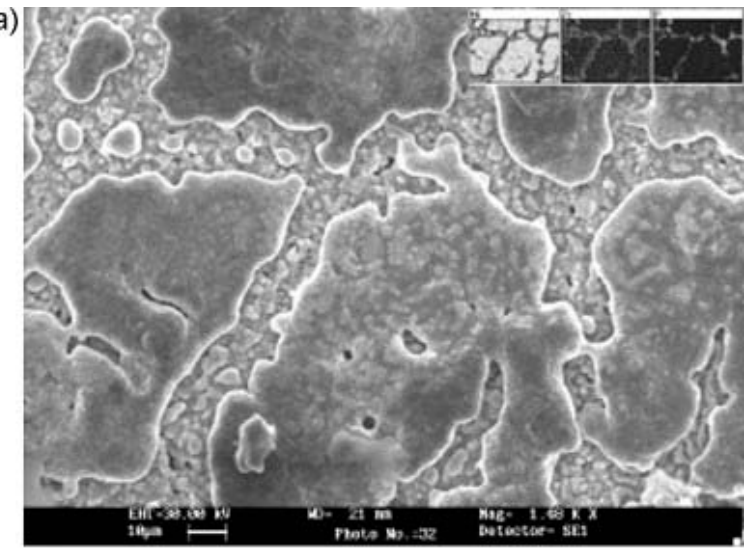

(b)

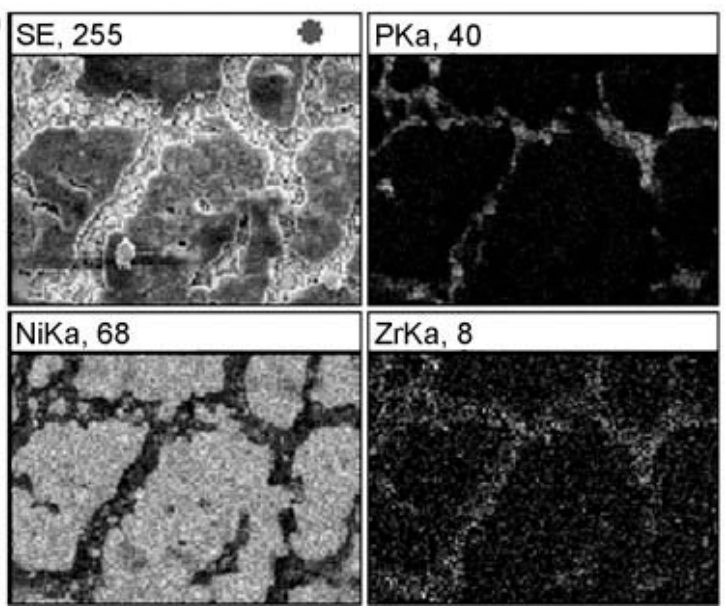

Figure 2.6 - Surface morphology of the cell after exposure to 35 ppm $\mathrm{PH}_{3}$. a) SEM photo micrograph b) Xray elemental map

Marina et al. reported the data contained in Figure 2.7, which depicts irreversible cell degradation during the $600 \mathrm{~h}$ tests for $2 \mathrm{ppm} \mathrm{PH}_{3}$ exposure. The area specific resistance of the system increased at a rate of $130-200 \% / 1000 \mathrm{~h}$, and the cells continued to degrade even after removal of the phosphorus from the system. All nickel surfaces in the system (contact paste,

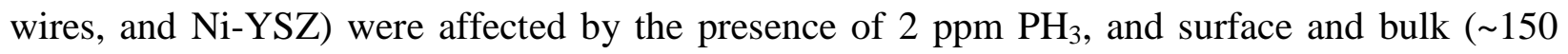


$\mu \mathrm{m}) \mathrm{Ni}_{3} \mathrm{P}$ was formed during a $700 \mathrm{~h}$ test at $800^{\circ} \mathrm{C}$. The $\mathrm{Ni}_{3} \mathrm{P}$ showed extensive agglomeration and self-crystallization followed by the densification of the upper nickel layer. The similar grain orientation of other $\mathrm{Ni}_{3} \mathrm{P}$ grains suggests partial melting and solidification as a single grain. In addition, a nickel deficient layer was found in the upper part of the Ni-YSZ affecting the nickel percolation.

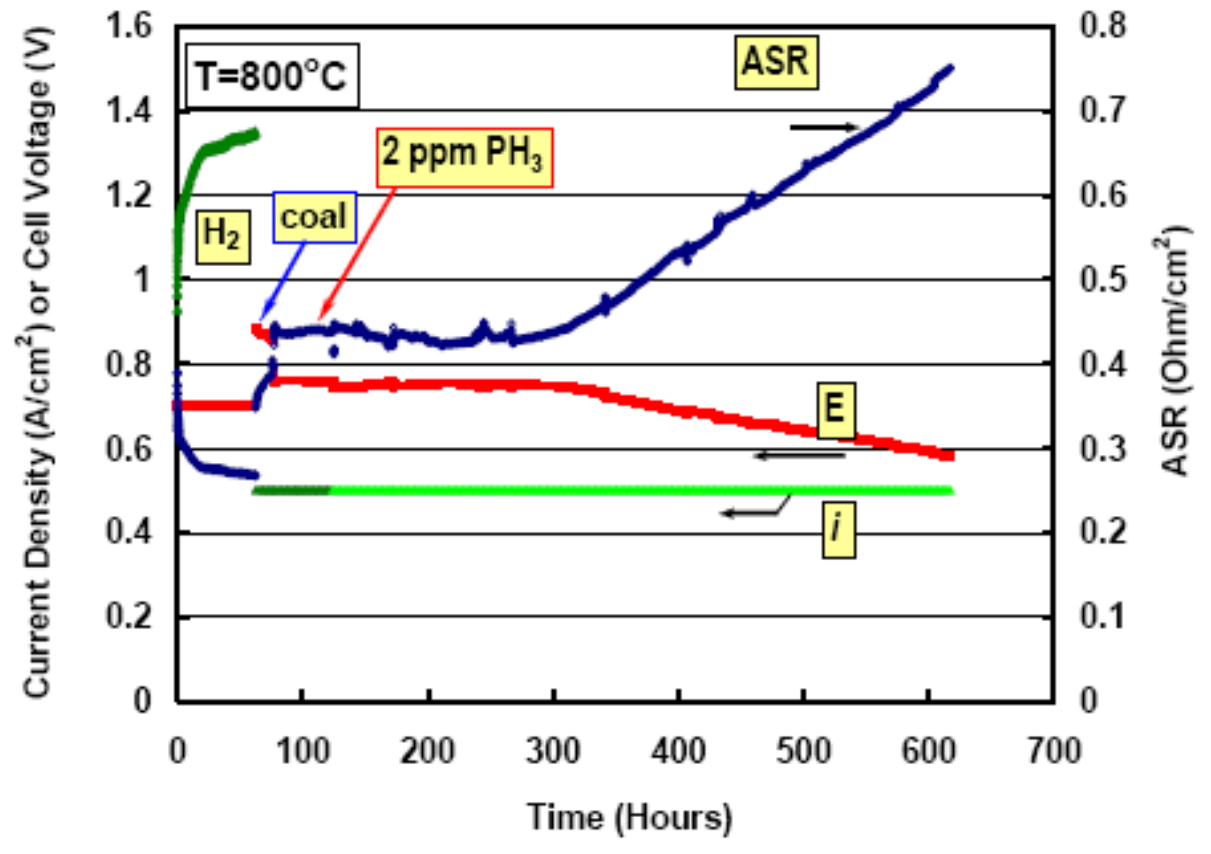

Figure 2.7 - SOFC performance of cell operating at $800^{\circ} \mathrm{C}$ exposed to $2 \mathrm{ppm}^{\mathrm{PH}_{3} \text { in coal syngas }}{ }^{48}$.

Zhi et al. reported the formation of the phosphates $\mathrm{Ni}_{3}\left(\mathrm{PO}_{4}\right)_{2}$ and $\mathrm{ZrP}_{2} \mathrm{O}_{7}$ using XRD analysis when cells were operated at open-circuit. In cells operated under load, the zirconia phosphate was not present.

$\mathrm{Xu}$ et al. reported a cell potential degradation of $0.46 \mathrm{mV} / \mathrm{h}$ when exposed to $10 \mathrm{ppm} \mathrm{PH}_{3}$. XPS shows traces of a $\mathrm{P}_{2} \mathrm{O}_{5}$ or $\mathrm{PO}_{4}{ }^{3-}$ phase on the cell surface and $\mathrm{Ni}_{5} \mathrm{P}_{2}$ in the bulk. The group 
also noted that nickel had migrated to the surface. XPS shows no YSZ peak on the surface, indicating that the nickel and nickel compounds have completely covered the surface of the cell.

The poisoning effect of phosphorus as studied by Krishnan et al. ${ }^{38}$ revealed that for $100 \mathrm{~h}$ of testing, $10 \mathrm{ppm} \mathrm{HPO}_{2}$ at 750 and $800^{\circ} \mathrm{C}$ degrades the anode.

Data reported by Trembly et al. ${ }^{42}$ did not show any significant impact at either concentration on the performance of the SOFC during a test lasting $150 \mathrm{~h}$. For the $2 \mathrm{ppm}$ test, the starting average potential was $0.686 \pm 0.002 \mathrm{~V}$ with the potential after $\mathrm{PH}_{3}$ injection being $0.685 \pm 0.004 \mathrm{~V}$. The cell operating on $5 \mathrm{ppm} \mathrm{PH}_{3}$ had a starting average potential of $0.676 \pm 0.002 \mathrm{~V}$ with the potential after $\mathrm{PH}_{3}$ injection being $0.688 \pm 0.004 \mathrm{~V}$, showing an increase in average potential leading the group to conclude that no degradation is occurring.

Trembly et al. performed a post trial investigation by XRD, which showed that a secondary nickel phosphide $\left(\mathrm{Ni}_{3} \mathrm{P}\right)$ formed at both the 2 and $5 \mathrm{ppm} \mathrm{PH}_{3}$ exposures. These phases may affect the performance over periods of exposure longer than those tested in these experiments may. Pederson et al. ${ }^{49}$ found the same formation as did Trembly et al., however they determined that there is an additional nickel phosphide secondary phase, namely $\mathrm{Ni}_{2} \mathrm{P}$. In a test conducted at

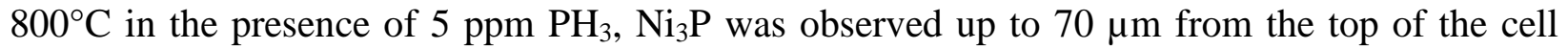
using XPS and transmission electron microscopy (TEM). The phosphine did not react with either zirconia or ceria based anodes in this case.

\subsubsection{Group V ${ }^{*}$ Element - Arsenic (As)}

Arsenic can be found in most United States coal deposits in concentrations ranging from 0.52090 ppm by mass ${ }^{50}$. Arsenic is volatilized during gasification and is predicted to partially circumvent warm gas cleanup systems ${ }^{16}$. Post-warm gas cleanup species include $\mathrm{As}_{4}, \mathrm{AsH}_{3}$, and

\footnotetext{
${ }^{*}$ Category of the periodic table of the elements
} 
$\mathrm{As}_{3} \mathrm{~Pb}$, with $\mathrm{As}_{4}$ being the most abundant ${ }^{16}$. Prior research and thermodynamic calculations have indicated that arsenic levels in the range $0.15-0.60 \mathrm{ppm}$ of arsenic are needed to form nickel arsenide phases in water-gas shift catalysts ${ }^{50-52}$.

Trembly et al. ${ }^{41}$ used thermodynamic calculations to predict the formation of nickel arsenide (NiAs) based on the reaction:

$$
\mathrm{AsH}_{3}+\mathrm{Ni} \rightarrow \mathrm{NiAs}+1.5 \mathrm{H}_{2}
$$

The nickel-arsenide enthalpy change is favorable to formation. As shown in Figure 2.8, the equilibrium partial pressure associated with $\mathrm{AsH}_{3}$ for the formation of NiAs is much lower than the concentration found in actual coal syngas compositions. Given sufficiently fast kinetics, formation of $\mathrm{Ni}_{\mathrm{x}} \mathrm{As}_{\mathrm{y}}$ phases are expected. 


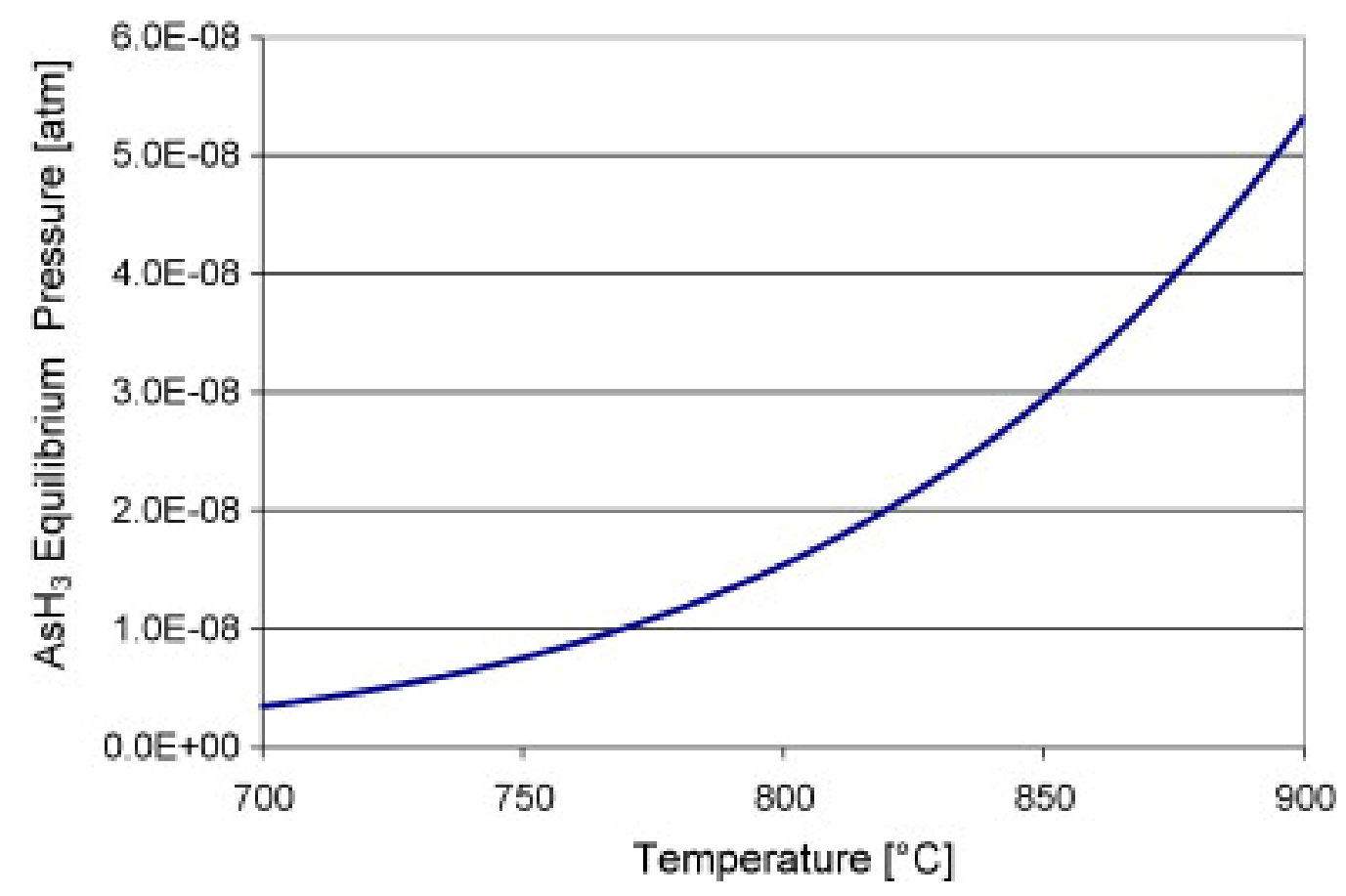

Figure 2.8 $-\mathrm{AsH}_{3}$ equilibrium partial pressures for Equation 2.19 over SOFC operational temperature range and $0.29 \mathrm{~atm} \mathrm{H}_{2}{ }^{41}$.

Ng et al. ${ }^{52}$ studied arsine adsorption at room temperature on a nickel catalyst and found that the observed catalyst deactivation was greater than expected from a simple surface coverage model. Arsenic was postulated to penetrate the surface. In a separate work, Ng et al. ${ }^{51}$ showed that arsenic adsorption changed the nature of ethene adsorption on nickel. The dissociation of ethene at low coverage and its self-hydrogenation at high coverage were suppressed. The surface adsorbed arsenic blocked the surface sites for desorption, but also migrated from the surface into the bulk nickel phase. Heating of the sample improved the adsorption of ethene, probably by increasing the mobility of the arsine in the bulk nickel and imparting sufficient energy for production of a bulk $\mathrm{Ni}$-As phase.

Trembly et al. ${ }^{41}$ tested the effect of arsine on Ni/YSZ anode-supported button cells exposed to a simulated syngas $\left(\mathrm{H}_{2}-29 \% / \mathrm{CO}-29 \% / \mathrm{CO}_{2}-12 \% / \mathrm{N}_{2}-3 \% / \mathrm{H}_{2} \mathrm{O}-27 \%\right)$ containing arsine $\left(\mathrm{AsH}_{3}\right)$ at $0.1,1$, and $2 \mathrm{ppm}$ under galvanostatic conditions of 0.25 and $0.50 \mathrm{~A} / \mathrm{cm}^{2}$ and at 
$750^{\circ} \mathrm{C}$ and $800^{\circ} \mathrm{C}$. Marina et al. ${ }^{48}$ exposed anode supported button cells to a fuel $\left(\mathrm{H}_{2}-97 \%\right.$ / $\left.\mathrm{H}_{2} \mathrm{O}-3 \%\right)$ and a simulated syngas fuel $\left(\mathrm{H}_{2}-30 \% / \mathrm{CO}-23 \% / \mathrm{CO}_{2}-21 \% / \mathrm{H}_{2} \mathrm{O}-26 \%\right)$ containing $\mathrm{AsH}_{3}$ at $1 \mathrm{ppm}$ under galvanostatic conditions of $0.5 \mathrm{~A} / \mathrm{cm}^{2}$ and a temperature of $800^{\circ} \mathrm{C}$. Krishnan et al. ${ }^{38}$ reported results for exposure to an unknown bulk fuel containing 10 ppm $\mathrm{As}_{2}$ at $750^{\circ} \mathrm{C}$ and $800^{\circ} \mathrm{C}$. Pederson et al. ${ }^{49}$ also reported results for $\mathrm{AsH}_{3}$ exposure, although few details are disclosed.

The experiments performed by Trembly et al. ${ }^{41}$ and Marina et al ${ }^{67}$ showed no immediate depression in cell output potential upon introduction of $0.1 \mathrm{ppm}$ and $1 \mathrm{ppm} \mathrm{AsH}_{3}$. At $2 \mathrm{ppm}$ $\mathrm{AsH}_{3}$, Trembly et al. observed a slight initial depression in cell output at $750^{\circ} \mathrm{C}$. Steady degradation rates of $\sim 10 \%$ per $1000 \mathrm{~h}$ were observed by Marina et al. for both coal syngas and hydrogen bulk gas, while degradation rates of $100-200 \%$ per $1000 \mathrm{~h}$ were observed by Trembly et al. ${ }^{41}$ and Pederson et al. ${ }^{49}$. Krishnan et al. ${ }^{38}$ observed initial degradation over 10 hours followed by steady performance for 60 hours at $750^{\circ} \mathrm{C}$ and erratic performance (attributed to connection failure) at $800^{\circ} \mathrm{C}$. Figure 2.9 shows an extended time trial completed by Trembly et al. ${ }^{41}$ involving $0.1 \mathrm{ppm}$ of $\mathrm{AsH}_{3}$ in simulated syngas at $800^{\circ} \mathrm{C}$. Degradation rates were steady for the duration of the test, and did not appear to be reversible in any case.

Marina et al. ${ }^{48}$ obtained EBSD data showing formation of $\mathrm{Ni}_{5} \mathrm{As}_{2}$ at the free gas stream anode surface after 70 hours of operation. Additional data showed that As had penetrated the free gas surface by $45 \mu \mathrm{m}$ after 700 hours of exposure. Trembly et al. ${ }^{41}$ examined the cell by XRD and SEM/EDS. Cells exposed for 100 hours did not contain detectable $\mathrm{Ni}_{\mathrm{x}} \mathrm{As}_{\mathrm{y}}$ phases, even for exposure concentrations of 1 and $2 \mathrm{ppm}$. The cell exposed to $0.1 \mathrm{ppm}$ for 800 hours did exhibit detectable arsenic near the free gas surface. 


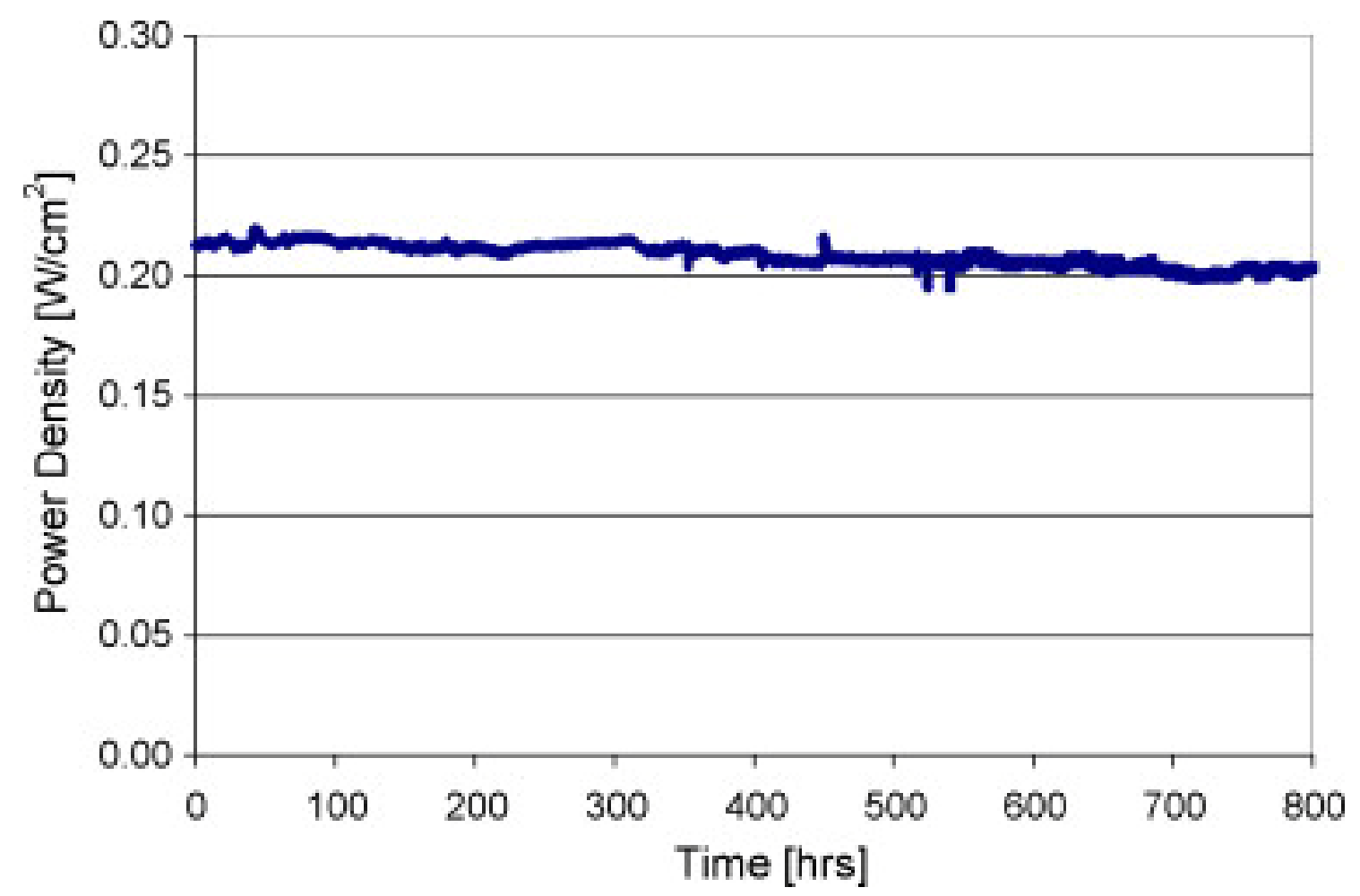

Figure 2.9 - SOFC performance at $800^{\circ} \mathrm{C}$ and $0.25 \mathrm{~A} / \mathrm{cm}^{2}$ with fuel containing $0.1 \mathrm{ppm} \mathrm{AsH}_{3}$ (the time prior to $\mathrm{AsH}_{3}$ injection is not shown $)^{41}$.

Arsenic is expected to have a strong affinity for the nickel surfaces and will be strongly attracted even at high temperatures. Preferential deposition of the arsenic at the free gas anode surface and extreme degradation of current collectors and connecting wires appear to confirm the strong attraction. The rate of secondary phase formation remains in disagreement with data sets indicating substantial $\mathrm{Ni}_{\mathrm{x}} \mathrm{As}_{\mathrm{y}}$ phase formation after 70 hours ${ }^{48}$ and only after 800 hours ${ }^{41}$. Further observations must be made before a realistic mechanism can be postulated.

\subsubsection{Group $\mathrm{V}^{*}$ Element - Antimony (Sb)}

Trembly et al. report that antimony is present in coal syngas in the form $\mathrm{SbO}_{2} \mathrm{H}_{2}$ after warm gas cleanup ${ }^{16} . \mathrm{As}_{3} \mathrm{Sb}$ is also present at temperatures of $500^{\circ} \mathrm{C}$ and is found to have a concentration of 0.01 ppmv after warm-gas cleanup ${ }^{16}$. Based upon thermodynamic calculations

\footnotetext{
${ }^{*}$ Category of the periodic table of the elements.
} 
they showed that $\mathrm{As}_{3} \mathrm{Sb}$ has the potential to interact with the SOFC anode to form NiSb(s). The interaction potential is greatest at low temperatures $\left(\sim 700^{\circ} \mathrm{C}\right)$ and low pressures $(\sim 1 \mathrm{~atm})$. The reaction is postulated to occur as shown:

$$
A s_{3} \mathrm{Sb}+\mathrm{Ni} \rightarrow \mathrm{NiSb}+0.75 \mathrm{As}_{4}
$$

A single published report contains results for the interaction of antimony with the nickel anode. Krishnan et al. ${ }^{38}$ studied the effect of antimony in the form SbO which was claimed to be the stable gaseous specie under anode operating conditions. The inclusion of $8 \mathrm{ppm}$ SbO in the fuel stream did not result in any decline in the cell performance at 750,800 , or $850^{\circ} \mathrm{C}$ after 100 hours of operation under galvanostatic conditions of $0.3 \mathrm{~A} / \mathrm{cm}^{2}$. At $750^{\circ} \mathrm{C}$, no degradation is reported, while at 800 and $850^{\circ} \mathrm{C}$ degradation was reported to be $0.03 \mathrm{~mW} / \mathrm{cm}^{2}$ per h and 0.04 $\mathrm{mW} / \mathrm{cm}^{2}$ per h, respectively. ${ }^{64}$ Krishnan et al. recommend that additional long-term tests be performed before concluding that Sb is a benign element.

\subsubsection{Ammonia $\left(\mathrm{NH}_{3}\right)$}

Wojcik et al. ${ }^{68}$ have used ammonia as a fuel source in SOFCs. The study showed that ammonia can be used directly as a fuel in a SOFC system. The power performance is similar to that of pure hydrogen. When a platinum anode is used, the power densities increased considerably. The group concluded that ammonia could work well with nickel anodes and nickel or iron-based catalysts in a SOFC system.

A study conducted by Westinghouse Electric Corporation (Pittsburgh, PA) in 1993, sought to determine the long-term performance of SOFCs with a coal syngas mixture containing ammonia 
$\left(\mathrm{NH}_{3}\right)$, hydrogen sulfide $\left(\mathrm{H}_{2} \mathrm{~S}\right)$, and hydrochloric acid $(\mathrm{HCl})^{53}$. The group concluded that ammonia impurities of up to $5000 \mathrm{ppm}$ in a simulated coal syngas did not present a measurable SOFC potential degradation over approximately 6500 hours of testing. There were no expected effects from ammonia with an extended testing period.

Dekker and Rietveld ${ }^{69}$ have also tested ammonia as a fuel source in a SOFC. The group used both electrolyte-supported and anode-supported planar cells (Innovative Dutch Electro Ceramics). The group was able to prove that ammonia can be used on these types of cells, generating $0.35 \mathrm{~A} / \mathrm{cm}^{2}$ with $70 \%$ efficiency and $0.60 \mathrm{~A} / \mathrm{cm}^{2}$ with $60 \%$ efficiency. The degradation of the cells during a 3000-hour test was less than $1 \%$ per $1000 \mathrm{~h}$. This process generates $\mathrm{NO}_{\mathrm{x}}$ compounds at high temperatures, producing $0.5 \mathrm{ppm}$ at $950^{\circ} \mathrm{C}$ and $4 \mathrm{ppm}$ at $1000^{\circ} \mathrm{C}$.

Ammonia is not expected to affect cell performance permanently. Site blockage by preferential adsorption/reaction may occur, but this is not a severe performance issue since $\mathrm{H}_{2}$ will readily participate in the electrochemistry. Secondary phase formation is of no concern.

\subsection{8. $\underline{\text { Cadmium }(\mathrm{Cd})}$}

At temperatures $300^{\circ} \mathrm{C}$ and higher, cadmium is partitioned between vapor (73\%) and solid (27\%) phases. At temperatures above $400^{\circ} \mathrm{C}$, elemental cadmium vapor is solely present in the syngas stream. At elevated temperatures and in the presence of chlorine, cadmium can form $\mathrm{CdCl}_{2}$ vapors ${ }^{16}$.

Krishnan et al. ${ }^{38,64}$ exposed a fuel cell to an unknown bulk gas doped with cadmium vapor. At an operating temperature of $800^{\circ} \mathrm{C}$ and galvanostatic conditions of $0.222 \mathrm{~A} / \mathrm{cm}^{2}$, the $5 \mathrm{ppm}$ cadmium vapor exposure did not produce adverse performance effects during a 150 hour test period. At an operating temperature of $850^{\circ} \mathrm{C}$ and all other conditions the same, the cell showed 
no initial degradation, but a steadily increasing degradation over the final 70 hours of a 120 hour test. Post-test analysis did not show any detectible level of $\mathrm{Cd}$ on the cell surface. This is expected because of the volatility of $\mathrm{Cd}$ vapor and the probable evaporation during the cool down procedure.

\subsubsection{Silicon (Si) and Lead $(\mathrm{Pb})$}

Silicon arising from impurities in raw materials used for cell component fabrication has been shown to have a deleterious effect on anode polarization ${ }^{54}$. Ray et al. ${ }^{53}$ reported on the possibility of silica $\left(\mathrm{SiO}_{2}\right)$ poisoning on a nickel surface. In the reverse of Reaction 2.21, forming $\mathrm{SiO}_{2}$ is favored as the MSR reaction consumes water:

$$
\mathrm{SiO}_{2}+2 \mathrm{H}_{2} \mathrm{O} \leftrightarrow \mathrm{Si}(\mathrm{OH})_{4}
$$

Coverage of nickel by silica would impede transport of hydrogen fuel and decrease output potential. It should be noted that pore blockage has not been observed.

Lead is in the same group as silicon on the periodic table, and may travel to the SOFC when using high temperature gas cleanup systems. At gas cleanup temperatures of $400^{\circ} \mathrm{C}$, no gas phase lead species is predicted to emerge from cleanup trains operating at pressures up to $15 \mathrm{~atm}$. At gas cleanup temperatures of $500^{\circ} \mathrm{C}$, lead vapor and $\mathrm{PbSe}$ gases are formed but no tendency to form oxides is predicted ${ }^{16}$. There has been no published report of the interaction of lead with the nickel anode.

\subsubsection{Mercury (Hg)}

Mercury is expected to be in vapor form in the coal syngas due to its high vapor pressure ${ }^{16}$. Mercury adsorption onto a number of metal surface (including nickel) was probed using density functional theory calculations by Steckel ${ }^{70}$. Attraction to nickel (001) and (111) surfaces was 
predicted for several adsorption configurations, although the assumptions of temperature and pressure for the calculation are not relevant to fuel cell operation.

Krishnan et al. ${ }^{38}$ reported the only published results for Hg exposure tests. When the cell is exposed to $0.18 \mathrm{ppm}$ and $7 \mathrm{ppm}$ of mercury, the performance of the cell shows no significant degradation after 150 hours of testing. It was thought that $\mathrm{HgO}$ condensed and deposited on the surface of the anode, ${ }^{16}$ hindering the diffusion of the hydrogen and contacting with the YSZ electrolyte to alter the oxidation of the fuel species. However, thermodynamic predictions indicate that Hg shows no tendency to form oxides ${ }^{16}$. Krishnan et al. suggest additional long term testing for this element.

\subsubsection{Zinc (Zn)}

Although zinc derived from the gasification process itself is not expected to pass through the particulate collection device systems ${ }^{16}$, zinc is present in the sorbent material used to remove $\mathrm{H}_{2} \mathrm{~S}$ from a coal gas stream, and therefore may be present as fine particles or vapor in the cleaned coal syngas stream. At elevated temperatures $\left(400-800{ }^{\circ} \mathrm{C}\right)$ and in the presence of chlorine, zinc can form $\mathrm{ZnCl}_{2}$ vapors ${ }^{38}$.

Experiments have been conducted for zinc exposure by two groups. Ray et al. ${ }^{53}$ exposed two $50 \mathrm{~cm}$ length SOFCs to an unknown concentration of zinc under galvanostatic conditions of 350 $\mathrm{mA} / \mathrm{cm}^{2}$ at $1000^{\circ} \mathrm{C}$. Krishnan et al. ${ }^{38}$ exposed cells to simulated syngas of unknown composition containing $10 \mathrm{ppm}$ zinc under galvanostatic conditions of $0.2 \mathrm{~A} / \mathrm{cm}^{2}$ at $750^{\circ} \mathrm{C}$ and $800^{\circ} \mathrm{C}$.

Ray et al. reported that after an initial potential loss, the cells behaved normally for 2800 hours. The group also continued testing on one of the cells for an additional 1400 hours. They then added $\mathrm{HCl}$ to the fuel. Over the entire test duration, cell performance appeared to be unaffected. Krishnan et al. reported that the zinc produced no effect on cell output at $750^{\circ} \mathrm{C}$ and 
only modest degradation at $800^{\circ} \mathrm{C}$ for the 120 -hour tests. Ray et al. conducted electron beam microanalyses on both samples, with no zinc being detected. No microanalysis was conducted by Krishnan et al.

\subsubsection{Carbon (C) Deposition on Nickel Surfaces}

When the gasification process is operated at lower temperatures or when biomass is the fuel source, it is expected that a larger amount of HHCs is going to be present. Carbon deposition on nickel catalysts from tar and other hydrocarbons was been well documented in the literature. However, there is little experimental data available to relate carbon deposition directly with SOFC.

The amount and type of tars present in the syngas depend on gasification conditions ${ }^{71}$. In a study conducted by Singh et al. ${ }^{72}$, benzene was used as the primary component when simulating gasification tars. Therefore, benzene is considered a representative molecule of aromatics and tar in regards its effects on SOFC performance. Formation of carbon can take place either by methane cracking (Equation 2.22) or the Boudouard reaction (Equation 2.23):

$$
\begin{aligned}
& \mathrm{CH}_{4} \Rightarrow \mathrm{C}+2 \mathrm{H}_{2} \\
& 2 \mathrm{CO} \Leftrightarrow \mathrm{C}+\mathrm{CO}_{2}
\end{aligned}
$$

As nickel is an active catalyst for hydrocarbon cracking reactions, it is postulated that the trace hydrocarbons in the fuel will be cracked, depositing nucleating carbon on anode surfaces and ultimately blocking reaction sites. Sehested $^{73}$ adds that carbon formation would also increase pressure drop and form at the inner perimeter of reforming tubes, resulting in a lower heat transfer. Elemental surface carbon has been shown to preferentially adsorb onto five adjacent nickel atoms, stabilizing to form more ordered graphitic deposits ${ }^{74}$. 
Tars that would ordinarily condense are found in the gas phase due to the high temperatures involved in gasification. Milne and Evans ${ }^{75}$ describe a typical biomass tar composition, which is reproduced in Table 2.4. Singh et al. ${ }^{72}$ conducted a thermodynamic analysis of carbon deposition in a SOFC fueled by a biomass gasifier. They suggested using a hydrocarbon mixture with representative species including benzene (representing one-ring aromatics) and naphthalene (representing two-ring aromatics) being the majority (65 and 20 percent, respectively) of the composition. The amount of carbon deposited is sensitive to the steam/carbon ratio, temperature, anode material, and cell operating current density. Deposition decreases with increases in steam/carbon ratio or with increases in current density. Singh et al. reported a maximum deposition at OCV using syngas fuel doped with $2 \%$ of a tar mixture, as shown in Figure 2.10.

Table 2.4 - Typical composition of biomass gasification $\operatorname{tars}^{75}$

\begin{tabular}{|l|c|}
\hline \multicolumn{1}{|c|}{ Compound } & $\begin{array}{c}\text { Composition } \\
\text { (Weight \%) }\end{array}$ \\
\hline Benzene & 37.9 \\
\hline Toluene & 14.3 \\
\hline Other one-ring aromatics & 13.9 \\
\hline Naphthalene & 9.6 \\
\hline Other two-ring aromatics & 7.8 \\
\hline Three-ring aromatics & 3.6 \\
\hline Four-ring aromatics & 0.8 \\
\hline Phenolic compounds & 4.6 \\
\hline Heterocyclic compounds & 6.5 \\
\hline Others & 1.0 \\
\hline
\end{tabular}




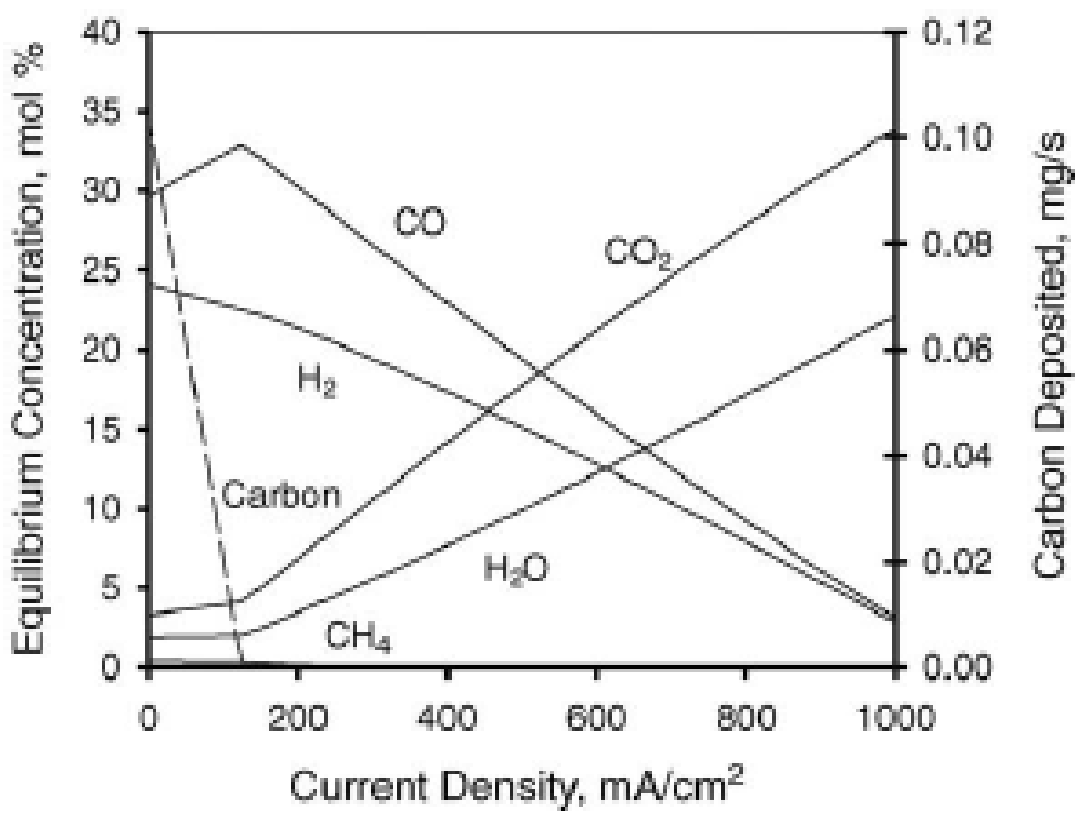

Figure 2.10 - Equilibrium diagram of main species as a function of current density for a mixture comprising $20 \% \mathrm{CO}, 15 \% \mathrm{H}_{2}, 10 \% \mathrm{CO}_{2}, 5 \% \mathrm{H}_{2} \mathrm{O}, 2 \% \mathrm{CH}_{4}, 48 \% \mathrm{~N}_{2}$, and tar as $2 \%$ of the total mixture at $750^{\circ} \mathrm{C}$.

Coll et al. $^{76}$ studied benzene, toluene, naphthalene, anthracene, and pyrene for their propensity to deposit carbon during steam reforming. The relative reactivity was found to be benzene $>$ toluene $>>$ anthracene $>>$ pyrene $>$ naphthalene, showing that naphthalene is the hardest tar to decompose due to its stability. As benzene was shown to be the most reactive tar component, it would be a sensitive indicator of the impact of tars on cell performance.

Koh et al. ${ }^{77}$ reported data from a SOFC exposed to a dry methane fuel stream. The cell potential drops steadily over a 500-hour test period. Examination revealed no visual carbon on the anode surface; however, carbon had deposited mostly on the outlet gas tubing and at the anode fuel feed tube entrance. The degradation was attributed to the partial clogging of the fuel feed tubing. Cells were operated at a current density of $0.2 \mathrm{~A} / \mathrm{cm}^{2}$.

He at al. ${ }^{78}$ exposed Ni-YSZ pellets to humidified methane for 4 hours. Significant carbon formations developed including carbon nanotubes at temperatures up to $700^{\circ} \mathrm{C}$. At $800^{\circ} \mathrm{C}$, all of 
the carbon appeared to have dissolved into the nickel particles. SEM results showed that YSZ was able to maintain its shape, while the nickel particles became sponge-like. There was no current applied to the pellets.

Staniforth et al. ${ }^{79}$ used biogas (from the anaerobic bacteria digestion of organic matter) to fuel a small tubular SOFC. In order to mitigate carbon deposition on the anode surface, air was added to the fuel stream to oxidize elemental carbon. The composition of the fuel was $\left(\mathrm{CH}_{4}-\right.$ $27.3 \% / \mathrm{CO}_{2}-13.6 \%$ / $\left.\mathrm{Air}-68.1 \%\right)$.

A study by Baird et al. ${ }^{80}$ postulated a mechanism by which the carbon uptake rate on a nickel catalyst decayed over time. The group found that the carbon deposition rate decreased from about $1 \mathrm{mg} / \mathrm{h}$ to $0.1 \mathrm{mg} / \mathrm{h}$ over a $36 \mathrm{~h}$ period. Baird et al. reported that their findings were consistent with similar experiments conducted on the decomposition of CO and hydrocarbons on nickel surfaces.

It is known that the kinetics of carbon deposition are affected by gas composition. Chun et al. ${ }^{81}$ found that if the $\mathrm{CO} / \mathrm{H}_{2}$ ratio is $25: 1$, pure nickel formed a surface layer of graphite and dusted (became particles of carbon and nanoparticulate metal). However, if the ratio is 1:1, internal grain boundary precipitation of graphite resulted. Grabke et al. ${ }^{82,83}$ contended that Equation 2.24 is the dominant carbon forming reaction from $\mathrm{CO} / \mathrm{H}_{2} / \mathrm{H}_{2} \mathrm{O}$ mixtures at elevated temperatures with 2.25 and 2.26 not playing a large role.

$$
\begin{gathered}
\mathrm{CO}+\mathrm{H}_{2} \Leftrightarrow \mathrm{C}+\mathrm{H}_{2} \mathrm{O} \\
\mathrm{CH}_{4} \Rightarrow \mathrm{C}+2 \mathrm{H}_{2} \\
2 \mathrm{CO} \Leftrightarrow \mathrm{C}+\mathrm{CO}_{2}
\end{gathered}
$$

If this is indeed the case, then the supersaturated carbon activity can be calculated as: 


$$
a_{C}=\frac{K_{1} p_{C O} p_{H_{2}}}{p_{H_{2} O}}
$$

where $K_{1}=\exp \left(-\Delta G^{0}{ }_{1} / R T\right)$, and $\Delta G^{0}{ }_{1}=-134,515+142.37 T(\mathrm{~J})^{84}$. The group kept $a_{\mathrm{C}}$ fixed in their experiments, varying $p_{\mathrm{CO}}$. Grabke et al. postulated a carbon uptake rate of:

$$
r=k p_{C O} p_{H_{2}}
$$

Zhang et al. ${ }^{85}$ reported a linear weight gain trend over time that increased in slope as the concentration of $\mathrm{CO}$ increased from 0.31 to 0.50 atm, increased more slowly from 0.50 to 0.68 atm and decreased above 0.68 atm. After $100 \mathrm{~h}$ of testing, a carbon layer was formed with a small amount of nickel in the layer. The fuel used was $\mathrm{CO}$ with balance $\mathrm{H}_{2}$.

The results from Zhang et al. do not match up with Equation 2.28, requiring additional terms to be added to the rate equation. The group contends that Equation 2.24 does play a role at large $p_{C O}$, and Equation 2.25 plays a role at large $p_{H 2}$. The group proposes the rate equation:

$$
r=r_{1}+r_{2}-r_{3}=k_{1} p_{C O} p_{H_{2}}+k_{2} p_{C O}^{2}-k_{3} p_{H_{2}}^{2}
$$

with $k_{1}=0.73 \mathrm{mg} /\left(\mathrm{cm}^{2} \times \mathrm{atm}^{2} \times \mathrm{h}\right), k_{2}=0.06 \mathrm{mg} /\left(\mathrm{cm}^{2} \times \mathrm{atm}^{2} \times \mathrm{h}\right), k_{3}=0.27 \mathrm{mg} /\left(\mathrm{cm}^{2} \times \mathrm{atm}^{2} \times \mathrm{h}\right)$. 


\section{CHAPTER THREE - EXPERIMENTAL WORK}

\subsection{Experimental Setup}

Solid oxide fuel cell button cells are employed in all of the following experiments as described in this section. The anode-supported button cells were fabricated by MSRI (Salt Lake City, UT). The cells featured a $0.8 \mathrm{~mm}$ Ni-8YSZ anode, a 10 or $20 \mu \mathrm{m}$ YSZ electrolyte, and a $20 \mu \mathrm{m}$ LSM cathode. The cells also contained a $25 \mu \mathrm{m}$ thick Ni-YSZ anode interlayer featuring a tailored Ni grain size and a $25 \mu$ m thick cathode interlayer which was a composite LSM/YSZ. Current-collecting meshes are attached to each electrode (nickel - anode, platinum - cathode) using nickel paste and platinum paint, respectively. Silver current cables and potential taps are spot welded onto opposite sides of each current-collecting mesh. The cells are mounted between two alumina flanges with mica ceramic o-rings for sealing. Figure 3.1 shows a schematic and Figure 3.2 shows a photograph of the mounting apparatus, while a photograph of the entire fuel cell test apparatus is shown in Figure 3.3. Figure 3.4 is a schematic diagram of the flow pathways.

For each experiment, the button cell assembly is mounted in a split tube furnace operated at $800^{\circ} \mathrm{C}$. Alicat ${ }^{\mathrm{TM}}$ mass flow controllers (MFCs) are used to control the fuel and air stream flow rates and compositions. Separate MFCs are used to control the flow rates of $\mathrm{H}_{2}, \mathrm{CO}, \mathrm{CO}_{2}$, and $\mathrm{N}_{2}$ to the anode and air to the cathode. The zero and span shift for these controllers are $0.02 \%$. A temperature-controlled humidifier was used to control the water content of the simulated coal syngas provided to the anode. A Compact FieldPoint system from National Instruments is used to collect voltage, current, and temperature data. The gain error drift for the potential and current 
collection device is $\pm 2 \times 10^{-5} /{ }^{\circ} \mathrm{C}$. The offset error drift is $6 \mu \mathrm{V} /{ }^{\circ} \mathrm{C}$. The gain error for the thermocouple-reading device is $0.01-0.03 \%$.

The total fuel flow rate was kept at approximately $300 \mathrm{sccm}$ and the airflow rate was kept at approximately $1000 \mathrm{sccm}$. The anode flow lines were heat traced well above $100^{\circ} \mathrm{C}$ to ensure no condensation would take place between the humidifier and split tube furnace. Trace species are added to a stream by a permeation tube or diffusion vial device supplied by VICI Metronics. The flow rates of these devices are maintained by a controlled temperature oven (Dynacalibrator 150) that controls to a value of $\pm 0.01^{\circ} \mathrm{C}$. The required temperature depends on the desired trace species and its concentration.

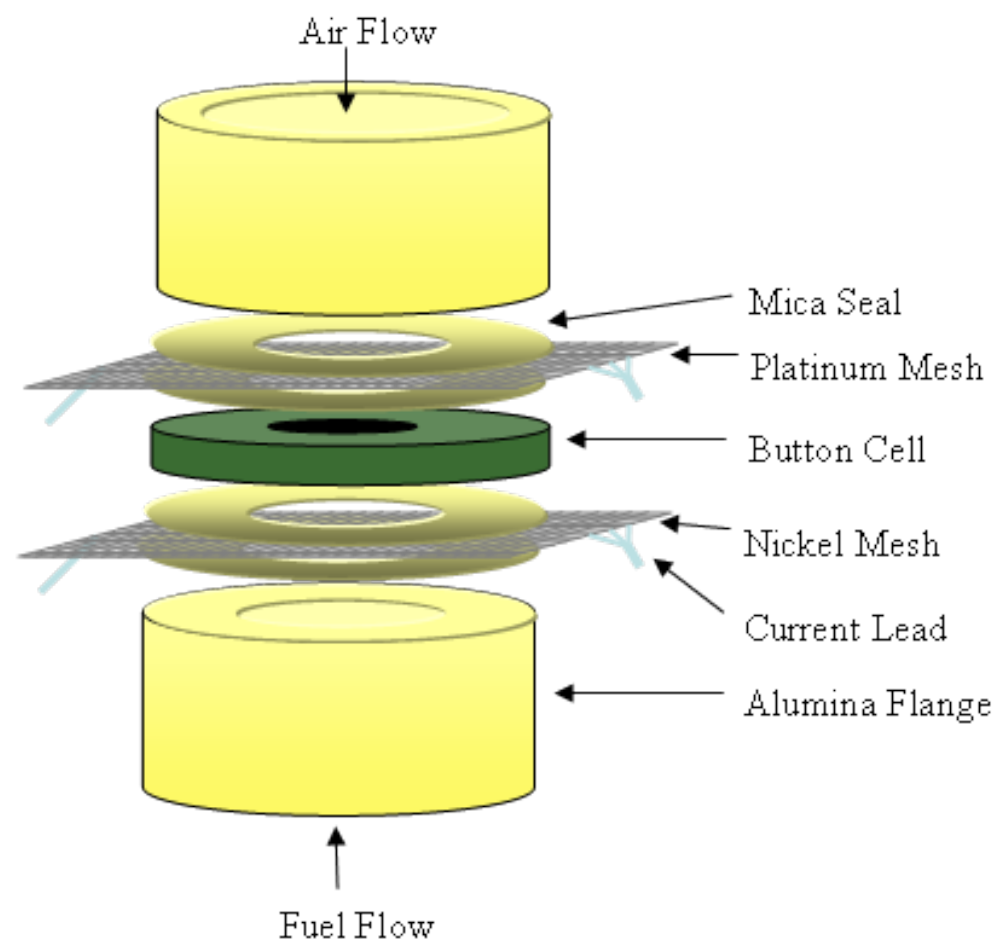

Figure 3.1 - Schematic of SOFC Mounting Apparatus 


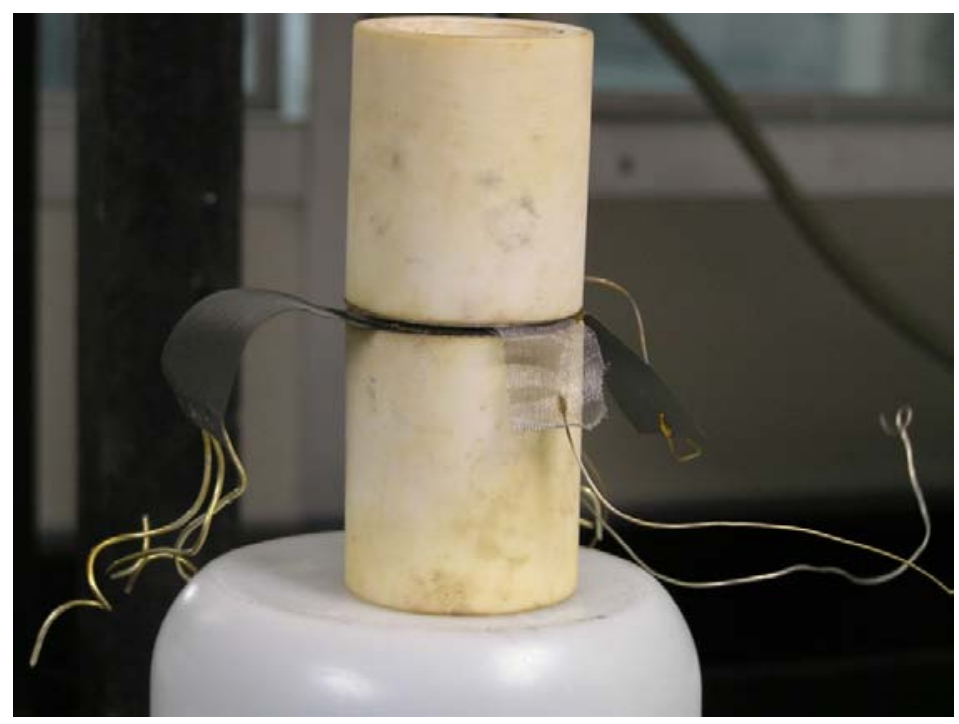

Figure 3.2 - Photograph of mounted cell ready for installation into the test stand for experimentation.

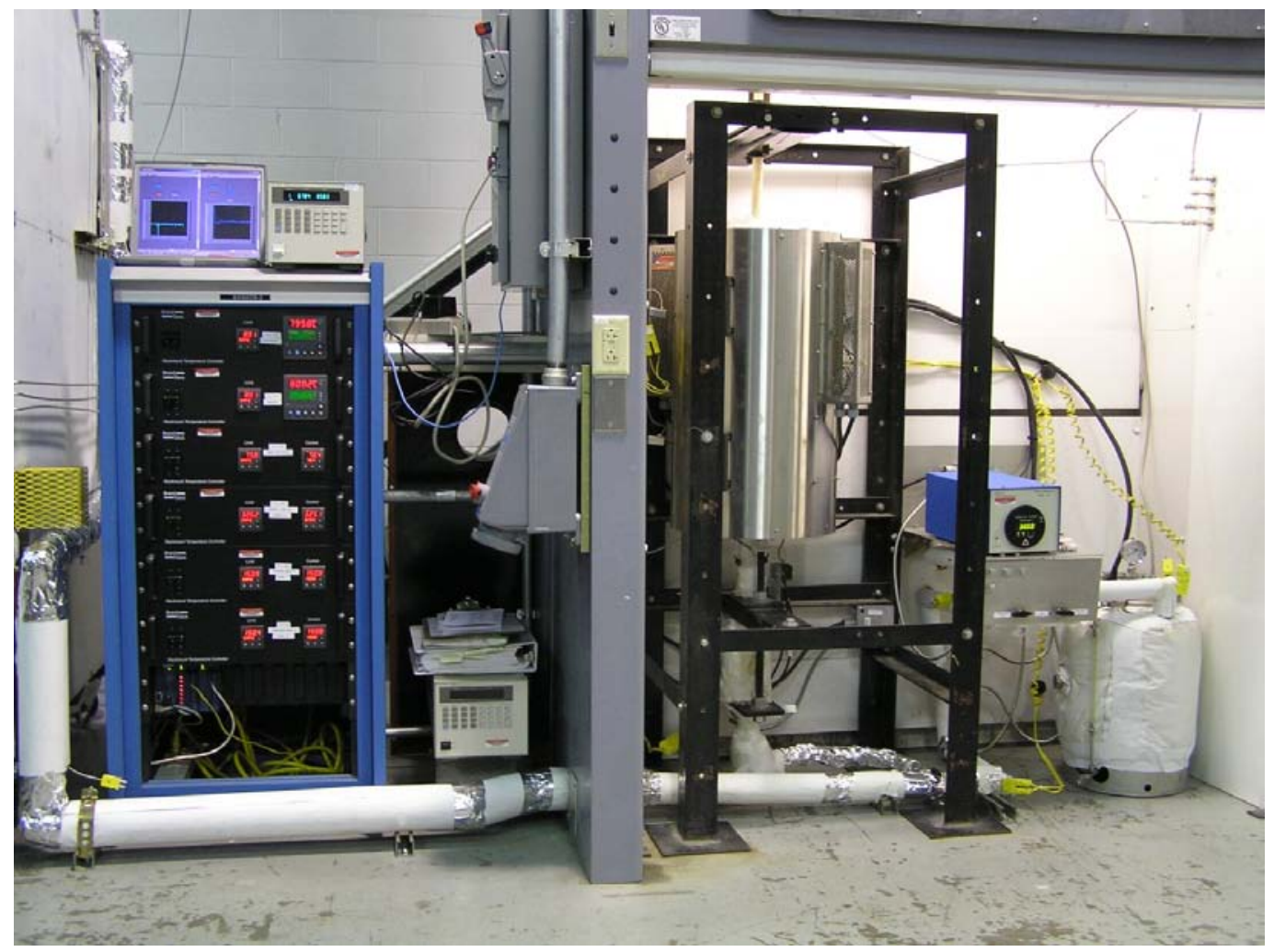

Figure 3.3 - Photograph of entire fuel cell test stand apparatus including (from left) data collection, load bank, temperature controllers, furnace, Dynacalibrator 150, and humidification tank. 


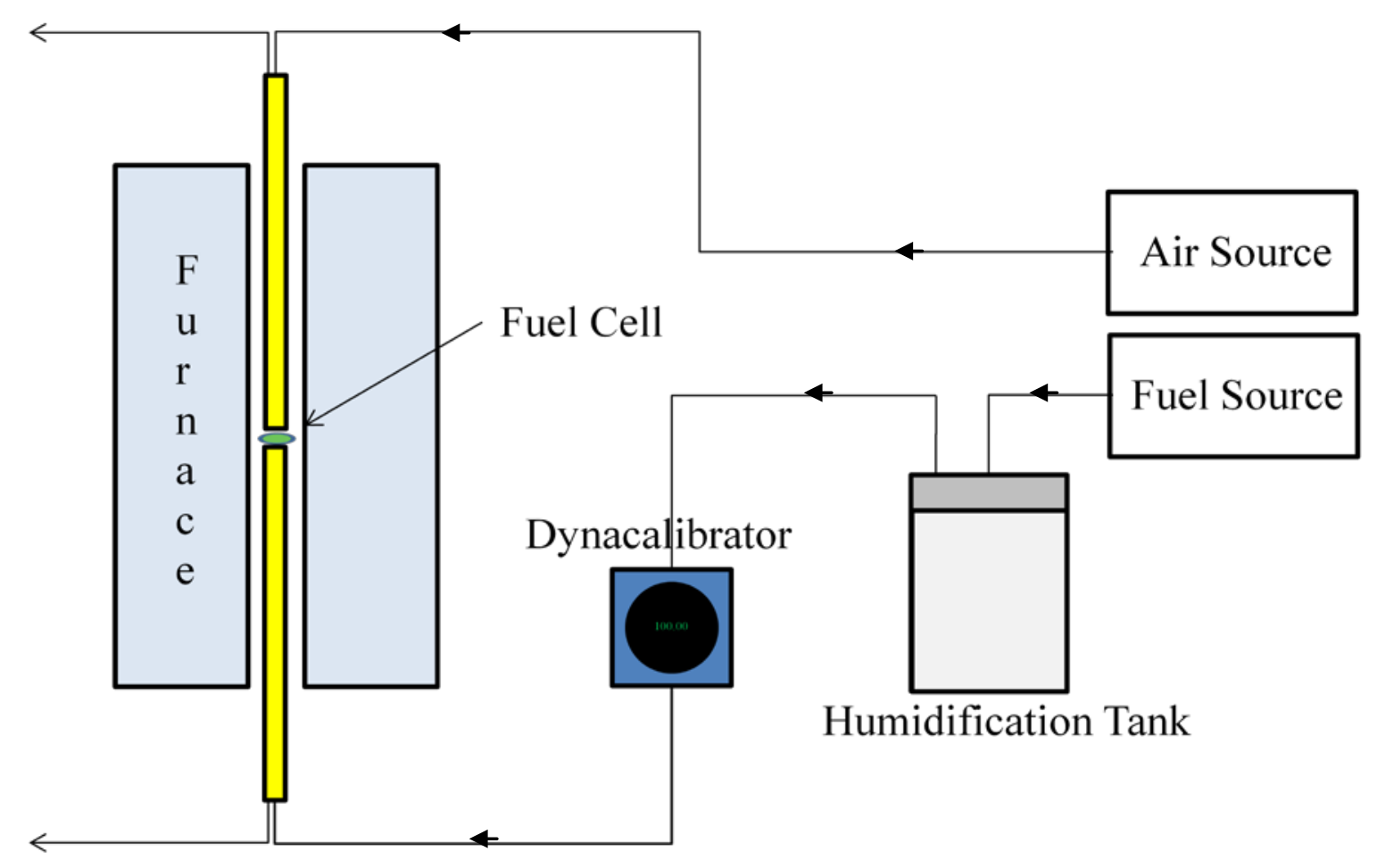

Figure 3.4 - Schematic diagram of flow path. All fuel lines downstream of the humidification tank are heat traced above $150^{\circ} \mathrm{C}$.

\subsection{Experimental Procedure and Analysis}

In each experiment, the system is heated from ambient conditions to $800^{\circ} \mathrm{C}$ over a period of about 5 hours. From room temperature to $500^{\circ} \mathrm{C}$, the ramp rate is $3{ }^{\circ} \mathrm{C} / \mathrm{min}$ and from $500^{\circ} \mathrm{C}$ to $800^{\circ} \mathrm{C}$, the ramp rate decreases to $2^{\circ} \mathrm{C} / \mathrm{min}$. This ensures that there is no thermal shock to the button cell or the ceramic components contained within the furnace. During the heating procedure, $1000 \mathrm{sccm}$ of air is fed to the cathode and $400 \mathrm{sccm}$ of nitrogen is fed to the anode side. Because the humidification tank is in line with the fuel stream, about $3 \%$ water vapor is picked up by the nitrogen feed when the tank is at room temperature.

Once the system has reached its operational temperature, the nickel in the anode side of the button cell is reduced by slowly exposing it to hydrogen. From this point forward, the total fuel flow rate is held to $300 \mathrm{sccm}$. For the first two hours of the reducing period, $10 \%$ hydrogen in 
nitrogen is fed. The second two hours, the anode is exposed to $50 \%$ hydrogen in nitrogen, with the flow increased to pure hydrogen after that. Once a steady OCV has been reached (within 5\% of the predicted Nernst potential at these conditions is deemed acceptable), the cell is operated galvanostatically at $0.25 \mathrm{~A} / \mathrm{cm}^{2}$ for about 12 hours in order to prepare the cell to have current drawn.

After this period, the cell is exposed to syngas in the following procedure. The humidification tank is heated to $76.4^{\circ} \mathrm{C}$ prior to any carbon species being introduced into the fuel stream. The reason for this is to ensure adequate water is present to prevent forming solid carbon deposits due to the Boudouard reaction. Once the tank is at the operating temperature, the operational mixture $\left(\mathrm{H}_{2}-29.1 \% / \mathrm{N}_{2}-3.2 \% / \mathrm{H}_{2} \mathrm{O}-27.1 \% / \mathrm{CO}-28.6 \% / \mathrm{CO}_{2}-12.0 \%\right)$ of syngas is fed to the anode of the button cell and operated galvanostatically at $0.25 \mathrm{~A} / \mathrm{cm}^{2}$ for 48 hours to establish baseline data.

The trace species are then supplied at the desired concentration and the system is operated for the full 500-hour test period. Potential, current, and temperature (cell surface) data are collected over the entire period of the experiment. The cell surface temperature is obtained by placing a thermocouple inside the air feed tube, locating it about 1/8” away from the cell surface. Electrochemical impedance spectra (EIS) are collected periodically over the 500-hour test schedule (usually every 100 hours) to monitor cell performance over the extended test period. EIS spectra are collected using a Solartron 1287 Potentiostat with a Solartron 1260 Frequency Response Analyzer. A two-point, counter and working electrode measurement method is used. An Agilent 7500 series gas chromatograph - inductively coupled plasma / mass spectrometer (GC-ICP/MS) system is used to sample the gas feed before it reaches the anode to ensure the desired concentration of trace species is being supplied to the cell. 
Data are analyzed in several ways to evaluate the performance of the cell. Degradation rates are calculated based on the power reduction over the length of the test. These values are reported as a percentage over 1000 hours of operation in order to be consistent and comparable with other trace species exposure tests. Because several concentrations of each trace species are tested, it is possible to predict a required clean-up level at which a fuel cell will operate as set forth by SECA guidelines ( 3\% / 1000 hours with an operation lifetime of 40,000 hours). Cells are also sent for post-trial analysis by XPS and SEM/EDS.

The XPS system used is a SAM-590 with scanning Auger and XPS capabilities, supplied by Phi RBD Instruments. Charge correction was used in the analysis. The XRD is a PanAnalytical PW-3040 X-Pert Pro with an Omni Focus III analyzer. The SEM is a JEOL-840A interfaced with a Thermoelectric System 6 Microanalysis system.

\section{3. $\quad$ Test Plan}

The specific experimental plan is as follows:

1. Trace metal, Mercury, $1 \mathrm{ppm}, 800^{\circ} \mathrm{C}, 0.25 \mathrm{~A} / \mathrm{cm}^{2}, 500$ hours

2. Trace metal, Mercury, $10 \mathrm{ppm}, 800^{\circ} \mathrm{C}, 0.25 \mathrm{~A} / \mathrm{cm}^{2}, 500$ hours

3. Higher hydrocarbon, Benzene, $15 \mathrm{ppm}, 800^{\circ} \mathrm{C}, 0.25 \mathrm{~A} / \mathrm{cm}^{2}, 500$ hours

4. Higher hydrocarbon, Benzene, $150 \mathrm{ppm}, 800^{\circ} \mathrm{C}, 0.25 \mathrm{~A} / \mathrm{cm}^{2}, 500$ hours

5. Higher hydrocarbon, Naphthalene, $100 \mathrm{ppm}, 800^{\circ} \mathrm{C}, 0.25 \mathrm{~A} / \mathrm{cm}^{2}, 500$ hours

6. Higher hydrocarbon, Naphthalene, $500 \mathrm{ppm}, 800^{\circ} \mathrm{C}, 0.25 \mathrm{~A} / \mathrm{cm}^{2}, 500$ hours

All tests are conducted at the same temperature, current density, with the same syngas composition (before trace species doping), and for the same length of time. Benzene, naphthalene, and mercury are tested at two concentrations in order to generate a percent degradation versus concentration relationship. These tests are sufficient to predict necessary coal syngas trace species cleanup requirements for $40,000 \mathrm{~h}$ power production as well as a detailed mechanism of attack for one of the trace species. 


\subsection{Experimental Safety}

Primary research was conducted at the National Energy Technology Laboratory (NETL) in Morgantown, WV. NETL's Safety Analysis and Review System (SARS), which is a rigorous analysis of the potential hazards associated with an experiment, was followed throughout all experimental work. All instruction and guidelines provided by the SARS document for this project were followed to ensure proper safety procedures. Safety procedures included, but were not limited to: reading all equipment operation manuals, reading and understanding the applicable SARS document, using proper personal protective equipment as required, posting all MSDS data, and following all proper emergency plans and practices as needed. 


\section{CHAPTER FOUR - RESULTS}

\subsection{Mercury Exposure - 1 ppm}

An unreacted SOFC button cell was exposed to simulated coal syngas doped with 1 ppm mercury for 500 hours in Test 1 . Figure 4.1 shows the potential and current as a function of time at an operating temperature of $800^{\circ} \mathrm{C}$. After hydrogen conditioning and current treatment, the OCV was $1.059 \mathrm{~V}$. At $42.4 \mathrm{~h}$, the fuel stream is switched over to syngas and the recorded OCV was $0.953 \mathrm{~V}$. The recorded OCV was $2.6 \%$ lower than $E_{N}(0.978 \mathrm{~V})$ and operation was steady at OCV and under load. This is likely due to minor leaks in the apparatus, allowing some fuel to be combusted instead of electrochemically reacted. The syngas Nernst potential $\left(E_{N}\right)$ is calculated from the $E_{N}$ for pure $\mathrm{H}_{2}$ fuel and for pure $\mathrm{CO}$ fuel, and then assuming a relative electrochemical reaction rate of $3 \mathrm{H}_{2}: 1 \mathrm{CO}$. This estimate accounts for the fact that the WGS reaction will shift $\mathrm{CO}$ to $\mathrm{H}_{2}$, due to the high amount of $\mathrm{H}_{2} \mathrm{O}$ in the fuel stream. The predicted syngas $E_{N}$ falls between the bounds given by the $E_{N}$ for the pure fuels, which are $0.973 \mathrm{~V}$ for $\mathrm{H}_{2}$ and $0.991 \mathrm{~V}$ for CO. At equilibrium, the OCV should fall between these values, but closer to the $\mathrm{H}_{2}$ value. Mercury is supplied to the cell at $102.6 \mathrm{~h}$ into the run, and flows for the duration of the experiment.

Figure 4.2 shows impedance data collected at 102.7 h (clean syngas), 202 h (99 h mercury exposure), 335 h (232 h mercury exposure), 500 h (397 h mercury exposure), and at $596 \mathrm{~h}$ (493 h mercury exposure). Series (ohmic) resistance, $\mathrm{R}_{\mathrm{S}}$, increased from about $0.30 \Omega$ to about $0.55 \Omega$ and the polarization resistance, $R_{P}$, increased from about $0.18 \Omega$ to about $0.22 \Omega$ over the 500 hour test. The impedance data for mercury showed two distinct arches while the hydrocarbon impedance results showed more subtle two-arch curves. 


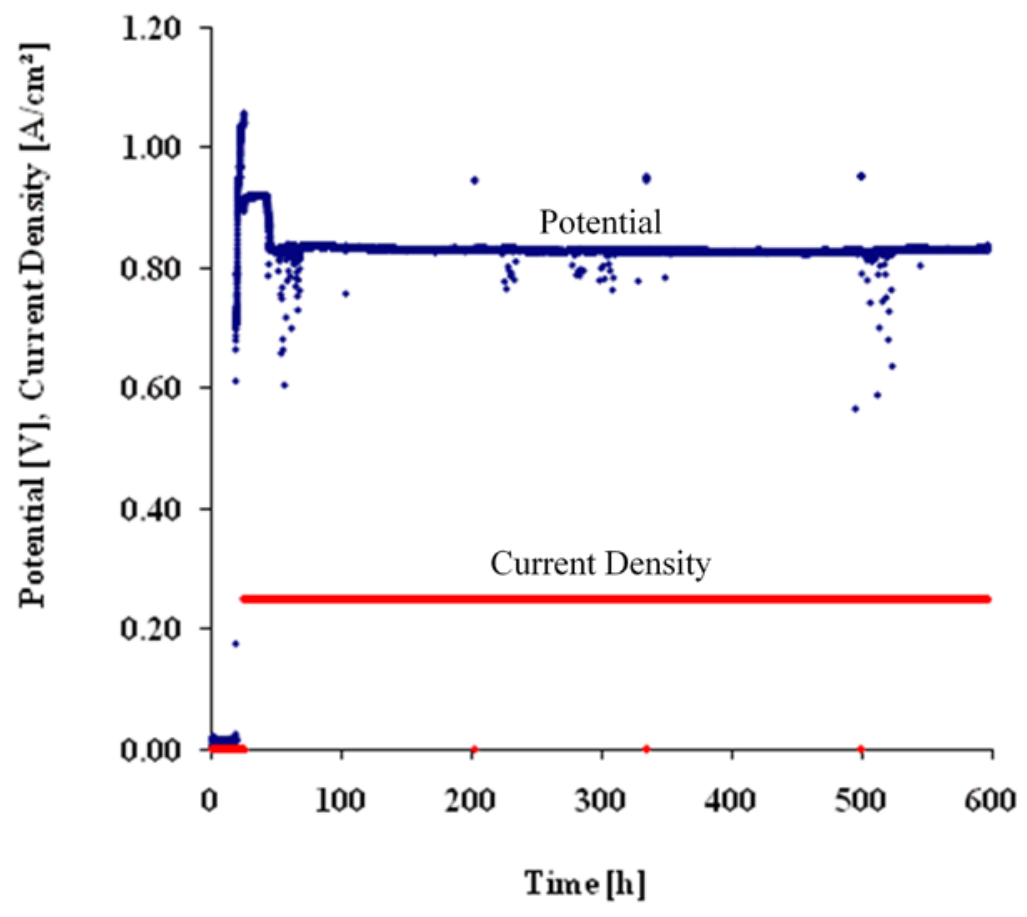

Figure 4.1 - The potential response and current density of a SOFC exposed to syngas doped with 1 ppm mercury for $500 \mathrm{~h}$ at $800^{\circ} \mathrm{C}$.

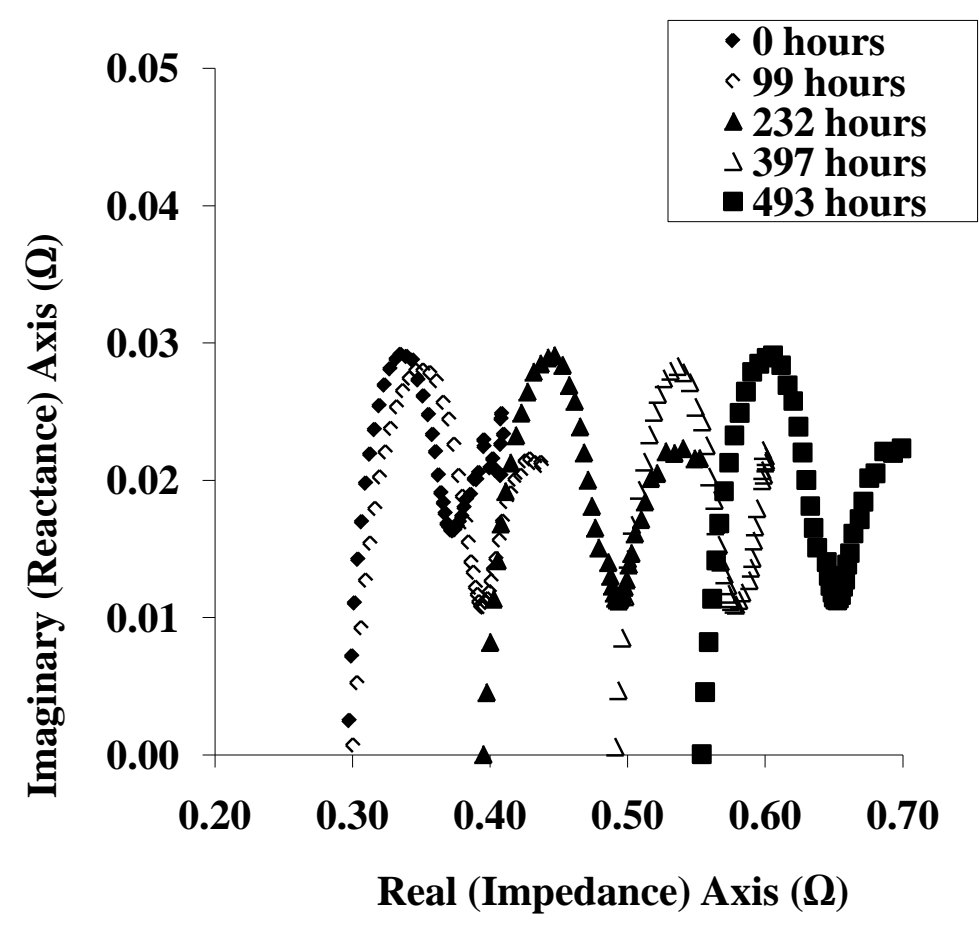

Figure 4.2 - Impedance plots at various times of exposure during the $500 \mathrm{~h}$ operation period of a button cell exposed to syngas doped with $1 \mathrm{ppm}$ mercury at $800^{\circ} \mathrm{C}$. 


\subsection{Mercury Exposure - 10 ppm}

An unreacted button cell was exposed to syngas containing 10 ppm mercury for 500 hours at $800^{\circ} \mathrm{C}$ in Test 2. Figure 4.3 shows the potential and current over time. After hydrogen conditioning and current treatment, the OCV was $1.060 \mathrm{~V}$, which is within $3.6 \%$ of the predicted Nernst potential. At $47.3 \mathrm{~h}$, the fuel stream is switched over to syngas and OCV was $0.942 \mathrm{~V}$. The recorded OCV was $3.7 \%$ lower than $E_{N}$ and operation was steady at OCV and under load. Mercury is supplied to the cell at $95.5 \mathrm{~h}$ into the run, and flows for the duration of the experiment.

Figure 4.4 shows impedance data collected at 95.6 h (clean syngas), 215 h (119 h mercury exposure), and at $602 \mathrm{~h}$ (506 h mercury exposure). $\mathrm{R}_{\mathrm{S}}$ increased from about $0.30 \Omega$ to about 0.38 $\Omega$ and the $\mathrm{R}_{\mathrm{P}}$ increased from about $0.13 \Omega$ to about $0.20 \Omega$ over the 500 -hour test. As in the prior mercury test, two distinct arches are observed in this plot. Figure 4.5 shows that $\mathrm{R}_{\mathrm{P}}$ is increasing slowly over time. The magnitude of the increase is small and does not show any appreciable cell degradation. 


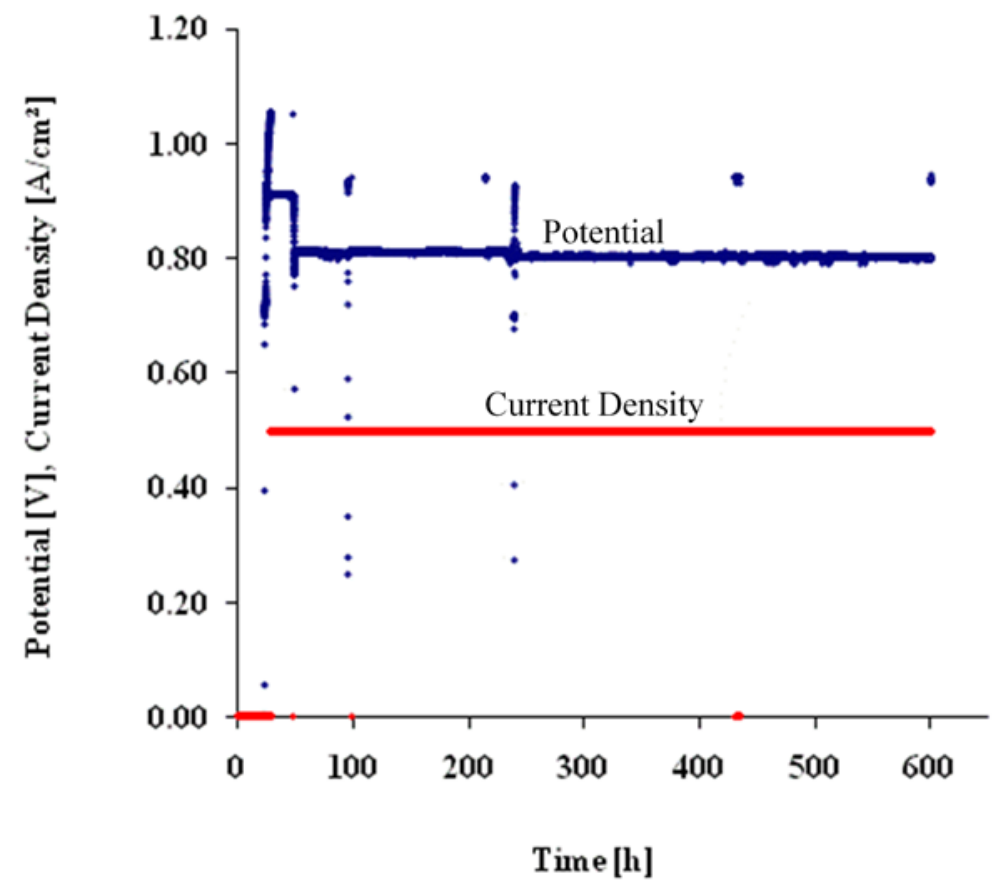

Figure 4.3 - The potential response and current density of a SOFC exposed to syngas doped with $10 \mathrm{ppm}$ mercury for $500 \mathrm{~h}$ at $800^{\circ} \mathrm{C}$.

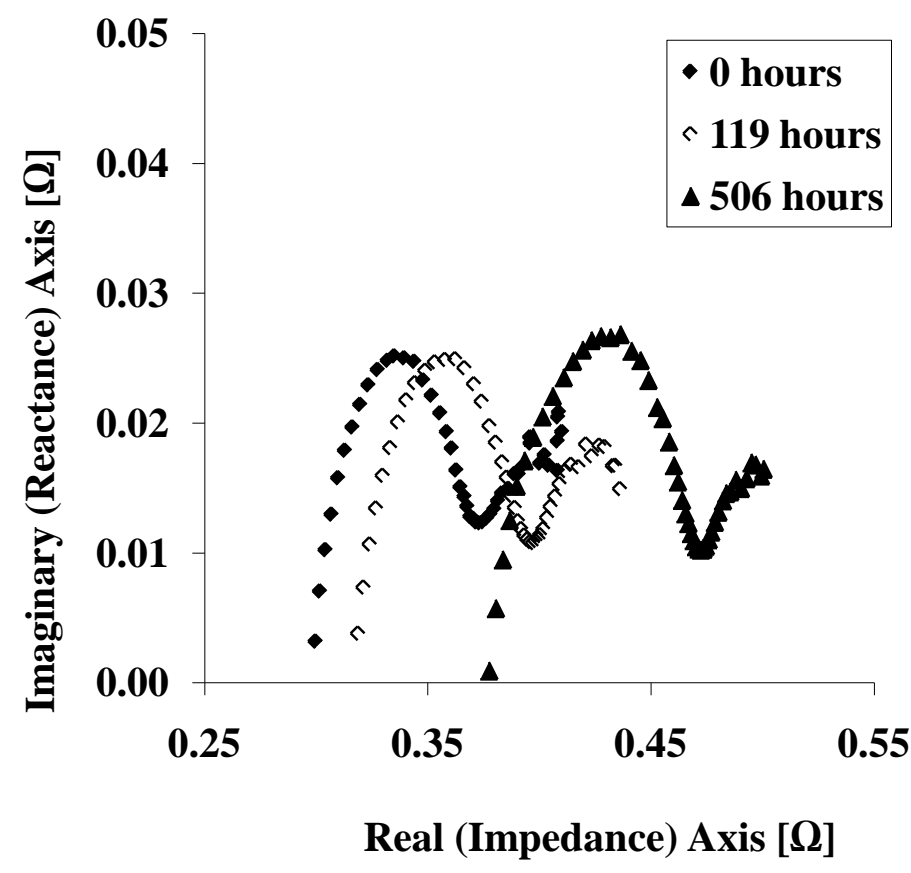

Figure 4.4 - Impedance plots at various times during the $500 \mathrm{~h}$ operation period of a button cell exposed to syngas doped with $10 \mathrm{ppm}$ mercury at $800^{\circ} \mathrm{C}$. 


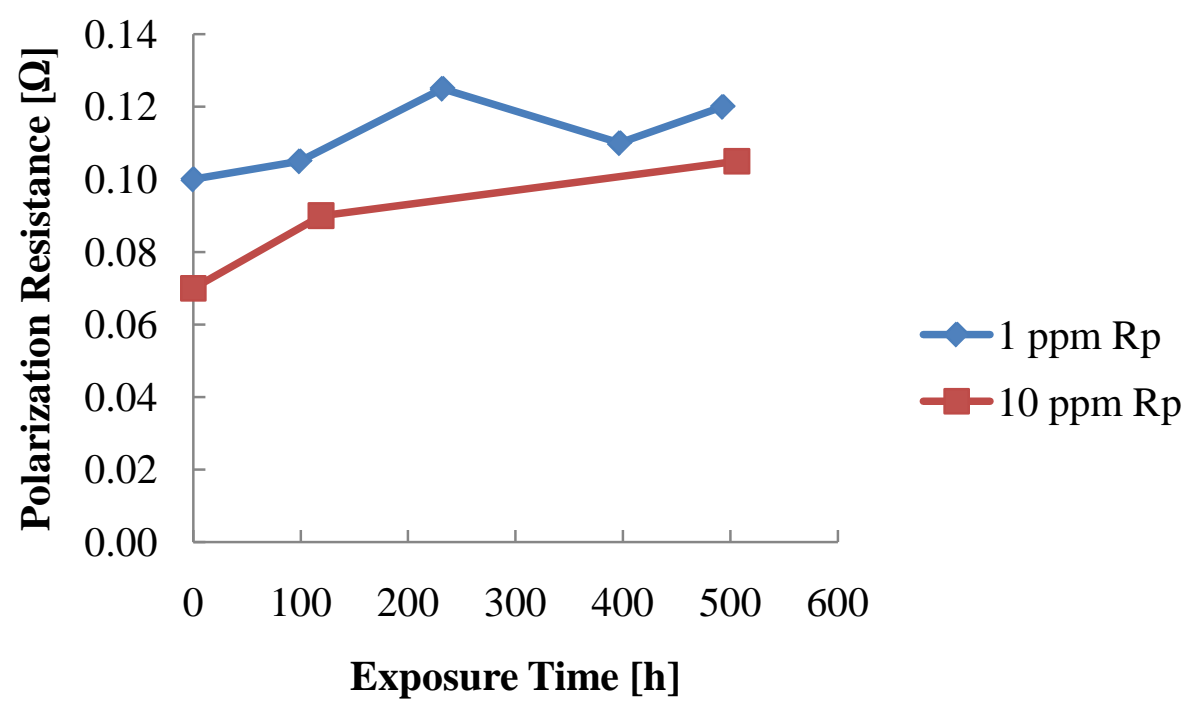

Figure 4.5 - Polarization resistance as a function of time for 1 and $10 \mathrm{ppm}$ mercury exposure. The small magnitude of the resistance increase indicates that no appreciable cell degradation is occurring on this time scale.

\subsection{Benzene Exposure - 15 ppm}

A fresh SOFC button cell was exposed to syngas doped with $15 \mathrm{ppm}$ benzene at $800^{\circ} \mathrm{C}$ during Test 3. Figure 4.6 shows the recorded potential and current as a function of time. The OCV after hydrogen conditioning is $1.065 \mathrm{~V}$, within $3.2 \%$ of the Nernst potential of $1.10 \mathrm{~V}$. The fuel stream was switched over to syngas and OCV was recorded at $0.945 \mathrm{~V}$, which is $3.4 \%$ less than the predicted Nernst value of $0.978 \mathrm{~V}$. Benzene is supplied to the cell at $116.6 \mathrm{~h}$ into the run and flows for the duration of the experiment.

Impedance data are collected at OCV at $116.7 \mathrm{~h}$ (clean syngas), $383 \mathrm{~h}$ (266 h benzene

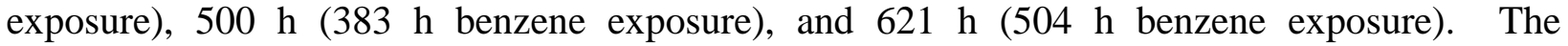
impedance plot shown in Figure 4.7 shows $\mathrm{R}_{\mathrm{S}}$ decreasing from $0.62 \Omega$ to $0.35 \Omega$ and then increasing to $0.41 \Omega$. $\mathrm{R}_{\mathrm{P}}$ remained constant at about $0.10 \Omega$ for the duration of the test. These impedance results are deemed not reliable because of the sporadic jumps in the ohmic resistance. 
This was traced to a poor connection during a few of the analyses, resulting in an artificially high ohmic resistance.

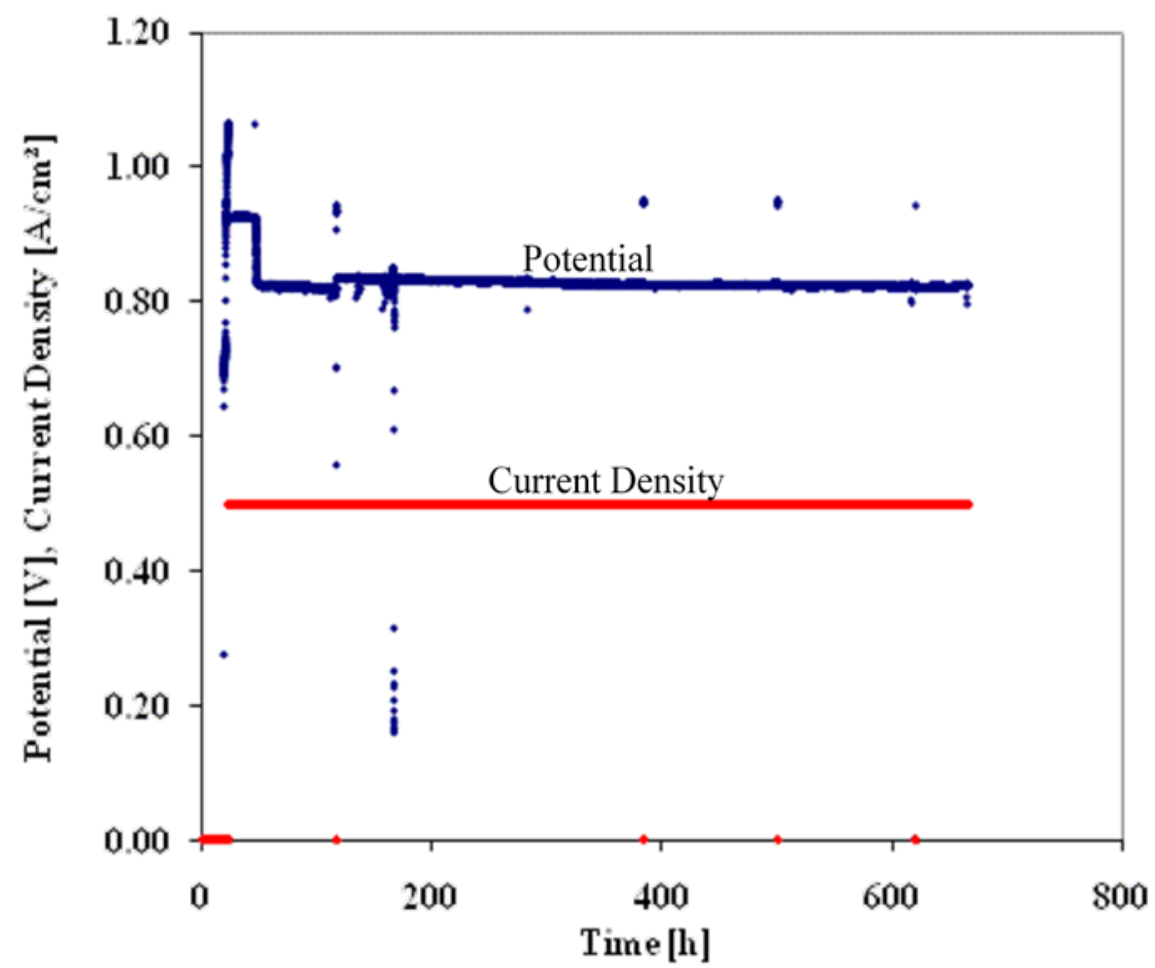

Figure 4.6 - The potential response and current density of a SOFC exposed to syngas doped with 15 ppm benzene for $500 \mathrm{~h}$ at $800^{\circ} \mathrm{C}$. 


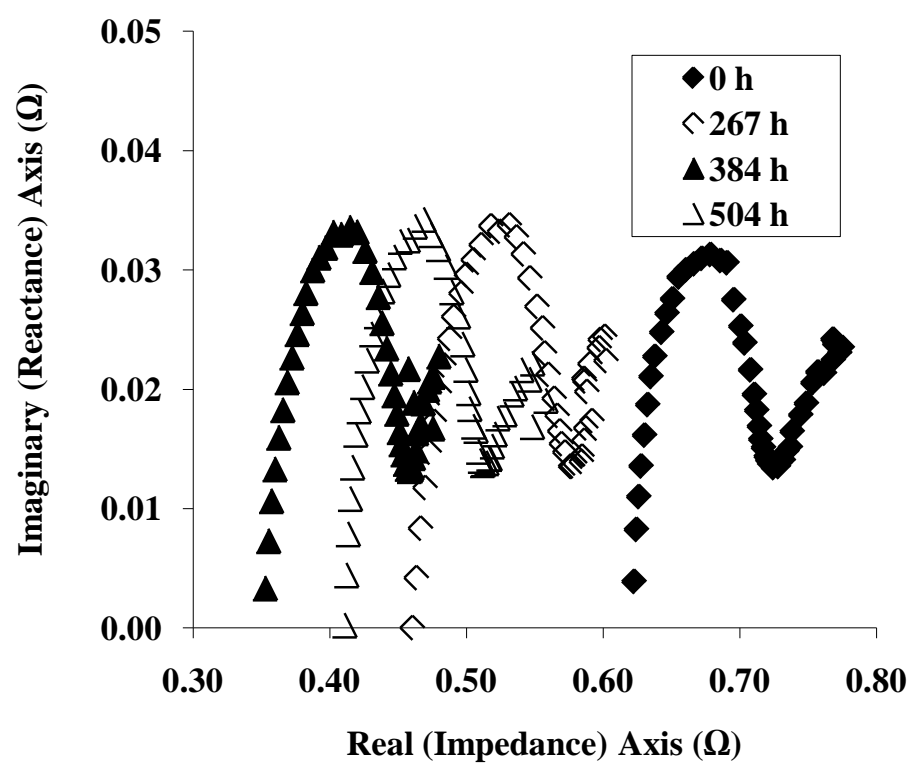

Figure 4.7 - Impedance plots at several times during the $500 \mathrm{~h}$ operation period of a button cell exposed to syngas doped with $15 \mathrm{ppm}$ benzene at $800^{\circ} \mathrm{C}$.

\subsection{Benzene Exposure - 150 ppm}

A new SOFC button cell was exposed to syngas doped with $150 \mathrm{ppm}$ benzene at $800^{\circ} \mathrm{C}$ during Test 4. Figure 4.8a shows the recorded potential and current as a function of time. The OCV after hydrogen conditioning is $1.057 \mathrm{~V}$, within $4.0 \%$ of the Nernst potential of $1.10 \mathrm{~V}$. The fuel stream was switched over to syngas and OCV was recorded at $0.947 \mathrm{~V}$, which is about $3.2 \%$ less than the predicted Nernst value of $0.978 \mathrm{~V}$. Benzene is supplied to the cell at $95.8 \mathrm{~h}$ into the run and flows for the duration of the experiment.

Impedance data are collected at OCV at $95.8 \mathrm{~h}$ (clean syngas), $213 \mathrm{~h}$ (117 h benzene exposure), and $383 \mathrm{~h}$ (287 h benzene exposure). The impedance plot shown in Figure 4.8b shows the ohmic (series) resistance $\left(\mathrm{R}_{\mathrm{S}}\right)$ increasing from $0.27 \Omega$ to $0.33 \Omega$. The polarization resistance $\left(R_{P}\right)$ remains constant at about $0.12 \Omega$ for the duration of the test. Figure 4.10 shows the $\mathrm{R}_{\mathrm{P}}$ as a function of time. The change in the resistance is negligible, indicating that little degradation occurred that effected the polarization resistance. 


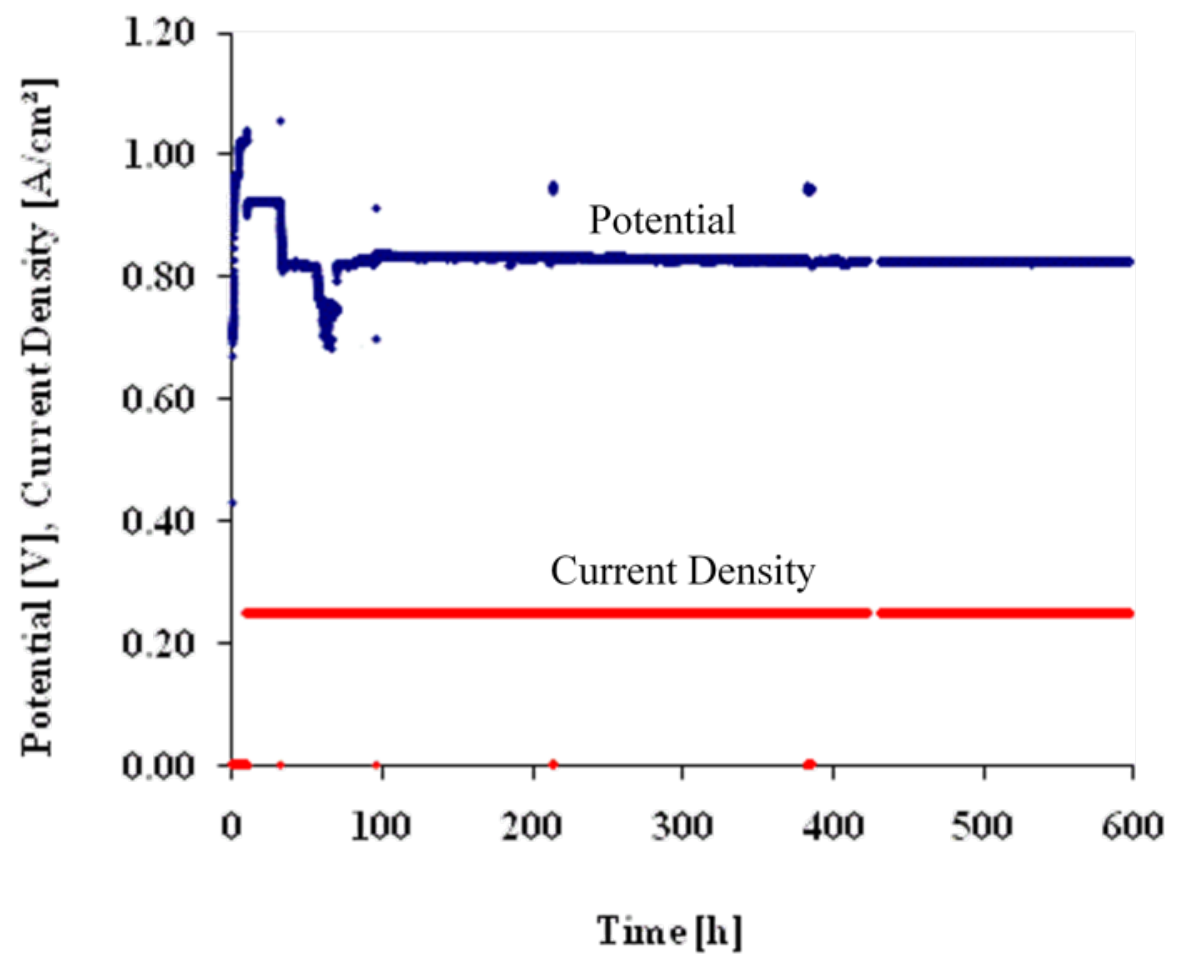

Figure 4.8 - The potential response and current density of a button cell exposed to syngas doped with 150 ppm benzene for $500 \mathrm{~h}$ at $800^{\circ} \mathrm{C}$.

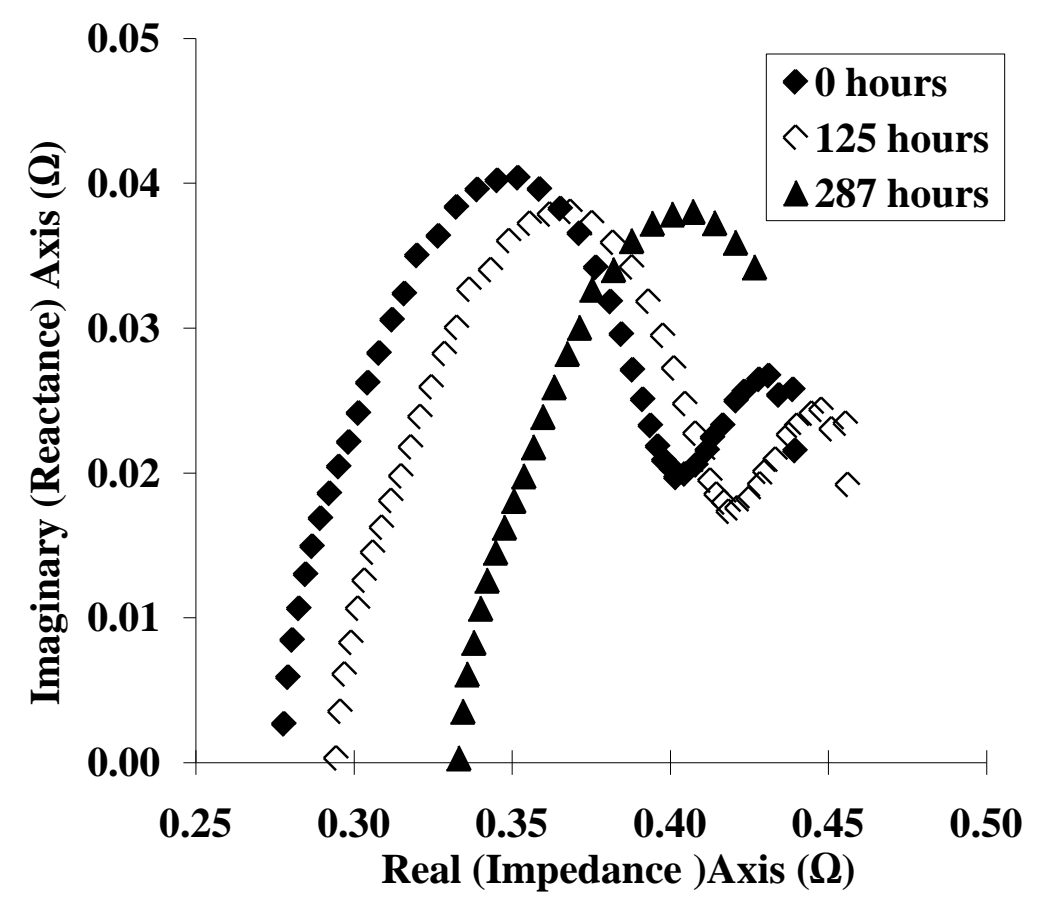

Figure 4.9 - Impedance plots at various times during the $500 \mathrm{~h}$ operation period of a button cell exposed to syngas doped with $150 \mathrm{ppm}$ benzene at $800^{\circ} \mathrm{C}$. 


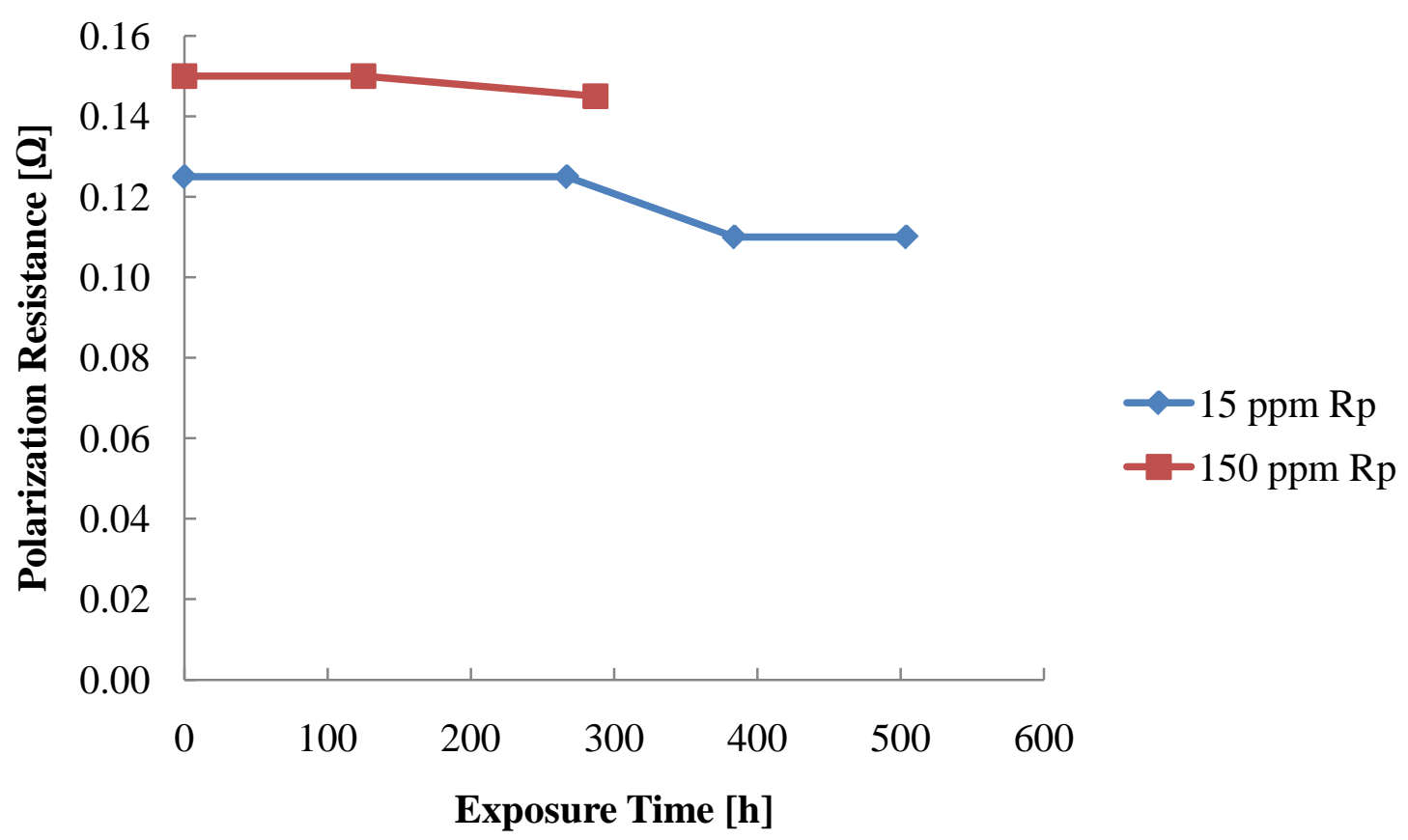

Figure 4.10 - Polarization resistance as a function of time for 15 and $150 \mathrm{ppm}$ benzene exposure. In this case, the change in resistance is negligible, indicating that minimal cell degradation is occurring.

\subsection{Naphthalene Exposure - 100 ppm}

An unreacted SOFC button cell was exposed to syngas doped with $100 \mathrm{ppm}$ naphthalene at $800^{\circ} \mathrm{C}$ in Test 5.

Figure 4.11 shows the potential and current versus time. As in previous experiments, the cell is reduced in hydrogen and current treated at $0.250 \mathrm{~A} / \mathrm{cm}^{2}$. The OCV after hydrogen conditioning is $1.079 \mathrm{~V}$, which is within $2.0 \%$ of the predicted Nernst potential. At $29.0 \mathrm{~h}$ into the run, the fuel stream is switched over to syngas and the recorded OCV was $0.960 \mathrm{~V}$. This compared within $1.8 \%$ of the predicted Nernst value of $0.978 \mathrm{~V}$. Naphthalene is supplied to the cell at $98.0 \mathrm{~h}$ into the run, and flows for the duration of the experiment.

Figure 4.12 shows impedance data collected at $98 \mathrm{~h}$ (clean syngas), $242 \mathrm{~h}$ (144 h of naphthalene exposure), $338 \mathrm{~h}$ (240 h of naphthalene exposure), $434 \mathrm{~h}$ (336 h of naphthalene 
exposure), and at $482 \mathrm{~h}$ (384 h of naphthalene exposure). $\mathrm{R}_{\mathrm{S}}$ decreases from about $0.58 \Omega$ to about $0.35 \Omega$ and the $\mathrm{R}_{\mathrm{P}}$ increased from about $0.35 \Omega$ to about $0.50 \Omega$ over the 500 -hour test.

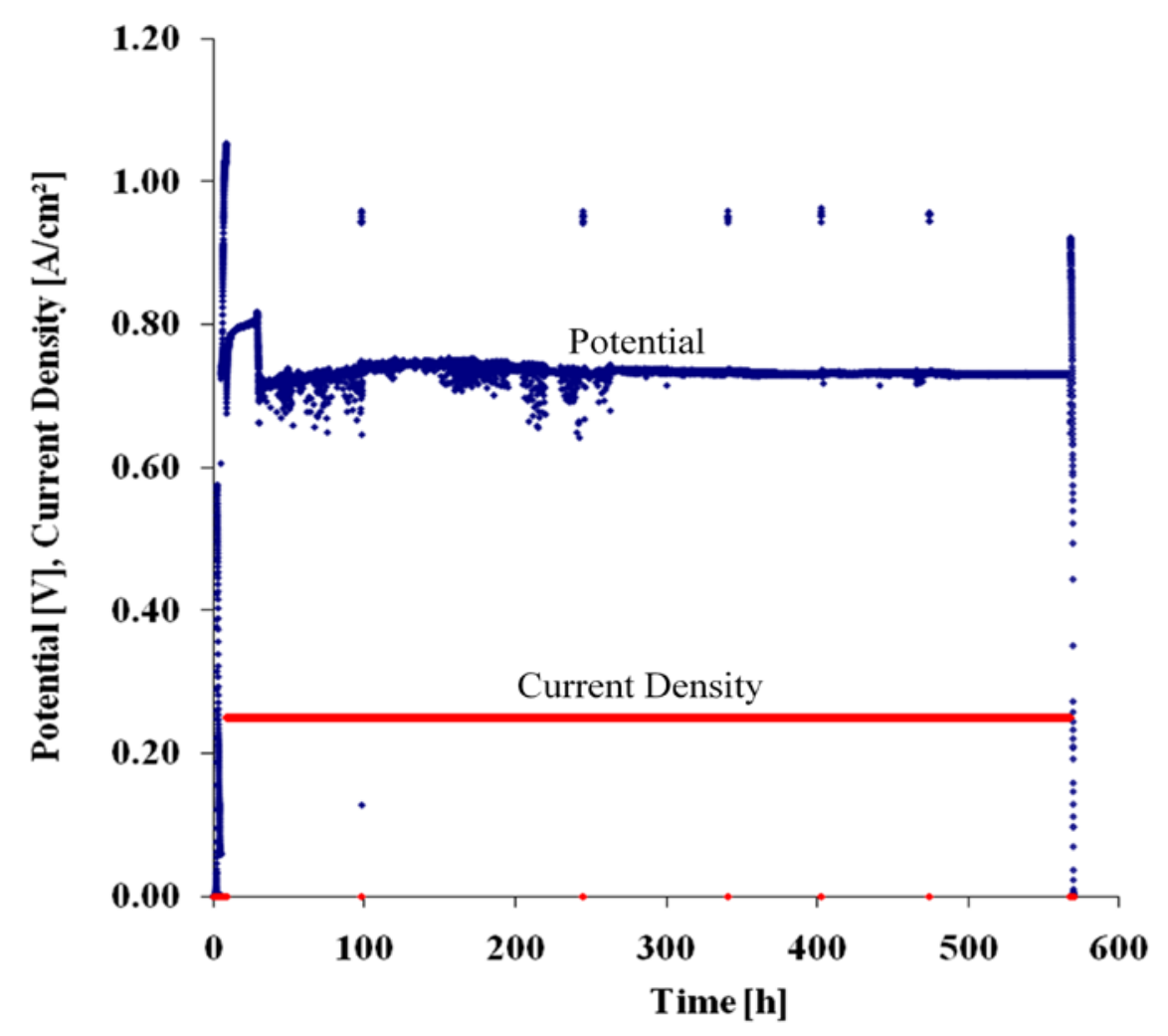

Figure 4.11 - The potential response and current density of a button cell exposed to syngas doped with 100 ppm naphthalene for $500 \mathrm{~h}$ at $800^{\circ} \mathrm{C}$. 


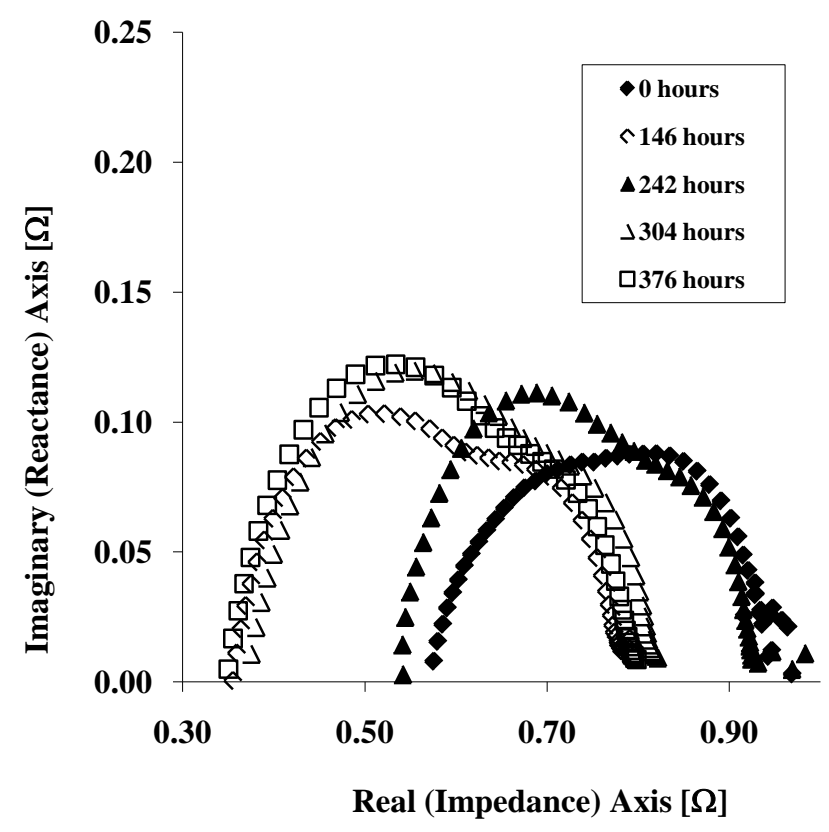

Figure 4.12 - Impedance plots at various times during the $500 \mathrm{~h}$ operation period of a button cell exposed to syngas doped with $100 \mathrm{ppm}$ naphthalene at $800^{\circ} \mathrm{C}$.

\subsection{Naphthalene Exposure -500 ppm}

A fresh button cell was exposed to syngas containing $500 \mathrm{ppm}$ naphthalene at $800^{\circ} \mathrm{C}$ in Test 6. Figure 4.13 shows the potential and current over time. After hydrogen conditioning and current treating the OCV was $1.032 \mathrm{~V}$. Although the recorded OCV is $6.2 \%$ below the $\mathrm{E}_{\mathrm{N}}$, the loaded cell performance was sufficient to continue with the test. At $25.8 \mathrm{~h}$ into the run, the fuel stream was switched over to syngas and the OCV was $0.926 \mathrm{~V}$. This potential is $5.3 \%$ lower than $E_{N}$, however operation was steady at OCV and under load. Naphthalene is supplied to the cell at $152.1 \mathrm{~h}$ into the run, and flows for the duration of the experiment.

Figure 4.14 shows impedance data collected at $151 \mathrm{~h}$ (clean syngas), $246 \mathrm{~h}$ (93 h of naphthalene exposure), $336 \mathrm{~h}$ (184 h of naphthalene exposure), $484 \mathrm{~h}$ (332 h of naphthalene exposure), $578 \mathrm{~h}$ (426 h of naphthalene exposure), and at $651 \mathrm{~h}$ (499 h of naphthalene exposure). $\mathrm{R}_{\mathrm{S}}$ ranged from about $0.28 \Omega$ to about $0.55 \Omega$ and the $\mathrm{R}_{\mathrm{P}}$ increased from about $0.21 \Omega$ to about 
$0.40 \Omega$ over the 500 -hour test. These resistance increases are significant compared to those seen for the benzene and mercury exposure. Figure 4.15 shows polarization increase as a function of time, indicating that modest cell degradation is occurring due to naphthalene exposure.

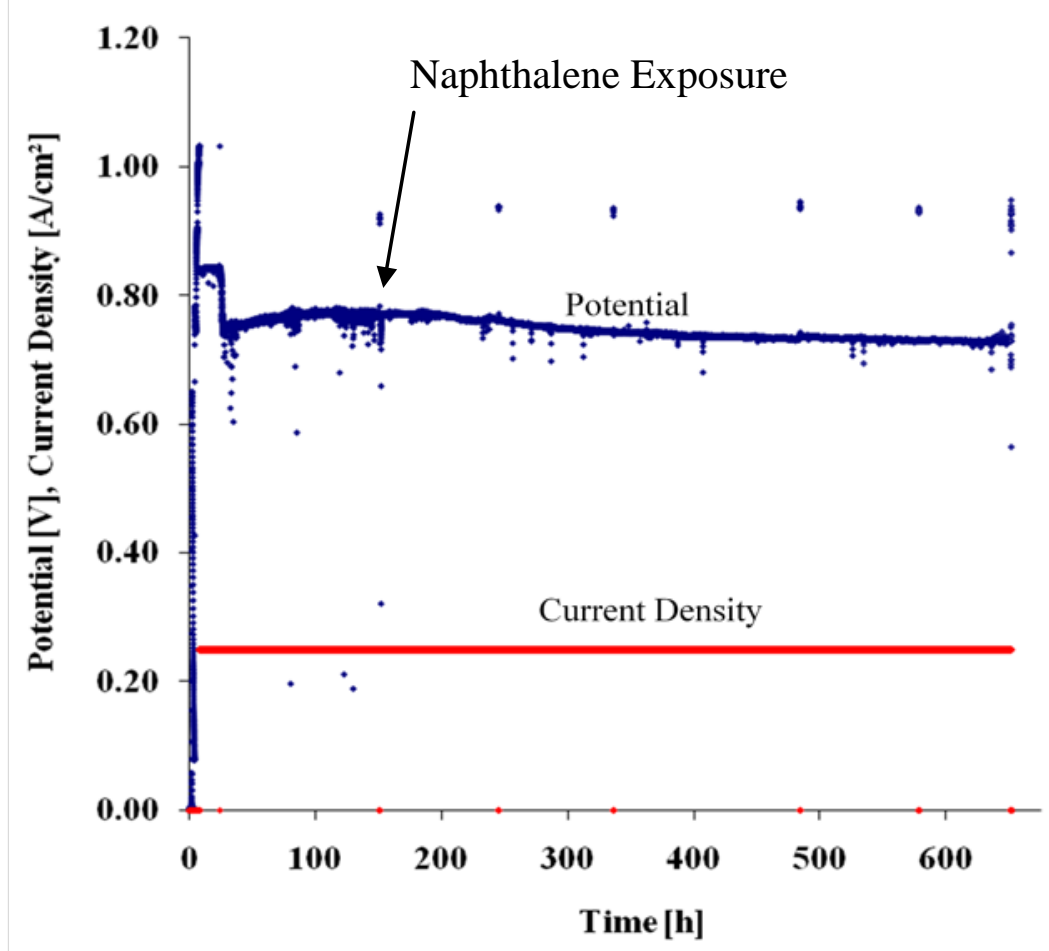

Figure 4.13 - The potential response and current density of a button cell exposed to syngas doped with $500 \mathrm{ppm}$ naphthalene for $500 \mathrm{~h}$ at $800^{\circ} \mathrm{C}$. 


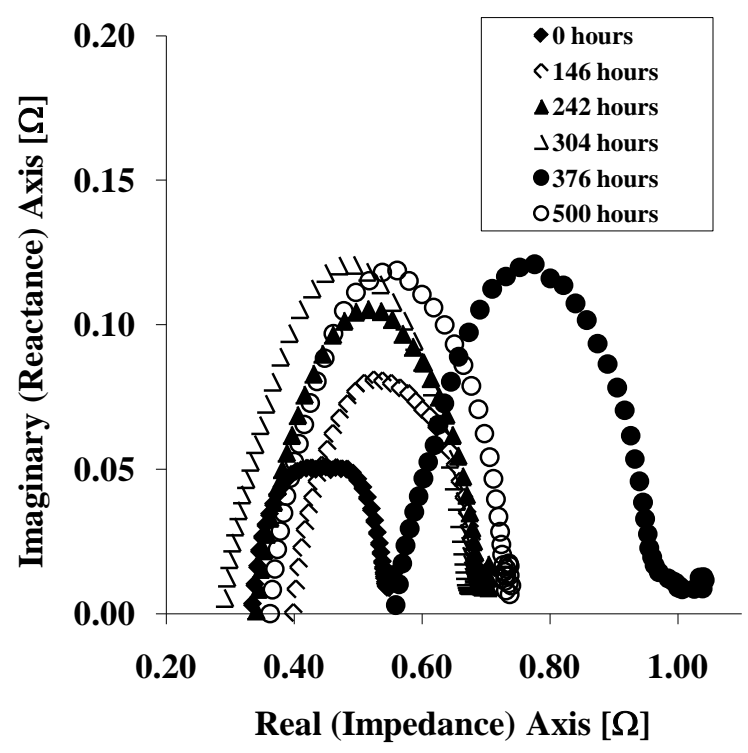

Figure 4.14 - Impedance plots at various times during the $500 \mathrm{~h}$ operation period of a button cell exposed to syngas doped with $500 \mathrm{ppm}$ naphthalene at $800^{\circ} \mathrm{C}$.

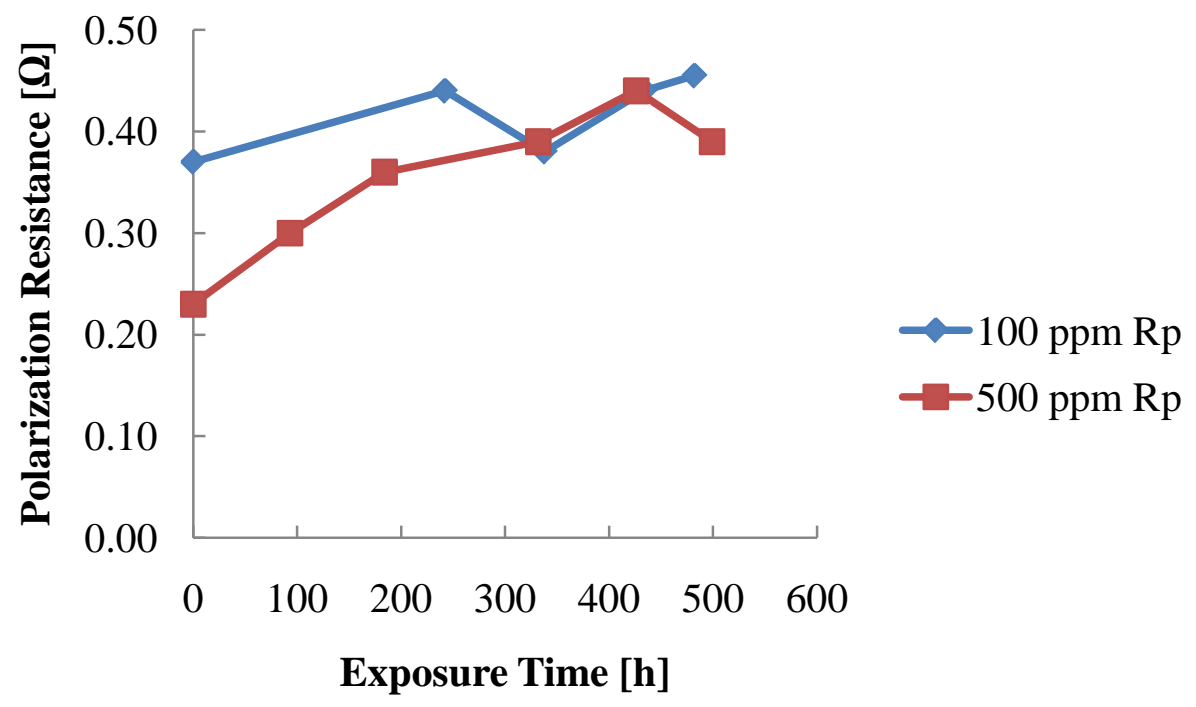

Figure 4.15 - Polarization resistance as a function of time for 100 and $500 \mathrm{ppm}$ naphthalene exposure. Resistance increase indicates a modest degradation in cell performance.

\section{7. $\quad$ Post-trial Analysis}

Post-trial analysis by XPS and SEM was conducted for each exposed button cell. For most runs, the analyses did not show any appreciable amount of carbon deposition on the anode surface. The unreacted fuel cell contained 65\% O, 14\% C, 12\% Zr, 3\% Y, and 3\% Ni (atomic 
\%). These data are reasonable because an unreacted cell has not been reduced, so there are many oxide species at the cell surface. Carbon is likely due to environmental contamination. SEM photographs of the cross-sectional area of a clean, unreacted (not reduced) cell at two levels of magnification are given in Figure 4.16. This figure shows the porous Ni-YSZ anode (top) above the smooth electrolyte and then the dense LSM cathode. The layers can be seen clearly in Figure 4.16b.
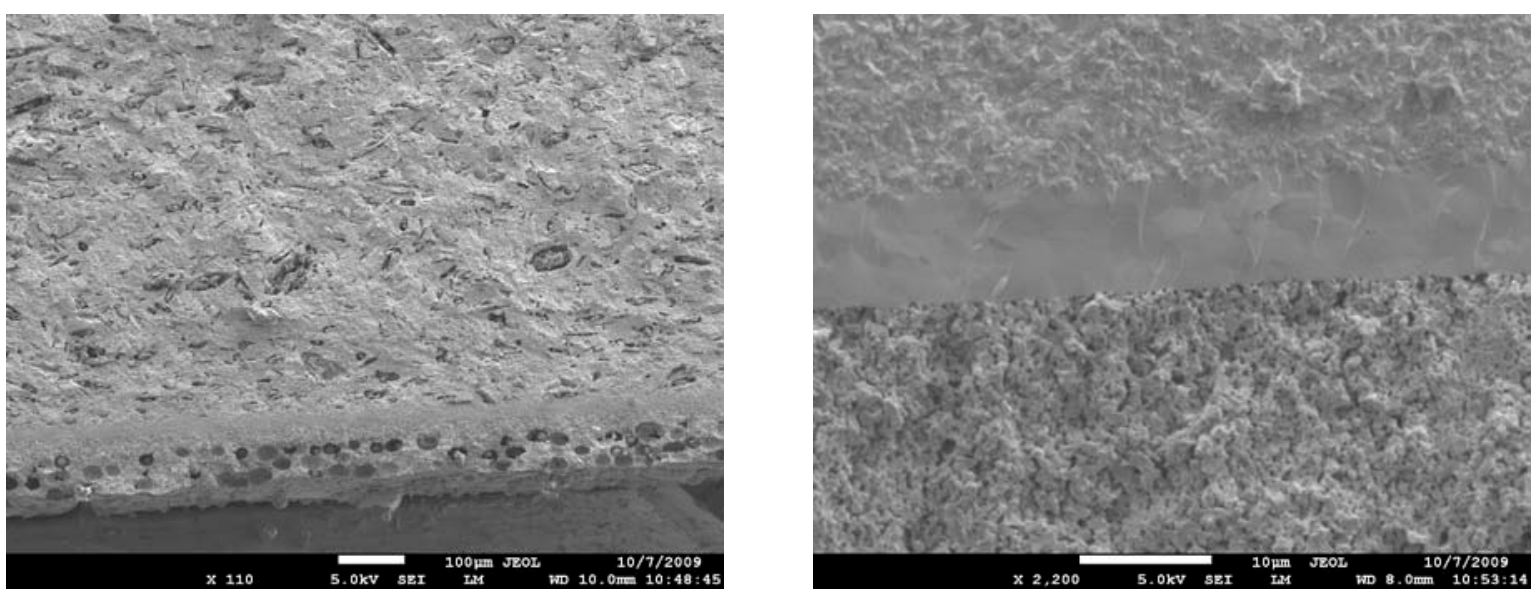

Figure 4.16 - Scanning electron microscope picture of the cross section an unreacted SOFC button cell. Magnification at 110x (a) and 2,200x (b).

X-ray photoelectron spectroscopy (XPS) is a surface analysis technique, which is based upon the photoelectric effect. XPS is chosen as an analytical method because it provides information on near-surface regions due to limited escape depth of the photoelectrons. When an X-ray beam is directed to the sample surface, the energy of the X-ray photon is adsorbed completely by the core electron of an atom. If the photon energy is large enough, then the core electron will escape from the atom and be emitted out of the surface. The emitted electron is referred to as a photoelectron. The binding energies of electrons in the core levels are affected by the chemical state of the respective element. Therefore, the core level shifts provide both an identification of 
the elements involved in chemical surface reactions and the changes in the chemical binding states. In addition, binding energy shifts are caused by processes like cluster size effects or surface rearrangements.

SEM and XPS analysis on the button cells exposed to 1 and $10 \mathrm{ppm}$ mercury did not show any carbon deposition above background nor any mercury on the anode surface. The GCICP/MS was able to detect that mercury was indeed flowing to the fuel cell, however, the amount was not able to be quantified. The isotopic "fingerprint" of mercury obtained from an injected fuel sample is given as Figure 4.17. The isotopic fingerprint refers to the relative natural abundances of each isotope for an element. For example, mercury has isotopes (with relative composition in mole percent) of 196 (0.2\%), 198 (10.0\%), 199 (16.9\%), 200 (23.1\%), 201 (13.2\%), 202 (29.9\%), and 204 (6.9\%). The boxes are the expected ratios based upon ${ }^{200} \mathrm{Hg}$, and the lines are the detected amounts. As can be seen, the results are in good agreement with the known values, proving that mercury is indeed present in the fuel stream. 


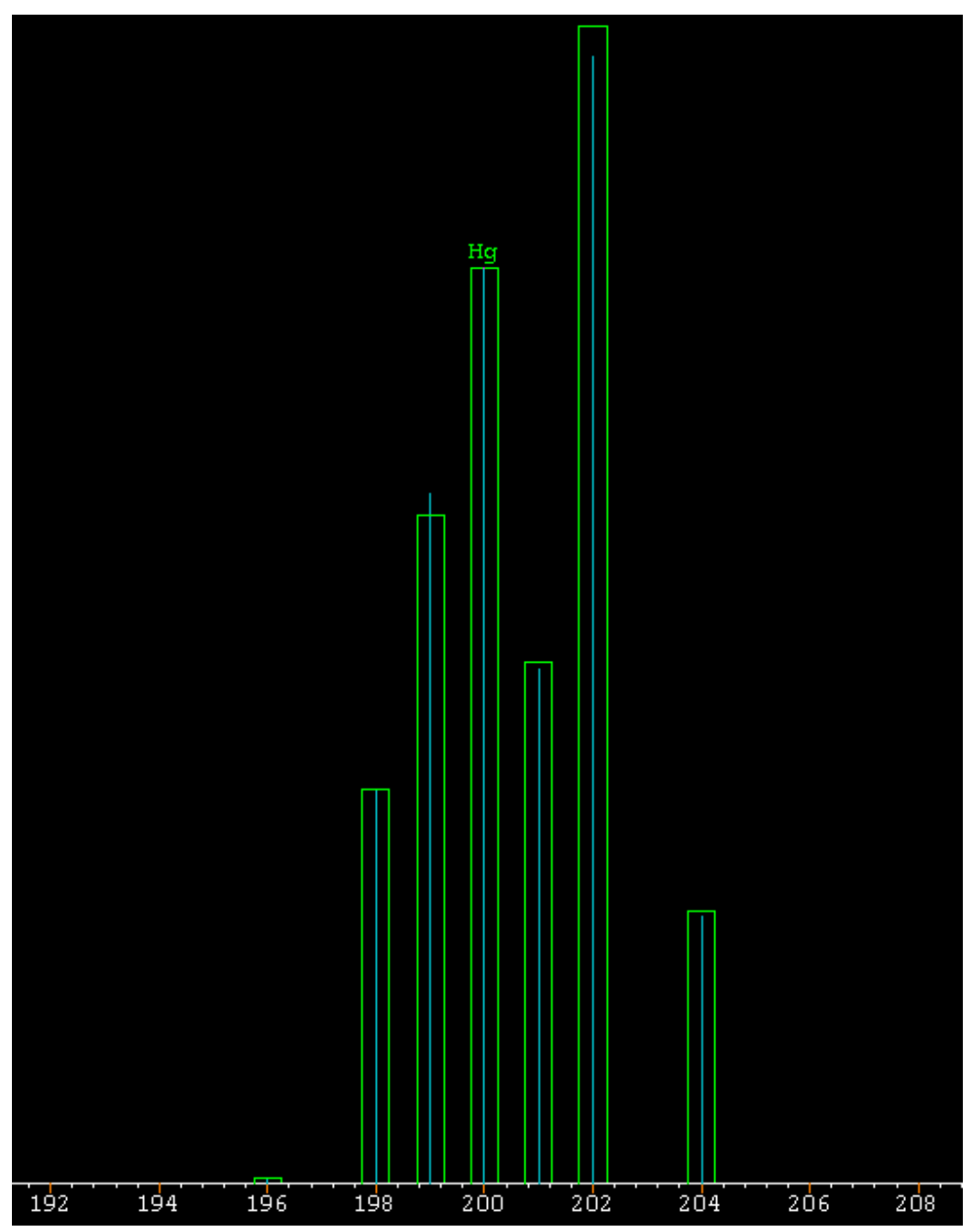

Figure 4.17 - Isotopic fingerprint for mercury detected by GC-ICP/MS in fuel flow upstream of fuel cell.

The button cell exposed to 15 ppm benzene was quenched in nitrogen to room temperature over 15 min and inspected after the 500 h test was completed. The reason for cooling with this method was to capture any carbon that was in the fuel cell. A slow cool-down would have oxidized or gasified any carbon on the surface. However, there was no visible evidence of carbon deposition on the anode surface, the cell was intact and unmarred, and no other notable signs of damage were recorded. The binding energy for adventitious (graphitic) carbon is 284.8 
$\mathrm{eV}$. The relative intensity of the $284.8 \mathrm{eV}$ peak is not enough to determine that graphitic carbon is present above background noise levels. The XPS analysis result is shown in Figure 4.18.

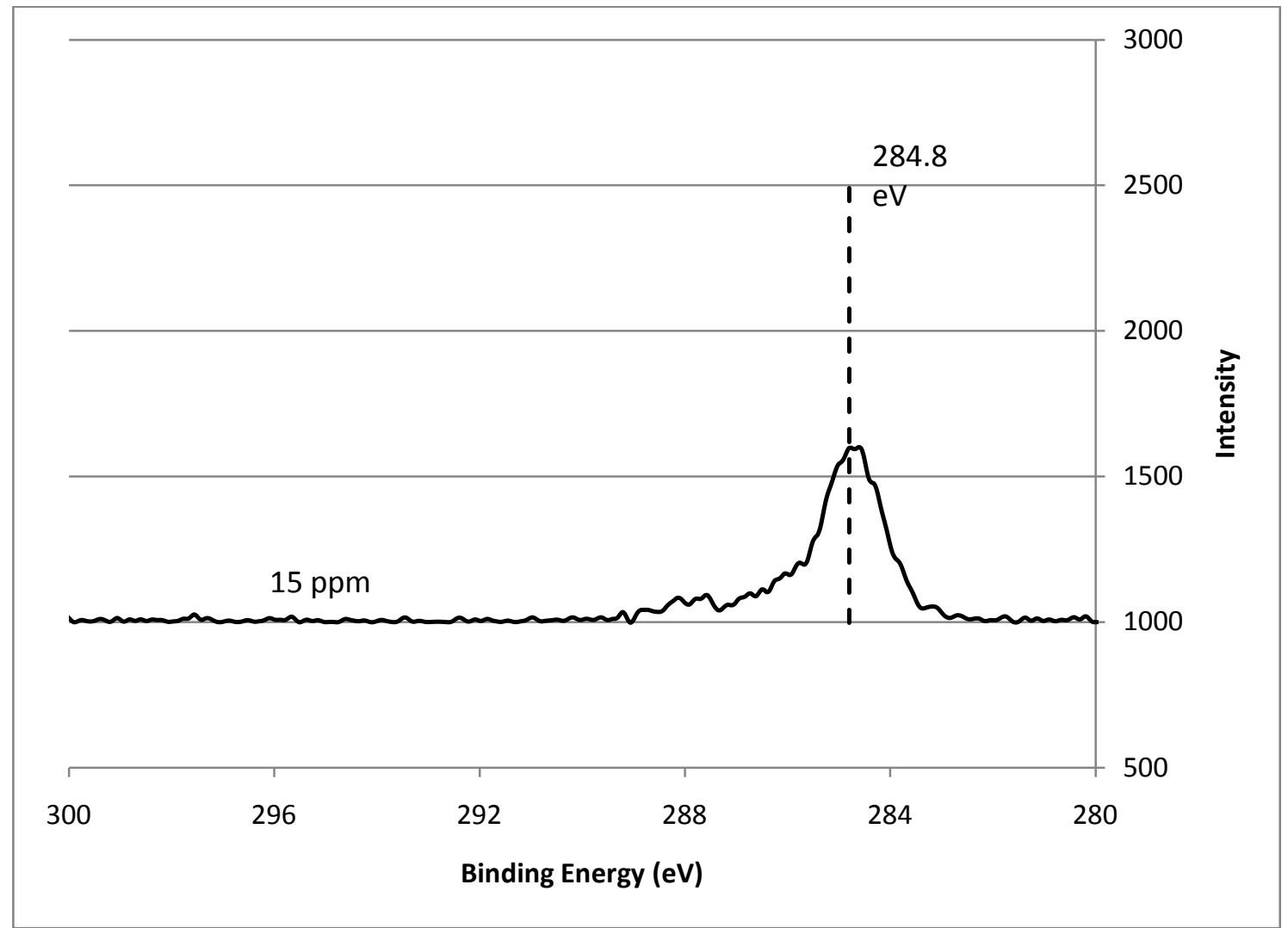

Figure 4.18 - XPS results of carbon for a button cell exposed to $15 \mathrm{ppm}$ benzene for $500 \mathrm{~h}$ at $800^{\circ} \mathrm{C}$. Graphitic carbon has a binding energy of $284.8 \mathrm{eV}$. The peak is not larger than the observed noise levels.

The button cell exposed to 150 ppm benzene was also cooled down by a different method in an attempt to precipitate any adsorbed carbon in the form of nickel carbide $\left(\mathrm{Ni}_{3} \mathrm{C}\right)$. The cell was quenched in dry nitrogen from $800^{\circ} \mathrm{C}$ to $300^{\circ} \mathrm{C}$ in about $10 \mathrm{~min}$. To allow the precipitation to occur, the cell was held at $300^{\circ} \mathrm{C}$ for 24 hours. The cell was then cooled over about 10 min to room temperature. There were no visible carbon deposits on the cell or nickel mesh. XPS results did not show any carbon above baseline values. In addition, there was no $\mathrm{Ni}_{3} \mathrm{C}$ found. The analysis showed 61\% O, 18\% Ni, 15\% C, 5\% Zr, and 1\% Y (atomic \%). XPS analysis of 
the nickel mesh from this test showed $50 \% \mathrm{O}, 25 \% \mathrm{Ni}, 25 \% \mathrm{C}$ (atomic \%). The results are shown in Figure 4.19.

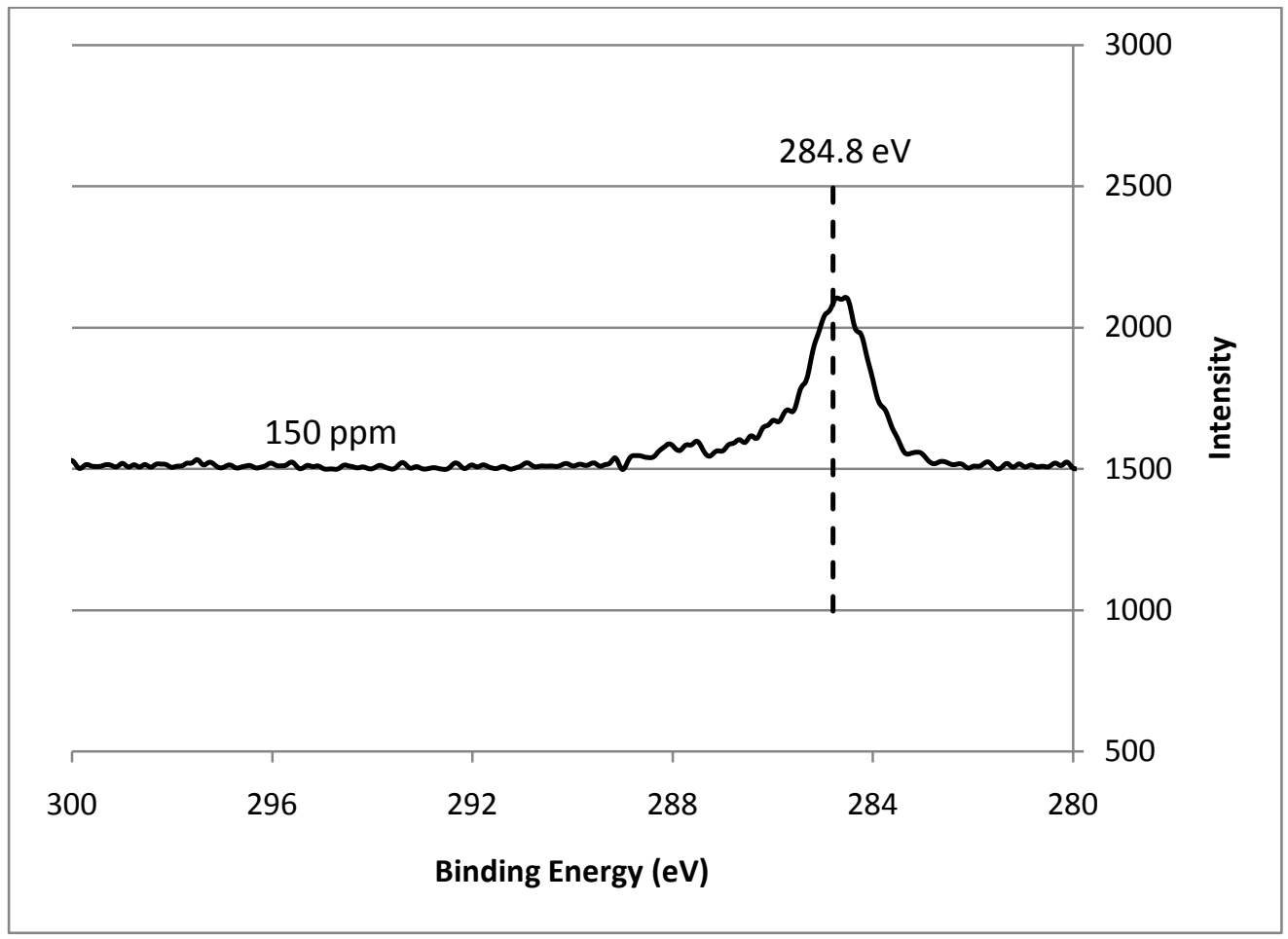

Figure 4.19 - XPS results of carbon for a button cell exposed to $150 \mathrm{ppm}$ benzene for $500 \mathrm{~h}$ at $800^{\circ} \mathrm{C}$. Graphitic carbon has a binding energy of $284.8 \mathrm{eV}$. The peak is not larger than the observed noise levels.

The button cell exposed to 100 ppm naphthalene was quenched under nitrogen to room temperature in 15 minutes and inspected after the $500 \mathrm{~h}$ test was completed. No visible evidence of carbon deposition was noted on the anode surface, the cell was intact, and no other notable signs of damage were recorded. XPS analysis of the cell surface showed some slight carbon deposits above noise levels, as seen in Figure 4.20. The values reported from XPS showed 51\% O, 35\% C, 7\% Zr, 6\% Ni, and 2\% Y (atomic \%), which does show carbon higher than the 14\% baseline concentration. The charge correction of $6.74 \mathrm{eV}$ is used in this test. This is used to compensate for charge that builds up on insulating samples. 


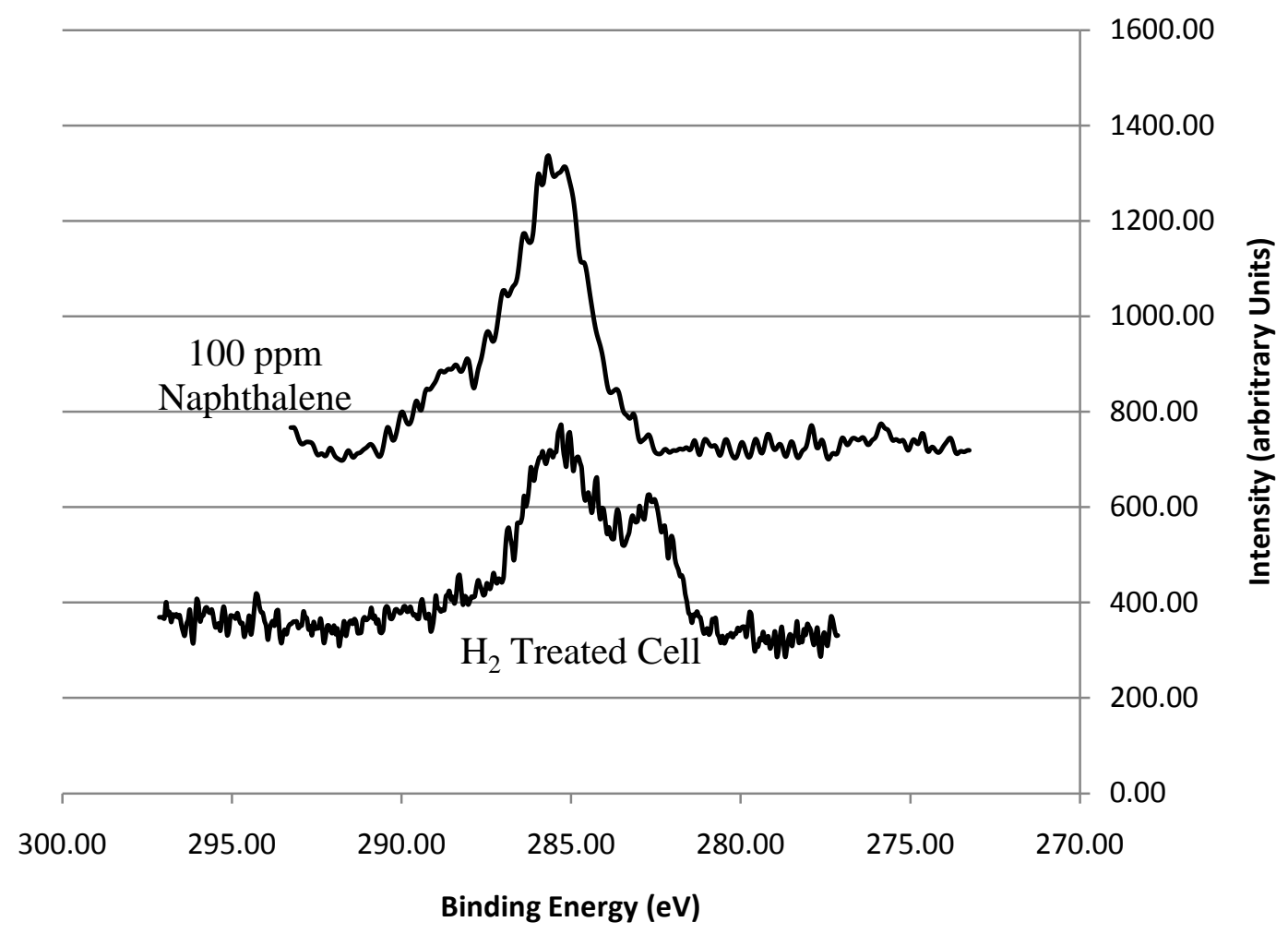

Figure 4.20 - XPS results of carbon for a button cell exposed to $100 \mathrm{ppm}$ naphthalene for $500 \mathrm{~h}$ at $800^{\circ} \mathrm{C}$. Hydrogen treated button cell is shown as a reference. Graphitic carbon has a binding energy of $284.8 \mathrm{eV}$. The peak is slightly larger than observed noise levels as shown in the curve for the hydrogen treated sample.

The peak at $282.5 \mathrm{eV}$ was not able to be determined.

The button cell exposed to 500 ppm naphthalene was quenched in nitrogen over 15 minutes and inspected after the $500 \mathrm{~h}$ test was completed. No visible evidence of carbon deposition was noted on the anode surface, the cell was intact and unmarred, and no other notable signs of damage were recorded. XPS analysis of the cell surface detected carbon deposits above the expected background and contamination levels. The carbon formed is likely associated with a nickel atom according to the XPS binding energy, as shown in Figure 4.21. The values reported from XPS showed 60\% O, 22\% C, 9\% Zr, 6\% Ni, and 2\% Y (atomic \%), which also shows carbon higher than the $14 \%$ baseline concentration. The charge correction of $3.15 \mathrm{eV}$ is used for this test. 


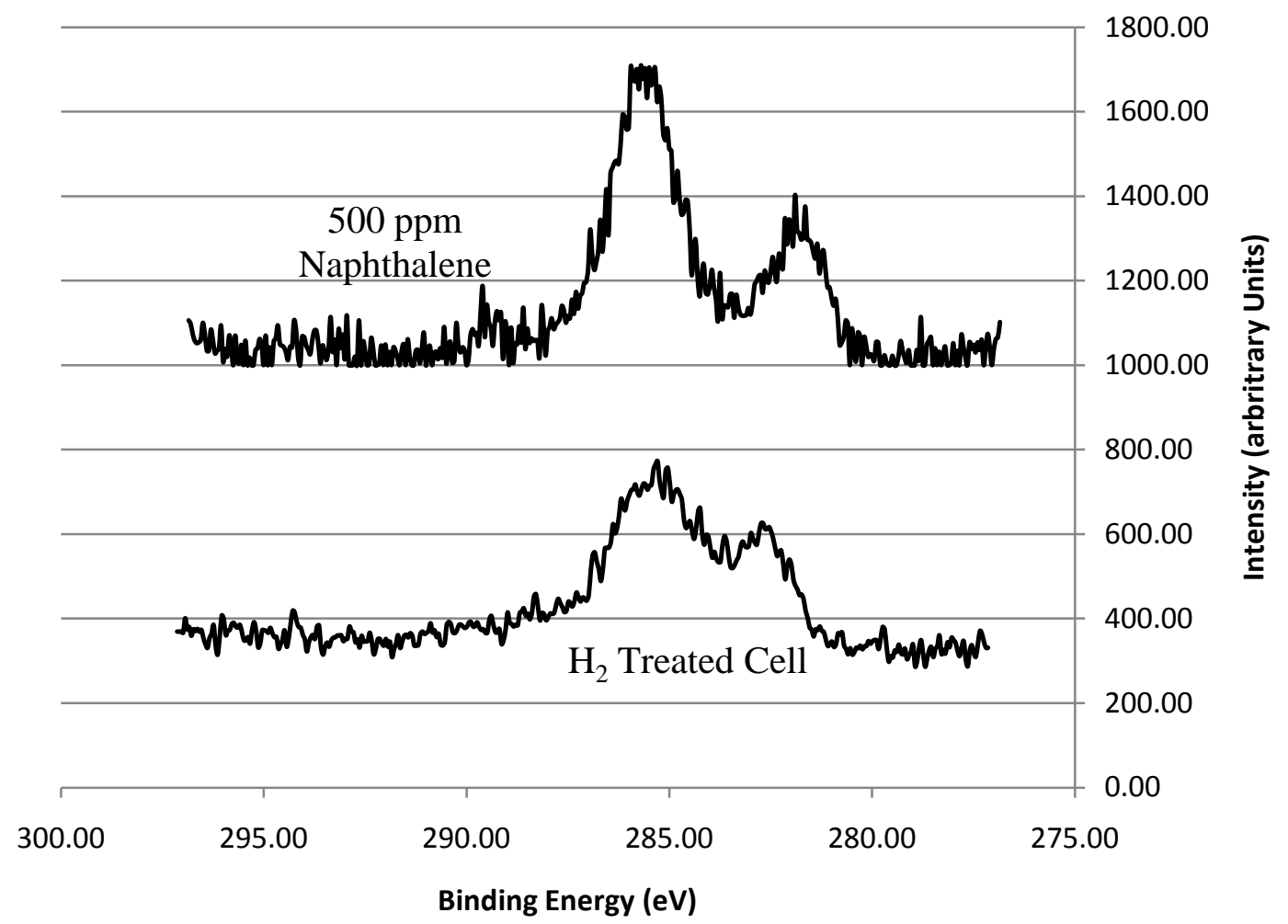

Figure 4.21 - XPS results of carbon for a button cell exposed to $500 \mathrm{ppm}$ naphthalene for $500 \mathrm{~h}$ at $800^{\circ} \mathrm{C}$. Hydrogen treated button cell is shown as a reference. Graphitic carbon has a binding energy of $284.8 \mathrm{eV}$. The peak is slightly larger than observed noise levels. The identity of the peak at $282.2 \mathrm{eV}$ likely corresponds to a nickel-carbide phase. 


\section{CHAPTER FIVE - DISCUSSION}

\subsection{Description of Degradation}

\subsubsection{Base Cell Degradation}

SOFCs degrade over their time of operation. The cause of this baseline performance loss is thermally induced degradation of the TPB. Elevated operation temperatures will cause movement of the elements composing the Ni-YSZ lattice, thereby decreasing the activity of the TPB. The characteristic time for this process scales with the flux of material diffusing out of the active region, which is dependent on Fick's Second Law of Diffusion. The diffusion of solids is a slow process because of the strong ionic bonding of yttrium and zirconium, and the size of the YSZ unit cell. The diffusion coefficient, $D$, is influenced by a temperature, $T$, and the diffusion activation energy $E_{D}$, which is a function of the interatomic coulombic forces of attraction. The relationship of the diffusion coefficient with temperature is given in Equation 5.1.

$$
D=D_{0} \exp \left(-\frac{E_{D}}{R T}\right)
$$

Thermochemical degradation is expected to commence when the fuel cell system departs from a stable equilibrium condition and continues until a new equilibrium has been established. When fuel cells are produced, they are sintered and equilibrated at temperatures above $1000^{\circ} \mathrm{C}$, which causes the structure to remain stable at lower temperatures. However, there is sufficient thermal energy available at $800^{\circ} \mathrm{C}$ to cause the solids to be mobile. Phase separation of materials within the anode is expected to occur, but the process will be slow due to the relative stability of the structure. The diffusion rate of the anode materials is predicted to be $\sim 10^{-14} \mathrm{~m} / \mathrm{s}$, based on the self-diffusion coefficient of nickel given as $1.4 \times 10^{-11} \mathrm{~m}^{2} / \mathrm{s}^{86}$. The crystallite size is expected to be about $10 \mathrm{~nm}\left(1 \times 10^{-8} \mathrm{~m}\right)^{40,87}$, therefore for an atom to diffuse out of the crystal structure 
requires $10^{6} \mathrm{~s}(\sim 280 \mathrm{~h})$. Phase separation likely requires movement of approximately $1 \times 10^{-7} \mathrm{~m}$, or about 28,000 h. A schematic diagram of the structure of YSZ is shown in Figure 5.1.

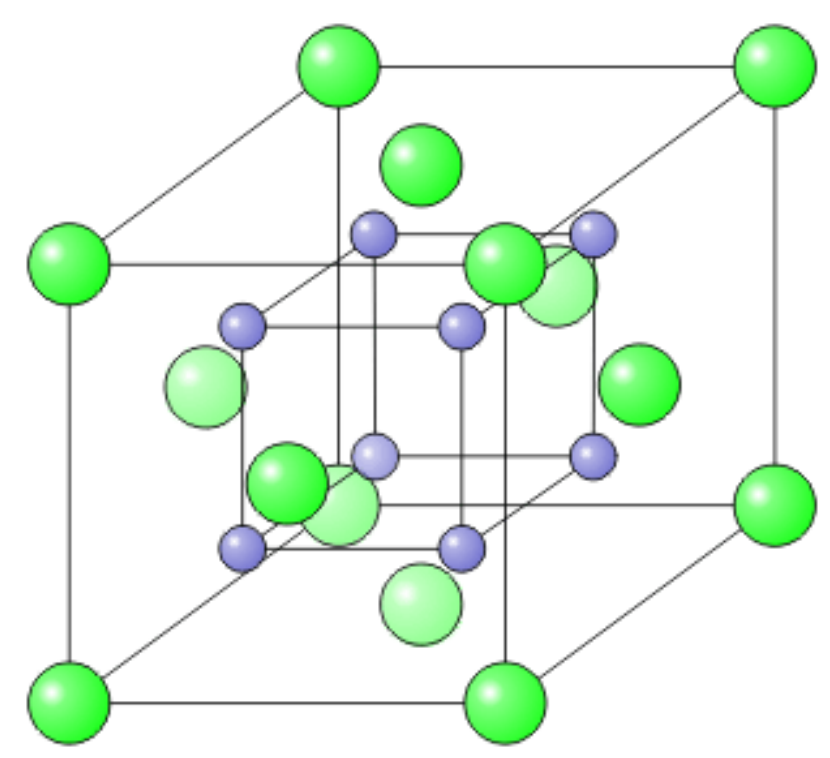

Figure 5.1 - YSZ Unit Cell Crystal Structure

Thermochemical degradation should appear as a linear decay during the $500 \mathrm{~h}$ duration of the conducted experiments. However, the solution (Equation 5.3) to Fick’s Second Law (Equation $5.2)$ is exponential, meaning that at long time $\left(\sim 10^{7} \mathrm{~h}\right)$, the baseline cell degradation will be an exponential decay function in time. This is demonstrated below:

$$
\begin{gathered}
\frac{\partial C}{\partial t}=D \frac{\partial^{2} C}{\partial x^{2}} \\
C(x, t)=\frac{s}{\sqrt{4 \pi D t}} \exp \left(\frac{-x^{2}}{4 D t}\right)
\end{gathered}
$$

Here, $S$ is the total amount of diffusing material, $C$ is the concentration, $x$ is the distance from the TPB, and $t$ is time.

Thermochemical degradation of the cell structure is a function of the methods, quality, and materials by which the SOFCs have been fabricated. Therefore, it is difficult to state a single 
base degradation rate that will be applicable to other fuel cells of the same type (even within production lots). The standard deviation of performance is currently unknown and unpublished. Previous guidelines have stated that $1 \%$ per $1000 \mathrm{~h}$ degradation rate is an acceptable goal for manufacturing. However, the button cells used in the experiments reported here have a syngas baseline operating potential of $0.800 \mathrm{~V}$ under a load of $0.25 \mathrm{~A} / \mathrm{cm}^{2}$ (the target current density at this voltage is between 0.25 and $0.50 \mathrm{~A} / \mathrm{cm}^{2}$ ). At the proposed degradation rate (assuming a linear degradation from $0.800 \mathrm{~V}$ ), the final predicted potential after $40,000 \mathrm{~h}$ of operation is $0.480 \mathrm{~V}$. It is not anticipated that SOFC applications will tolerate a potential this low, therefore achieving $1 \%$ per $1000 \mathrm{~h}$ degradation may not produce acceptable results. Baseline degradation rates of $0.50 \%$ and $0.25 \%$ per $1000 \mathrm{~h}$ result in a final potential of $0.640 \mathrm{~V}$ and $0.720 \mathrm{~V}$, respectively, after $40,000 \mathrm{~h}$ of operation. These degradation rate goals are more realistic for SOFCs operating with syngas fuel.

\subsubsection{Forward Attack Mechanisms}

A material can attack the anode of a SOFC by one of three primary classes of mechanisms. These mechanisms include the physical blocking of the fuel feed channels by filling of the pores

(Class I), surface adsorption which blocks the active TPB sites (Class II), and the formation of secondary nickel phases within the anode structure, including the formation of metal solutions (Class III). The TPB is the active reaction contact area where the catalytic electrode particles (Ni-YSZ), electrolyte, and fuel flow pores intersect as depicted in Figure 5.2. Each degradation class is discussed in detail in the following section as it relates to the performance of the TPB. 


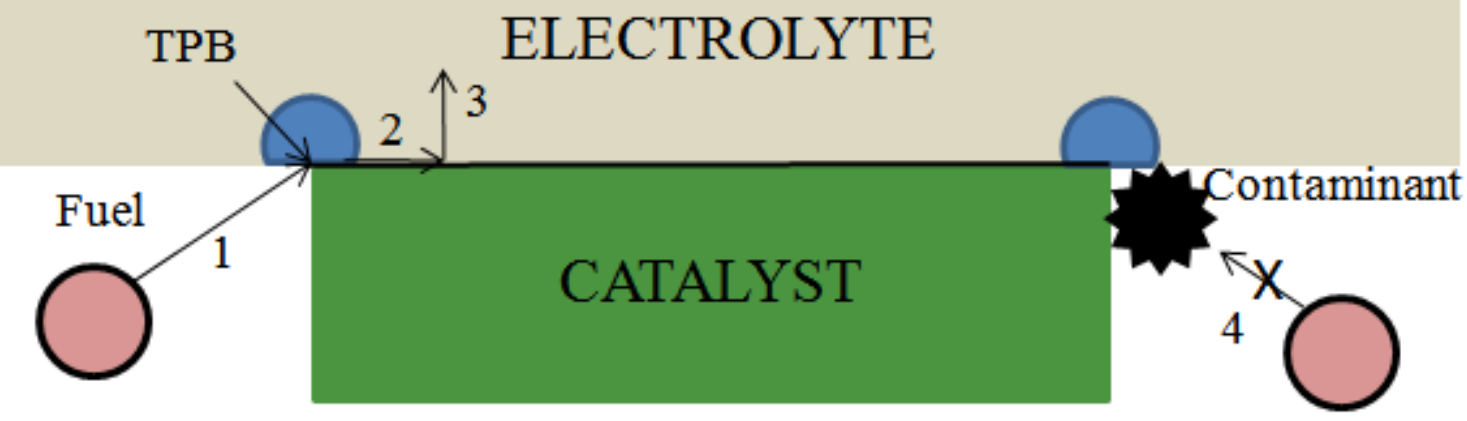

Figure 5.2 - Triple phase boundary illustration where fuel is incorporated into the electrolyte (1), fuel diffuses to the electrolyte/catalyst interface (2), and fuel reacts at catalyst surface (3). At (4), a contaminant is blocking the active TPB site, hindering reaction.

The Class I attack mechanism, the physical blocking of the fuel flow channels, is the simplest mechanism of attack. Contaminant molecules partially pass through the Ni-YSZ matrix, becoming lodged within the pores prior to reaching the TPB. The contaminant then agglomerates at a nucleation site and builds material that grows to the size of the pore. As these molecules build up, the amount of fuel reaching the TPB is effectively diminished due to the blocking of the flow channels for gas diffusion, starving the electrochemical reaction of fuel. It should also be noted that other particulates, including dust, could affect the cell performance in this manner. This results in a slow degradation of cell output until the supplied fuel is insufficient to supply a forward reaction at a rate required for a given current density. Because of the lack of reactant and the increase in polarization resistance, reversible reactions will begin to operate in the opposite direction. This allows excess oxygen to react with any molecule blocking fuel flow channels. Loading the cell under these conditions may cause delamination and failure of the cell. Lanthanum zirconate $\left(\mathrm{La}_{2} \mathrm{Zr}_{2} \mathrm{O}_{7}\right)$ will form in between the cathode and the electrolyte developing a mechanical stress that delaminates the cathode from the cell. Cell continuity is lost and no oxygen is transported for reaction. The characteristic time scale of an 
attack of this nature depends on the flow rate of the accumulating material. Sulfur, selenium, and chlorine are examples of contaminants that will degrade performance by this mechanism.

The Class II attack mechanism, surface adsorption on the active TPB sites, will also cause degradation in cell performance. The areas where the fuel, electrolyte, and catalyst meet are the areas where the electrochemical charge transfer reaction occurs. Fuel molecules diffuse through the pore structure of the Ni-YSZ anode and approach the TPB. The next step is subject to some debate in the literature. One possible mechanism is that the fuel diffuses into the electrolyte material, continuing along the electrolyte/catalyst interface until oxygen is available for electrochemical reaction. A second postulated mechanism states that the fuel molecules diffuse into the electrode material and react with oxygen ions that have diffused from the electrolyte into the YSZ. If the interface sites are blocked by contaminant, no fuel molecules reach the interface and no reaction takes place. This process is depicted in Figure 5.2. The characteristic time scale of this process is immediate upon introduction of the contaminant. Active TPB site adsorption will result in slowing the rate of the electrochemical reaction and an increase in polarization resistance. If the complete TPB surface area is occupied by non-reactive contaminant molecules, all electrochemical reaction will cease.

Class III attack mechanisms can be divided into two sub-classes, Class IIIA and Class IIIB. In Class IIIA degradation, the formation of secondary anodic metal (typically nickel) phases contributes to degradation of cell performance. At SOFC operating conditions, coal contaminants will react with nickel in the anode and form nickel-contaminant complexes. Some experimentally identified secondary nickel phases include: $\mathrm{Ni}_{3} \mathrm{P}, \mathrm{Ni}_{5} \mathrm{P}_{2}, \mathrm{NiS}$, and $\mathrm{Ni}_{5} \mathrm{As}_{2}$. These secondary phases alter the structure and physical properties of the nickel matrix, creating additional resistance to electron flow, lower gas diffusion, and a reduction in the TPB active 
area, all negatively affecting performance. The rate of Class IIIA degradation depends on the rate of the nickel/contaminant reaction.

For Class IIIB attack mechanisms, the formation of metal solutions is similar to secondary phase formation. Contaminant material will dissolve into the nickel matrix, forming a homogeneous solution that will behave differently than other secondary phase formations. Carbon will attack by this mechanism by dissolving into the nickel structure. This will result in the formation of poorly conducting $\mathrm{Ni}-\mathrm{C}$ metal solutions (such as $\mathrm{Ni}_{3} \mathrm{C}$ ) that resist electron flow. The relative time scale depends on the rate of dissolution of carbon into the nickel.

In some cases, species undergoing Class III attack mechanisms can precipitate out of solution to create Class II degradations. Carbon is a specific example of this. Carbon is only 2.7 atomic percent soluble (at $1326.5^{\circ} \mathrm{C}$ ) in nickel as shown in the binary phase diagram for $\mathrm{Ni}$ and $\mathrm{C}$ in Figure 5.3. As the temperature decreases, carbon solubility decreases. Consider a fuel cell operating at $800^{\circ} \mathrm{C}$ with carbon dissolved into the nickel anode. As the temperature is dropped to around $350^{\circ} \mathrm{C}$, where the carbide is stable, $\mathrm{Ni}_{3} \mathrm{C}$ will precipitate triggering Class II degradation. 


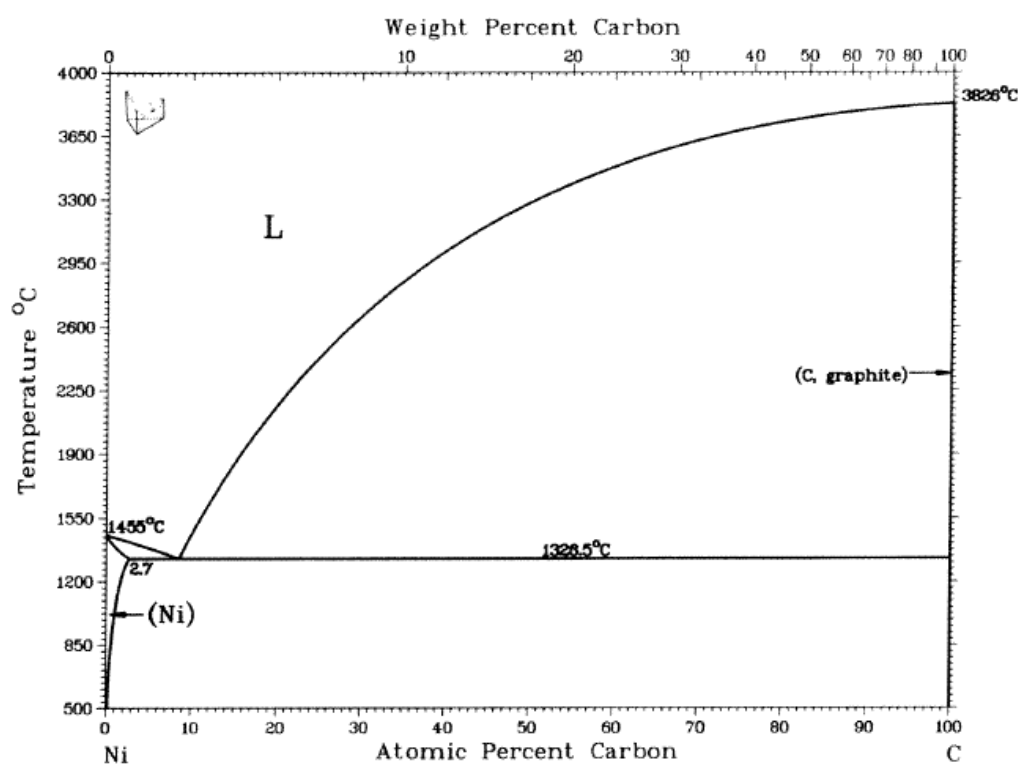

Figure 5.3 - Nickel-carbon phase diagram. ${ }^{88}$

Each mode of degradation has a characteristic degradation curve associated with it that can be used to identify the attack mechanism class from experimental data. The change in cell performance over time can be modeled as either an individual or a combination of degradation models. Instantaneous total degradation rates are postulated to be the sum of two or more individual physical processes. The indicated mechanism(s) physically describes the affect on cell performance. The identification of these characteristic curves is critical to identifying the mechanism of attack from each coal contaminant species. Once the mechanism of attack can be identified, a cleanup strategy can be formulated. Costly cleanup methods may be avoided entirely or utilized to a lesser extent if less expensive means of mitigation can be developed.

One primary model of observed degradation is depicted in Figure 5.4a. In this model, an immediate precipitous drop-off in performance is followed by a slower decay. Such behavior is indicative of Class II degradation. Class I and Class III degradation can also exhibit this 
behavior if equilibrium is rapidly reached. Chlorine, selenium, and low concentrations of sulfur demonstrate this effect.

A process in which an initial decay rate is slowed over time until a steady-state (thermochemical) degradation rate is reached is depicted in Figure 5.4b. This is the result of either a Class I or Class IIIB attack mechanism. In this case, the Class I mechanism will slowly fill the pores with contaminant material causing fuel availability at the TPB to decrease over time, even in the absence of surface adsorbed species. The Class IIIB attack mechanism will alter the electrochemical properties adding resistance to electron transport by changing the material itself. Carbon will dissolve into the nickel structure at elevated temperatures. If the operating temperature remains greater than $700^{\circ} \mathrm{C}$, the carbide that initially forms degrades into graphitic carbon. The altered structure of the nickel and the increasing amount of graphitic carbon within the structure will slowly increase resistance to electron movement. Once again, the solubility of carbon in nickel is low, allowing a supersaturated condition to be reached quickly.

Performance can decay at a slow (thermochemical) rate until a sudden and precipitous dropoff occurs. This is depicted in Figure 5.4c. Secondary phase formation is likely to result in this behavior, as the secondary phase is increasingly concentrated with contaminant until the chemical makeup is dramatically altered. In the case of Ni-S secondary phases, the melting point is lowered so that at normal SOFC operating temperatures, Ni-S will melt out of the anode. Phosphorus attack will also cause this behavior. Ni-P secondary phases are conductive, but they also permit enhanced Ni mobility. The anode is then stripped of Ni until only the YSZ skeleton remains, at which point electrochemical reaction ceases. Ni-P secondary phases are also extremely brittle and will fall apart as the concentration increases. 
Cell performance can also decay at an increasing rate over time. Class IIIA degradation will result in this kind of behavior as well. For example, Ni-As secondary phases accumulate at an increasing rate over time. The literature has shown that initial exposure of As (within 100 hours) will only allow As to adsorb on the nickel surface, which is instantaneous. At longer exposure periods, secondary Ni-As phases begin to form, even at low As concentrations. Thus, the kinetics support the fact that Ni-As secondary phase formation is slow. This degradation pattern is depicted in Figure 5.4d.
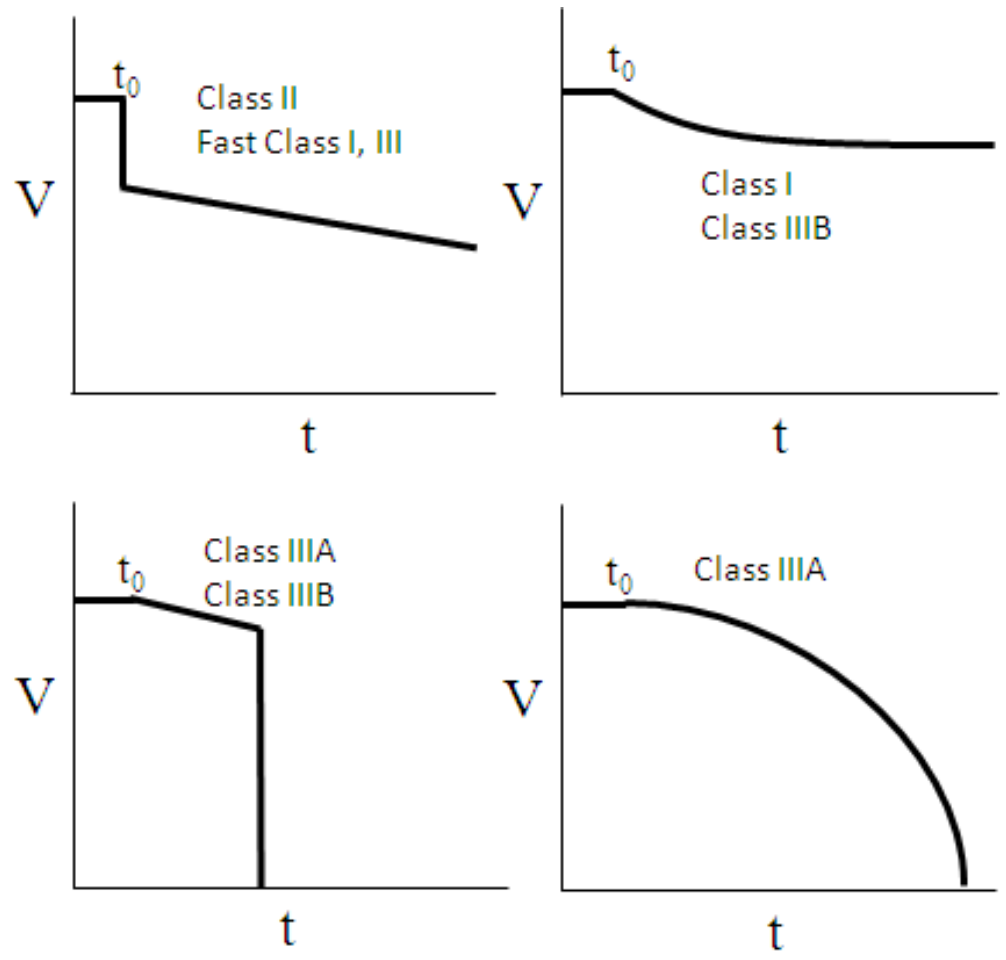

Figure 5.4 - Depiction of known cell performance degradation patterns when exposed to coal contaminants. Immediate precipitous dropout followed by slow decay (a - top left), fast initial decay followed by a slow, linear decay rate (b - top right), slow linear decay followed by sudden drop (c - bottom left), degradation increasing over time (d - bottom right).

\subsubsection{Degradation Reversibility}

Reverse electrochemical reactions warrant consideration and influence the mechanism by which the performance of SOFCs degrades, further complicating the analysis. The degradation 
processes can be reversed by forced electrochemical removal of adsorbed species from the surface or the removal of the bulk material by other reactants.

Class I degradations are reversible if only the pores are filled. The removal of contaminant from the bulk gas will likely cause the agglomerated material to be completely removed. In the case of coking, the steam present in the fuel stream will gasify the carbon to make $\mathrm{CO}$, and $\mathrm{H}_{2}$ or oxygen can react to produce $\mathrm{CO}_{2}$. Upon burnout of the contaminant, there will be no structural damage to the Ni-YSZ matrix. However, if material has penetrated into the grain boundaries, small spaces within the Ni-YSZ matrix will be occupied by contaminant material. Upon removal of material in this case, microstructural vacancies and defects will be present, causing structural fatigue.

Class II degradations are completely reversible. At low current densities, surface adsorbed species are more likely to remain in place. This is because the oxygen available for reaction is small considering that the fuel and the adsorbed species are in oxidative competition. When the current density is increased, there is additional oxygen available at TPB reaction sites, which will begin to oxidize surface adsorbed species. For example, surface adsorbed sulfur and carbon will oxidize to produce $\mathrm{SO}_{2}$ and $\mathrm{CO}_{2}$, respectively, which is then carried away through the exhaust stream. As another example, the literature has shown that chlorine and sulfur surface adsorption (when SOFCs are exposed to low concentrations of $\mathrm{S}$ and $\mathrm{Cl}$ ) is reversible when the flow of chlorine and sulfur is stopped.

Class IIIA degradations are partially reversible and the formation of secondary phases is a potentially reversible reaction. The removal of the contaminant species from the bulk gas or the addition of fuel species that will react with formed secondary phases is a method to reverse the secondary phase formation process. For example, when $\mathrm{Ni}_{3} \mathrm{P}$ and steam interact, as predicted by 
the thermodynamic software, FactSage, a small amount of $\left(\mathrm{P}_{2} \mathrm{O}_{3}\right)_{2}$ escapes in the gas phase, with all solid $\mathrm{Ni}_{3} \mathrm{P}$ converting to solid $\mathrm{Ni}$ and $\mathrm{Ni}_{5} \mathrm{P}_{2}$ at $800^{\circ} \mathrm{C}$. $\mathrm{Ni}_{5} \mathrm{P}_{2}$ will also form a small amount of $\left(\mathrm{P}_{2} \mathrm{O}_{3}\right)_{2}$, but the solid remains mostly $(95 \%)$ intact. $\mathrm{Ni}_{3} \mathrm{~S}_{2}$ decomposes a small amount $(<1 \%)$ in the presence of steam, forming a small amount of $\mathrm{SO}_{2}$ and $\mathrm{H}_{2} \mathrm{~S}$ in the gas phase.

Class IIIB degradations are possibly reversible if secondary phases have not been formed. Changing the operating conditions (either by cool-down or removal of contaminant from the bulk gas) will possibly cause the contaminant to precipitate out of solution. However, if a metal solution precipitates out, then the damage to the cell is not reversible. As mentioned, carbon is a good example of this behavior. Carbon likely dissolves into the nickel structure until an equilibrium state is reached at $800^{\circ} \mathrm{C}$. Upon cooling, literature has shown that $\mathrm{Ni}_{3} \mathrm{C}$ will precipitate out at temperatures near $350^{\circ} \mathrm{C}^{81}$. In this case, the nickel structure has been altered as nickel atoms are being precipitated out of the matrix in a Ni-C solution. The Ni-C phase diagram was shown previously in Figure 5.3.

\subsubsection{Sensitivity to Bulk Gas Concentration and Materials of Construction}

Sulfur offers an exemplary case to consider the effects of the bulk gas composition on the anode attack mechanism. At low concentrations (<100 ppm) and short exposure times, sulfur simply adsorbs onto the nickel surface, forming unstable nickel sulfides that block the access of $\mathrm{H}_{2}$ and $\mathrm{CO}$ to TPB reaction sites. At concentrations above $100 \mathrm{ppm}$, sulfur begins to form bulk nickel sulfides, which remain stable upon removal of the sulfur feed source (at constant current density). Carbon deposition is also affected by the composition of the bulk gas. The steam will either gasify any deposited carbon or shift any potential carbon depositing $\mathrm{CO}$ to $\mathrm{CO}_{2}$. 
Anode attack will also vary based on material of construction (MOC). A Ni-YSZ anode will behave differently than a Ni-GDC anode. Cathodes will behave differently based on MOC as well. Cathodes are typically made from LSM or LSCF.

\subsubsection{Compound Attack}

The previously discussed attack mechanisms take into consideration a single attack mechanism occurring at one time. It is likely that some contaminants, based on concentration and time of exposure could produce a curve as given in Figure 5.5. In this figure, the cell performance is experiencing an immediate performance drop from a Class II degradation mechanism, followed by a slow clogging of the pores or surface adsorption (Class I or Class II), and finally a terminal drop in voltage due to a Class III degradation.

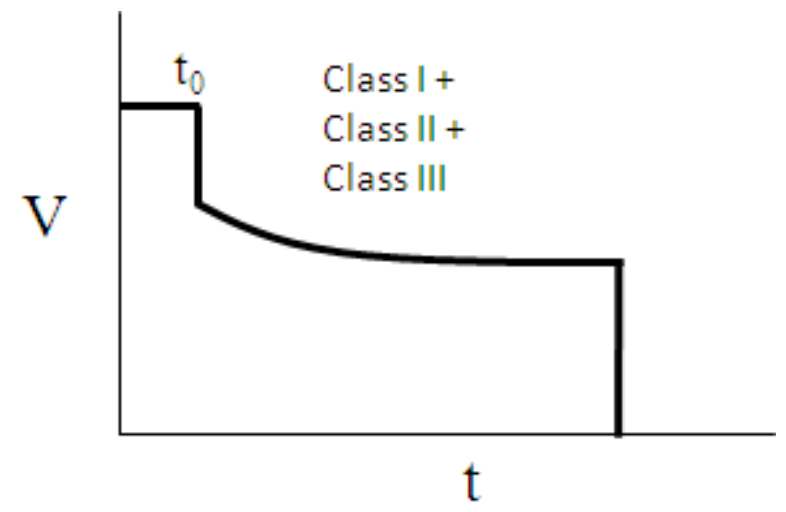

Figure 5.5 - Depiction of performance output for a cell undergoing a compound attack mechanism.

Arsenic poisoning is a good example of a contaminant that exhibits this behavior. Initially, arsenic blocks reactive TPB sites, causing a sudden drop in potential. As the contaminant slowly builds on the nickel surface, Ni-As secondary phases begin to form. Ni-As secondary phases 
cause the nickel atoms to become more mobile, forcing them to the surface until there is enough $\mathrm{Ni}$-As near the TPB to cease electrochemical reaction.

Compound attack will also occur when there is more than one contaminant in the fuel stream. With each contaminant degrading cell performance through its own mechanism of attack, multiple degradation patterns will be observed, including the sum of two or more degradation processes at any instantaneous point during the experiment. Numerous coal trace contaminants can adversely affect fuel cell performance. Phosphorus, arsenic, sulfur, and chlorine have been tested for their individual effects on fuel cell performance. Because each of these attack the functionality of the anode by different mechanisms, the inclusion of more than one contaminant will further complicate degradation.

There are also other materials that have been found not to degrade fuel cell performance by themselves, but will attack the anode when coupled with other contaminants. For example, alone, antimony does not affect performance and does not form secondary nickel phases. However, antimony does form $\mathrm{As}_{3} \mathrm{Sb}$ in the presence of arsenic, which in turn interacts with nickel to form NiSb. The effect of multiple contaminants on fuel cell performance has not been studied in detail, and few experiments have been conducted on SOFCs exposed to actual syngas from coal gasification.

\subsection{Application of Mechanisms to Observed Data}

\subsubsection{Overview of Analysis Methods}

Proposing a model for a degradation mechanism is very complex because of the size of the thermodynamic parameter space. Temperature, pressure, and each chemical species must be accounted for in order to develop a rigorous model. In the case of simulated syngas plus a single contaminant, the number of possible chemical species is between 10 and 20 when secondary 
phase formations, complexes, and individual fuel species are considered. One must carefully observe and use all of the available knowledge to formulate any postulations. Considering all of the possible mechanisms, the specific experimental results will be discussed for each of the species tested. The technique for data analysis which determines the acceptable contaminant concentrations is described in general, and then applied to each test case individually. Detailed descriptions of the features of each of the potential versus time plots are also given.

A majority of the test cells have a syngas baseline loaded potential of about $0.8 \mathrm{~V}$ under 0.25 $\mathrm{A} / \mathrm{cm}^{2}$. For the lifetime prediction of each cell, the starting potential is normalized to $0.800 \mathrm{~V}$. The range of the starting potential is $0.748-0.837 \mathrm{~V}$ and the average is $0.809 \mathrm{~V}$, verifying that this is a feasible normalization value. The final potential is determined for assumed baseline degradation rates of 1.0, 0.50, and $0.25 \%$ per $1000 \mathrm{~h}$ as discussed earlier in Section 5.1.1. The contaminant is expected to cause additional degradation simultaneous to these baseline rates and will depress the predicted potential at 40,000 h of operation. Lifetime predictions will use each of these three assumed baseline degradation rates to predict a contaminant concentration that allows the cell to perform at $0.6 \mathrm{~V}$ or $0.7 \mathrm{~V}$ at 40,000 hours of operation.

Using experimentally obtained potential changes over time, the performance can be modeled using one or a combination of mechanisms described in the previous sections. At an instantaneous point on the potential versus time curve, the deviation from the initial potential, $E_{0}$, is the result of one or more physical processes. Over each $500 \mathrm{~h}$ experiment, thermochemical degradation is not expected to reach equilibrium; therefore, it will cause a linear degradation over the entire experiment duration. The additional degradation is attributed to one or more quick processes, most likely surface adsorption of carbon or blockage of the bulk gas as it attempts to reach TPB reaction sites. Electrochemical processes will also be occurring when an 
external load is applied to the system. These include the reverse reactions discussed in Section 5.1.3. When occurring simultaneously, thermochemical and electrochemical processes may accelerate, decelerate, neutralize, or reverse the instantaneously observed total degradation, complicating the prediction process.

\subsubsection{Model Application to Experimental Data}

It is necessary to simplify the prediction by applying a single model or two consecutive predictive models to the observed data sets. It will be assumed that all of the aforementioned processes can be modeled in this way. Degradation will be modeled either as a continuous single model that occurs throughout the duration of the experiment (single-phase) or as a sequence of two consecutive processes (dual-phase). Each single-phase model will be used to represent one

or more simultaneous physical processes. Approximation of the individual decay processes is limited here to linear and exponential models. In general, it is found that application of a singlephase linear degradation model produces a conservative estimate of degradation (as a percentage of output loss per 1000 hours), but typically results in the poorest regressive fit. Single-phase exponential degradation produces a less conservative fit, as the prediction reaches a plateau value as time gets large, but has a superior regressive fit. More complex dual-phase models using both linear and exponential individual phases generally produce less conservative but more realistic degradation predictions. Final justification of the appropriateness of a given model requires firm identification of the physical processes associated with each phase.

Single-phase linear regression models are fitted using $E_{0}$ as the cell output during the syngas baseline and setting $t_{0}$ to correspond to the injection time of initial trace specie. GraphPad software is used to analyze the data sets for each contaminant exposure test. This software is able to determine and eliminate suspected outliers by the ROUT (robust regression and outlier 
removal) method In this method, the data are first fitted using a robust form of nonlinear regression, based on the assumption in which scatter follows a Lorentzian distribution. The method becomes more robust as it proceeds. Outliers are defined with an adjustable False Discovery Rate. Once the outliers are removed, the data are once again analyzed using ordinary least-squares regression ${ }^{89}$. The elimination of outliers results in curves with a higher coefficient of determination, $\mathrm{R}^{2}$ values. The software then plots model output with the smallest sum of squared error. The equation representing the fitted curve can be used to predict cell potential at $t$ $=40,000$ hours, giving a percent degradation per 1000 hours after division by 40 .

Single-phase exponential decay models are fitted similarly to linear decay models, and support the option of removing suspected outliers. The exponential decay model predicts a final plateau potential which is reached when $t=\infty$, and more accurately predicts the initial curvature of the cell output data. The single-phase exponential decay model may not accurately capture continuous thermochemical degradation occurring at long time, $t$, as experiment durations are limited to $500 \mathrm{~h}$.

A dual-phase mixed degradation model can be created that couples the measured initial exponential decay with projected long-term linear cell decay. This compound model is formed by applying the exponential decay model between the starting time, $t_{0}$, and the crossover time, $t_{c}$, and applying the linear decay model between $t_{c}$ and the final time, $t_{f}$. The crossover time is determined by assuming a linear cell degradation rate (1, 0.5 , or $0.25 \%$ per $1000 \mathrm{~h})$ and finding the time on the exponential decay curve at which the two rates are equivalent. A long-term linear cell degradation rate can be determined from experimental data or can be assumed to match a desired value. Different values of $t_{c}$ can be obtained based on the suspected baseline cell degradation rates mentioned previously. This method is demonstrated in Figure 5.6. 


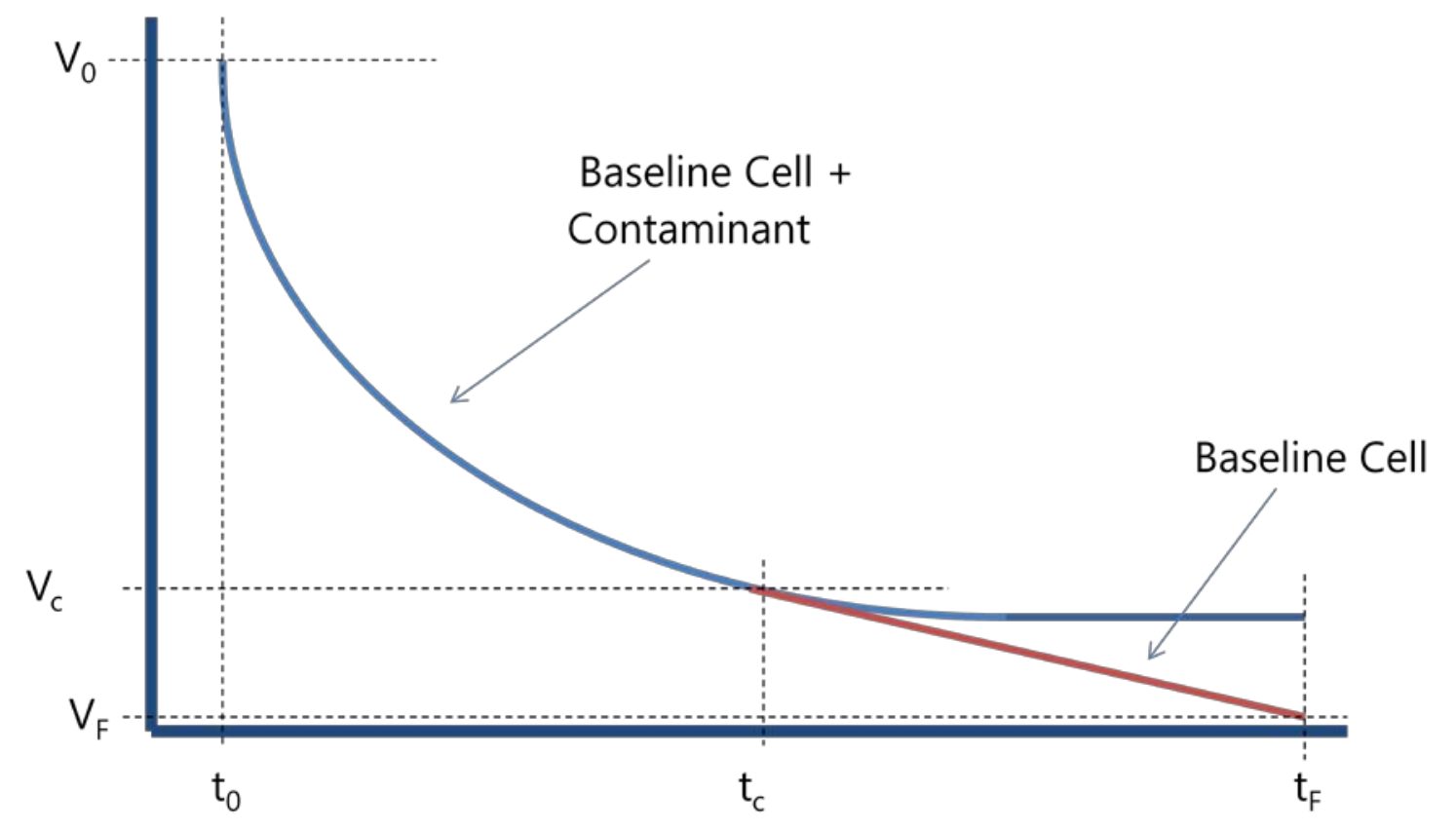

Figure 5.6 - Depiction of dual-phase degradation analysis method where $t_{c}$ is the time when the instantaneous degradation rate equals the assumed baseline degradation rate.

\subsubsection{Mercury}

As expected, data collected during mercury exposure at $1 \mathrm{ppm}$ and $10 \mathrm{ppm}$ are not remarkable with regard to accelerated degradation. Cell output remained steady throughout the $500 \mathrm{~h}$ testing period, no immediate potential change was observed upon introduction of mercury, and no precipitous decline in cell performance was recorded. Impedance data indicate that total resistance increases primarily in ohmic resistance, with insignificant increases in polarization resistance. Formation of stable solid Ni-Hg phases are not predicted using the thermodynamic equilibrium software FactSage, and no mercury is detected on the surface by XPS or other microscopy techniques.

Cell degradation rates for 1 ppm mercury exposure are given in Table 5.1 for two different degradation models, each considering the full data set and a set of data with outliers removed. The best fit is a single-phase exponential decay with outlier removal predicting a degradation of 
$0.017 \%$ per 1000 hours, with an $\mathrm{R}^{2}$ value of 0.4698 . The single-phase exponential decay with outliers included predicts the same degradation rate of $0.017 \%$ per 1000 hours but with an $\mathrm{R}^{2}$ value of 0.0928 . A single-phase linear decay model predicts a $0.81 \%$ per 1000 -hour degradation with an $\mathrm{R}^{2}$ of 0.0465 . When outliers are removed, the predicted degradation drops slightly to 0.79\% per 1000 hours, but the $\mathrm{R}^{2}$ improves to 0.2266 . Outlier removal for the 1 and $10 \mathrm{ppm}$ cases was about 1 and 5\% of the total data set, respectively, accounting for all excessive dropout and regions of OCV during impedance analysis.

For the case of the mercury tests, the reason for the poor $\mathrm{R}^{2}$ value is due to the combination of the slightly elevated noise level (due to water condensation) and the very small overall change in voltage ( $\sim 6 \mathrm{mV}$ at $40,000 \mathrm{~h})$. Therefore, a small change in noise level ( $1 \mathrm{mV}$ ) will cause the relative error to be large.

Table 5.1 - Summary of Results for 1 ppm Mercury Exposure

\begin{tabular}{|c|c|c|c|c|c|}
\hline Fit & $\begin{array}{c}\text { Initial } \\
\text { Potential } \\
{[\mathbf{V}]}\end{array}$ & $\begin{array}{c}\text { Potential } \\
\mathbf{G} \mathbf{t}= \\
\mathbf{4 0 , 0 0 0} \mathbf{~ h} \\
{[\mathbf{V}]}\end{array}$ & $\begin{array}{c}\text { Current } \\
\text { Density } \\
{\left[\mathbf{A} / \mathbf{c m}^{\mathbf{2}}\right]}\end{array}$ & $\begin{array}{c}\mathbf{\%} \text { Deg } \\
/ \mathbf{1 0 0 0} \\
\mathbf{h}\end{array}$ & $\mathbf{R}^{\mathbf{2}}$ \\
\hline Single-Phase Linear w/ Outliers & 0.832 & 0.562 & 0.250 & 0.809 & 0.0465 \\
\hline Single-Phase Linear w/o Outliers & 0.832 & 0.570 & 0.250 & 0.785 & 0.2266 \\
\hline Single-Phase Exp. w/ Outliers & 0.835 & 0.829 & 0.250 & 0.017 & 0.0928 \\
\hline Single-Phase Exp. w/o Outliers & 0.835 & 0.829 & 0.250 & 0.017 & 0.4698 \\
\hline Dual-Phase Decay w/ Outliers & 0.835 & 0.499 & 0.250 & 1.005 & N/A \\
\hline Dual-Phase Decay w/o Outliers & 0.835 & 0.499 & 0.250 & 1.005 & N/A \\
\hline
\end{tabular}

Cell degradation rates for $10 \mathrm{ppm}$ mercury exposure are given in Table 5.2 for two degradation models, each considering the full and truncated data sets. The best regressive fit is a single-phase exponential decay with outlier removal that predicts degradation of $0.04 \%$ per 1000 hours, with an $\mathrm{R}^{2}$ value of 0.8151 . The single-phase exponential decay model with outliers retained predicts a degradation of $0.03 \%$ per 1000 hours with an $\mathrm{R}^{2}$ value of 0.0352 . A single- 
phase linear decay model applied to the full data set predicts a 2.01\% per 1000-hour degradation with an $\mathrm{R}^{2}$ of 0.0319 . When outliers are removed, the degradation increases to $2.48 \%$ per 1000 hours, but the $\mathrm{R}^{2}$ improves significantly to 0.6473 . Outlier removal in either case was about 0.2 $0.3 \%$ of the total data set, accounting for all excessive dropout and regions of OCV during impedance analysis. Curves showing the single-phase linear and single-phase exponential fit for each mercury concentration are given in Figure 5.7.

The values for $\mathrm{R}^{2}$ in this case are slightly better because there is less noise due to water condensation. The small overall potential change in this case will also depress $\mathrm{R}^{2}$ values when there is noise present, but the data show less voltage dropout and potential for oscillation.

Table 5.2 - Summary of Results for 10 ppm Mercury Exposure

\begin{tabular}{|c|c|c|c|c|c|}
\hline Fit & $\begin{array}{c}\text { Initial } \\
\text { Potential } \\
\text { [V] }\end{array}$ & $\begin{array}{c}\text { Potential } \\
\mathbf{a} \mathbf{~ t =} \\
\mathbf{4 0 , 0 0 0} \mathbf{~ h} \\
{[\mathbf{V}]}\end{array}$ & $\begin{array}{c}\text { Current } \\
\text { Density } \\
{\left[\mathbf{A} / \mathbf{c m}^{\mathbf{2}}\right]}\end{array}$ & $\begin{array}{c}\mathbf{\%} \mathbf{\text { Deg }} \\
/ \mathbf{1 0 0 0} \\
\mathbf{h}\end{array}$ & $\mathbf{R}^{\mathbf{2}}$ \\
\hline Single-Phase Linear w/ Outliers & 0.812 & 0.159 & 0.250 & 2.01 & 0.0319 \\
\hline Single-Phase Linear w/o Outliers & 0.812 & 0.006 & 0.250 & 2.48 & 0.6473 \\
\hline Single-Phase Exp. w/ Outliers & 0.814 & 0.805 & 0.250 & 0.03 & 0.0352 \\
\hline Single-Phase Exp. w/o Outliers & 0.815 & 0.803 & 0.250 & 0.04 & 0.8151 \\
\hline Dual-Phase Decay w/ Outliers & 0.814 & 0.486 & 0.250 & 1.01 & N/A \\
\hline Dual-Phase Decay w/o Outliers & 0.815 & 0.485 & 0.250 & 1.01 & N/A \\
\hline
\end{tabular}




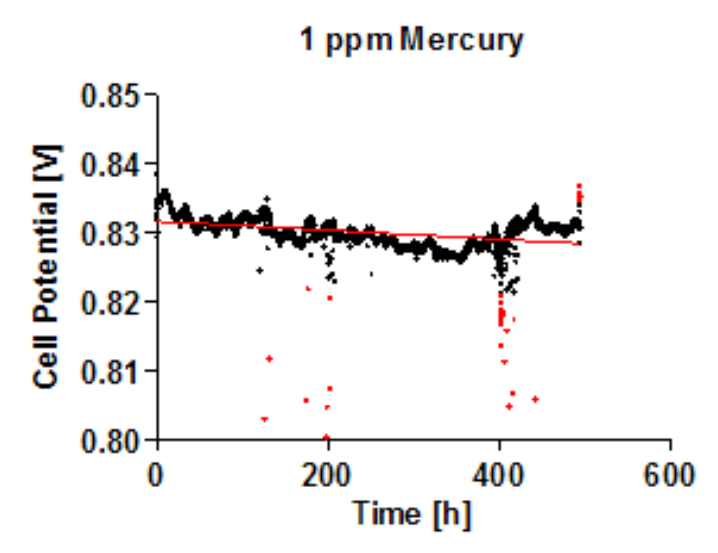

10 ppm Mercury

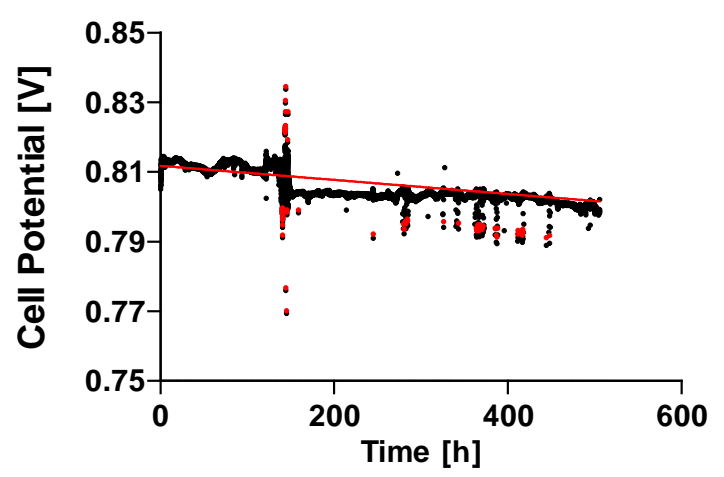

1 ppm Mercury

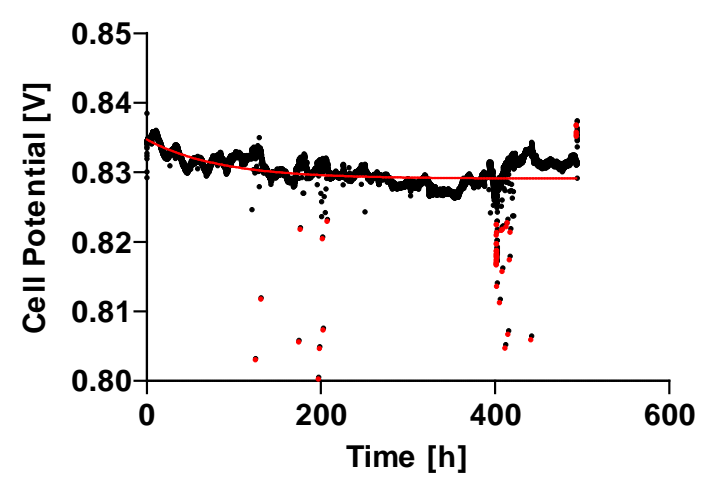

10 ppm Mercury

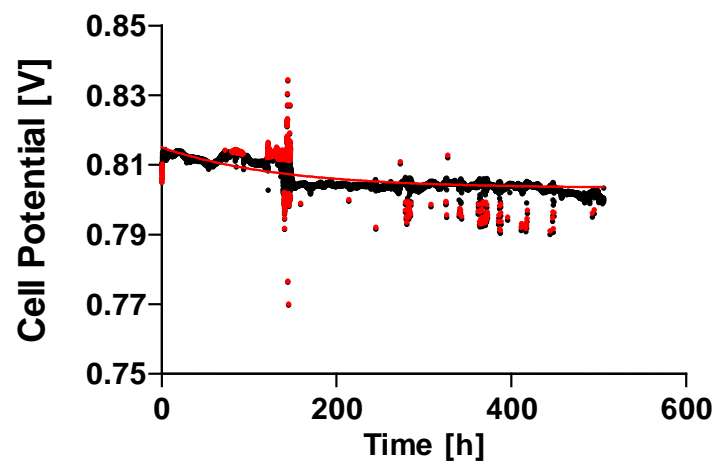

Figure 5.7 - Curves showing single-phase linear (left) and single-phase exponential (right) fits for 1 and 10 ppm mercury.

Although the rate of degradation was slightly greater for the $10 \mathrm{ppm}$ mercury case, the observed degradation is within a normal range of thermochemical degradation observed for the cells exposed to clean syngas. The impedance data demonstrating slightly increased ohmic resistance coupled with the lack of residual mercury in post-test analysis indicates that the mercury is not likely exerting a strong influence on cell performance. Furthermore, the exposure levels used in these tests are over 10 to 1000 times larger (on a ppm weight basis) than those expected from gasification of source coals containing the highest levels of mercury. Mercury exposure at concentrations as high as $10 \mathrm{ppm}$ is not predicted to accelerate degradation beyond that attributable to normal cell processes and, therefore, no additional cleanup procedures need to 
be considered for fuel cell operation. Cleanup is therefore limited to constraints dictated by environmental issues and not for fuel cell operation.

\subsubsection{Benzene}

Data collected for cell exposure to 15 and 150 ppm benzene show modest acceleration of degradation. Initial exposure of the cell to benzene is marked by a small increase in the output potential, approximately $12 \mathrm{mV}$. This phenomenon is discussed in more detail in Section 5.2.6.

Cell degradation rates for $15 \mathrm{ppm}$ benzene exposure are given in Table 5.3. The best fit observed is for the single-phase exponential decay model with outlier removal, which predicts a degradation of $0.05 \%$ per 1000 hours, and an $\mathrm{R}^{2}$ value of 0.9471 . The single-phase exponential decay model with outliers included predicts a degradation of $0.05 \%$ per 1000 hours with an $\mathrm{R}^{2}$ value of 0.0892 . A single-phase linear decay model fit to the entire data set results in a $2.64 \%$ per 1000 -hour degradation with an $\mathrm{R}^{2}$ of 0.0854 . When outliers are removed, the degradation increases slightly to $2.88 \%$ per 1000 hours, but $\mathrm{R}^{2}$ improves to 0.8817 . Outlier removal algorithms excluded $0.4-0.8 \%$ of the total data set, accounting for random dropouts and regions of OCV during impedance analysis. 
Table 5.3 - Summary of Results for 15 ppm Benzene Exposure

\begin{tabular}{|c|c|c|c|c|c|}
\hline Fit & $\begin{array}{c}\text { Initial } \\
\text { Potential } \\
\text { [V] }\end{array}$ & $\begin{array}{c}\text { Potential } \\
\mathbf{t =} \\
\mathbf{4 0 , 0 0 0} \\
{[\mathbf{V}]}\end{array}$ & $\begin{array}{c}\text { Current } \\
\text { Density } \\
{\left[\mathbf{A} / \mathbf{c m}^{2}\right]}\end{array}$ & $\begin{array}{c}\mathbf{\%} \text { Deg } \\
/ \mathbf{1 0 0 0} \\
\mathbf{h}\end{array}$ & $\mathbf{R}^{\mathbf{2}}$ \\
\hline Single-Phase Linear w/ Outliers & 0.834 & 0.000 & 0.250 & 2.64 & .0854 \\
\hline Single-Phase Linear w/o Outliers & 0.834 & 0.000 & 0.250 & 2.88 & .8817 \\
\hline Single-Phase Exp. w/ Outliers & 0.835 & 0.802 & 0.250 & 0.05 & .0892 \\
\hline Single-Phase Exp. w/o Outliers & 0.837 & 0.821 & 0.250 & 0.05 & .9471 \\
\hline Dual-Phase Decay w/ Outliers & 0.835 & 0.498 & 0.250 & 1.01 & N/A \\
\hline Dual-Phase Decay w/o Outliers & 0.837 & 0.498 & 0.250 & 1.01 & N/A \\
\hline
\end{tabular}

Cell degradation rates for $150 \mathrm{ppm}$ benzene exposure are given in Table 5.4. The best fit observed is for the single-phase exponential decay model with outliers removed, which predicts degradation of $0.05 \%$ per 1000 hours, with an $\mathrm{R}^{2}$ value of 0.9315 . The single-phase exponential decay with outliers included predicts a degradation of $0.05 \%$ per 1000 hours with an $\mathrm{R}^{2}$ value of 0.9057. A single-phase linear decay model including the entire data set results in a $2.74 \%$ per 1000-hour degradation with an $\mathrm{R}^{2}$ of 0.8755 . When outliers are removed, the degradation prediction slightly decreases to $2.72 \%$ per 1000 hours, but the $\mathrm{R}^{2}$ improves to 0.9047 . It should be noted that the linear fit $\mathrm{R}^{2}$ values in this case are higher than for other cases because the OCV data points were removed prior to analysis in order to get the results to converge. Outlier removal was about $0.6-0.8 \%$ of the total data set, accounting for random short duration dropouts and regions of OCV during impedance analysis. Curves showing the single-phase linear and single-phase exponential fit for each benzene concentration are given in Figure 5.8. 
Table 5.4 - Summary of Results for 150 ppm Benzene Exposure

\begin{tabular}{|c|c|c|c|c|c|}
\hline Fit & $\begin{array}{c}\text { Initial } \\
\text { Potential } \\
\text { [V] }\end{array}$ & $\begin{array}{c}\text { Potential } \\
\mathbf{t =} \\
\mathbf{4 0 , 0 0 0} \mathbf{h} \\
{[\mathbf{V}]}\end{array}$ & $\begin{array}{c}\text { Current } \\
\text { Density } \\
{\left[\mathbf{A} / \mathbf{c m}^{2}\right]}\end{array}$ & $\begin{array}{c}\mathbf{\%} \text { Deg } \\
/ \mathbf{1 0 0 0} \\
\mathbf{h}\end{array}$ & $\mathbf{R}^{\mathbf{2}}$ \\
\hline Single-Phase Linear w/ Outliers & 0.836 & 0.000 & 0.250 & 2.74 & .8755 \\
\hline Single-Phase Linear w/o Outliers & 0.836 & 0.000 & 0.250 & 2.72 & .9047 \\
\hline Single-Phase Exp. w/ Outliers & 0.836 & 0.821 & 0.250 & 0.05 & .9057 \\
\hline Single-Phase Exp. w/o Outliers & 0.836 & 0.820 & 0.250 & 0.05 & .9315 \\
\hline Dual-Phase Decay w/ Outliers & 0.836 & 0.499 & 0.250 & 1.01 & N/A \\
\hline Dual-Phase Decay w/o Outliers & 0.836 & 0.500 & 0.250 & 1.01 & N/A \\
\hline
\end{tabular}

15 ppm Benzene

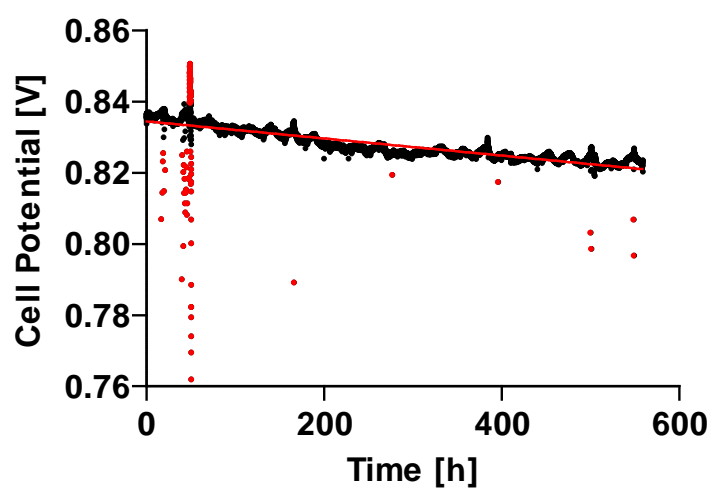

150 ppm Benzene

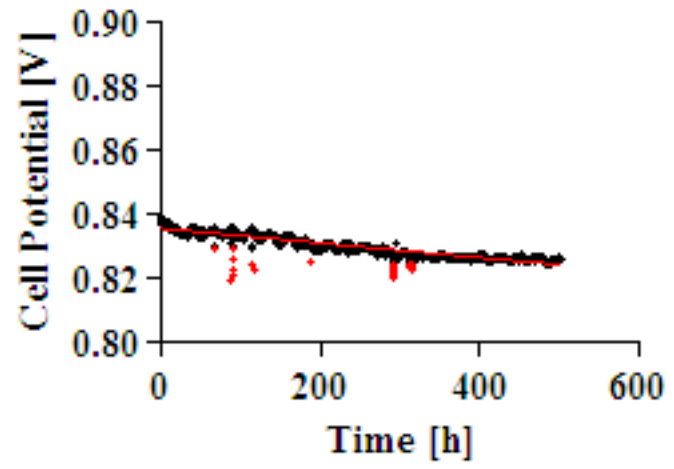

15 ppm Benzene

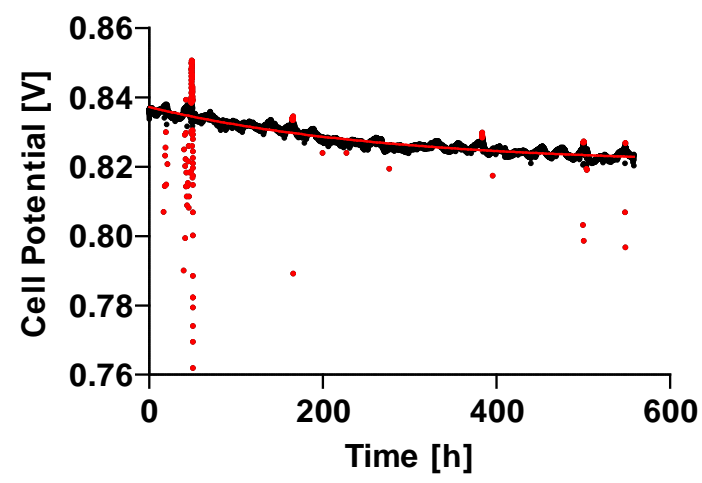

$150 \mathrm{ppm}$ Benzene

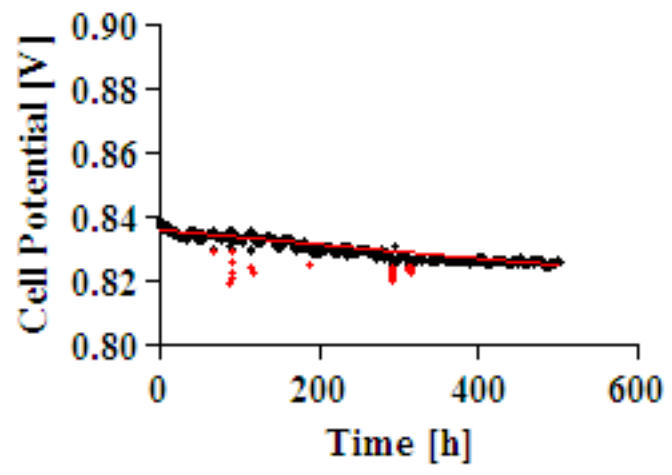

Figure 5.8 - Curves showing single-phase linear (left) and single-phase exponential (right) fits for 15 and 150 ppm benzene. 
Cell lifetime predictions for exposure to benzene can be generated by applying the dualphase mixed model, applying a normalized starting cell potential of $0.800 \mathrm{~V}$, a desired final cell potential, and assumed thermal degradation rate. Unfortunately, the degradation rates for the 15 and $150 \mathrm{ppm}$ cases are too similar to accurately extrapolate to long-term performance values. At 1.0\% per 1000 hours baseline cell degradation, no concentration of benzene allows a final potential of $0.6 \mathrm{~V}$ at $40,000 \mathrm{~h}$. At 0.50 and $0.25 \%$, the similarity of the degradation rates dictates that benzene in the fuel stream must be cleaned to values of less than $150 \mathrm{ppm}$, with no exact value confidently quoted. The cell will perform at a potential of $0.6 \mathrm{~V}$ at 40,000 h with $150 \mathrm{ppm}$ benzene or less, and some lesser value will allow the cell to operate at $0.7 \mathrm{~V}$. Figure 5.9 is provided to show the qualitative relationship for concentrations of benzene between 0 and 150 ppm, and is not considered a quantitative representation.
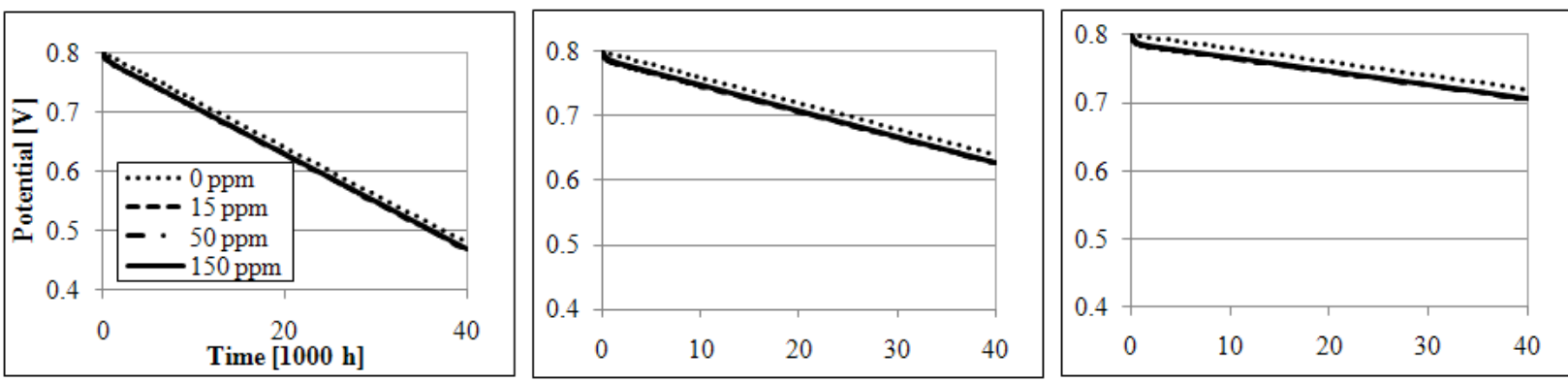

Figure 5.9 - Predicted potential for a cell lifetime of $40,000 \mathrm{~h}$ based on benzene concentration and assumed baseline cell degradation rates of a) $1.0 \%$ per $\mathrm{kh}$ b) $0.50 \%$ per kh c) $0.25 \%$ per kh.

\subsubsection{Naphthalene}

Data collected for cell exposure to 100 and 500 ppm naphthalene show modest acceleration of degradation. Initial exposure of the cell to naphthalene is marked by a small increase in the output potential, about $10 \mathrm{mV}$. Accelerated, non-linear degradation is clearly observed in the first few hundred hours of operation, but slows as the exposure period progresses. Impedance data indicate increases in polarization resistance, which slow after the first few hundred hours. 
Cell degradation rates for 100 ppm naphthalene exposure are given in Table 5.5. The best fit observed is for the single-phase exponential decay model with outlier removal, which predicts a degradation of $0.06 \%$ per 1000 hours, and an $\mathrm{R}^{2}$ value of 0.8603 . The single-phase exponential decay model with outliers included predicts a degradation of $0.06 \%$ per 1000 hours with an $\mathrm{R}^{2}$ value of 0.2469 . A single-phase linear decay model fit to the entire data set results in a $4.19 \%$ per 1000-hour degradation with an $\mathrm{R}^{2}$ of 0.2150 . When outliers are removed, the degradation increases to $4.39 \%$ per 1000 hours, and the $\mathrm{R}^{2}$ improves to 0.7227 . Outlier removal algorithms excluded $1-3 \%$ of the total data set, accounting for random dropouts and regions of OCV during impedance analysis.

Table 5.5 - Summary of Results for 100 ppm Naphthalene Exposure

\begin{tabular}{|c|c|c|c|c|c|}
\hline Fit & $\begin{array}{c}\text { Initial } \\
\text { Potential } \\
\text { [V] }\end{array}$ & $\begin{array}{c}\text { Potential } \\
\mathbf{t =} \\
\mathbf{4 0 , 0 0 0} \mathbf{h} \\
{[\mathbf{V}]}\end{array}$ & $\begin{array}{c}\text { Current } \\
\text { Density } \\
{\left[\mathbf{A} / \mathbf{c m}^{\mathbf{2}}\right]}\end{array}$ & $\begin{array}{c}\mathbf{\%} \text { Deg } \\
\text { / 1000 } \\
\mathbf{h}\end{array}$ & $\mathbf{R}^{\mathbf{2}}$ \\
\hline Single-Phase Linear w/ Outliers & 0.743 & 0.000 & 0.250 & 4.19 & .2150 \\
\hline Single-Phase Linear w/o Outliers & 0.743 & 0.000 & 0.250 & 4.39 & .7227 \\
\hline Single-Phase Exp. w/ Outliers & 0.748 & 0.730 & 0.250 & 0.06 & .2469 \\
\hline Single-Phase Exp. w/o Outliers & 0.748 & 0.730 & 0.250 & 0.06 & .8603 \\
\hline Dual-Phase Decay w/ Outliers & 0.748 & 0.442 & 0.250 & 1.02 & N/A \\
\hline Dual-Phase Decay w/o Outliers & 0.748 & 0.442 & 0.250 & 1.02 & N/A \\
\hline
\end{tabular}

Cell degradation rates for 500 ppm naphthalene exposure are given in Table 5.6. The best fit observed is for the single-phase exponential decay model with outliers removed, which predicts degradation of $0.18 \%$ per 1000 hours, with an $\mathrm{R}^{2}$ value of 0.9832 . The single-phase exponential decay with outliers included predicts a degradation of $0.17 \%$ per 1000 hours with an $\mathrm{R}^{2}$ value of 0.7233. A single-phase linear decay model including the entire data set results in an $11.4 \%$ per 1000-hour degradation with an $\mathrm{R}^{2}$ of 0.6370 . When outliers are removed, the degradation prediction decreases to $7.7 \%$ per 1000 hours, and the $\mathrm{R}^{2}$ improves to 0.8599 . Outlier removal was about $1-3 \%$ of the total data set, accounting for random short duration dropouts and regions 
of OCV during impedance analysis. Curves showing the single-phase linear and single-phase exponential fit for each benzene concentration are given in Figure 5.10.

Table 5.6 - Summary of Results for 500 ppm Naphthalene Exposure

\begin{tabular}{|c|c|c|c|c|c|}
\hline Fit & $\begin{array}{c}\text { Initial } \\
\text { Potentia } \\
\text { I [V] }\end{array}$ & $\begin{array}{c}\text { Potentia } \\
1 @ \mathrm{t}= \\
40,000 \mathrm{~h} \\
\text { [V] }\end{array}$ & $\begin{array}{l}\text { Current } \\
\text { Density } \\
{\left[\mathrm{A} / \mathbf{c m}^{2}\right]}\end{array}$ & $\begin{array}{c}\text { \% Deg } \\
/ 1000 \\
\text { h }\end{array}$ & $\mathbf{R}^{2}$ \\
\hline Single-Phase Linear w/ Outliers & 0.765 & 0.000 & 0.250 & 11.36 & .6370 \\
\hline Single-Phase Linear w/o Outliers & 0.765 & 0.000 & 0.250 & 7.73 & .8599 \\
\hline Single-Phase Exp. w/ Outliers & 0.778 & 0.726 & 0.250 & 0.17 & .7233 \\
\hline Single-Phase Exp. w/o Outliers & 0.782 & 0.727 & 0.250 & 0.18 & .9832 \\
\hline Dual-Phase Decay w/ Outliers & 0.778 & 0.441 & 0.250 & 1.08 & $\mathrm{~N} / \mathrm{A}$ \\
\hline Dual-Phase Decay w/o Outliers & 0.782 & 0.441 & 0.250 & 1.09 & N/A \\
\hline
\end{tabular}

100 ppm Naphthalene

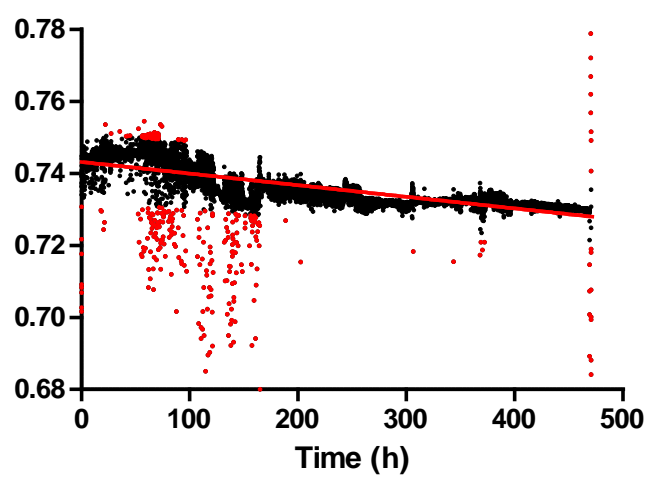

500 ppm Naphthalene

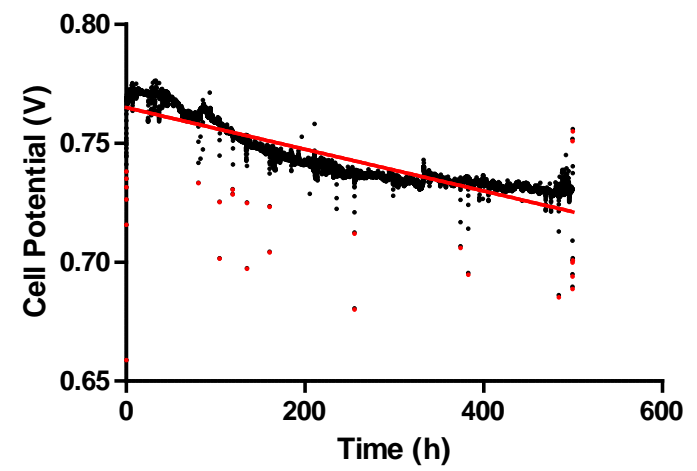

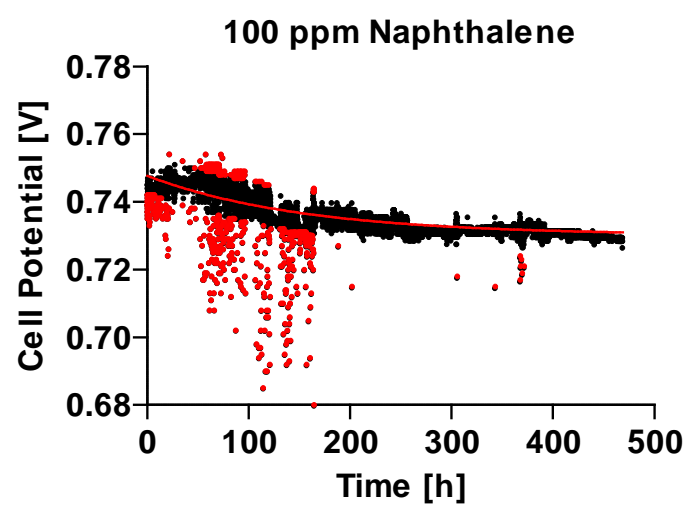

500 ppm Naphthale ne

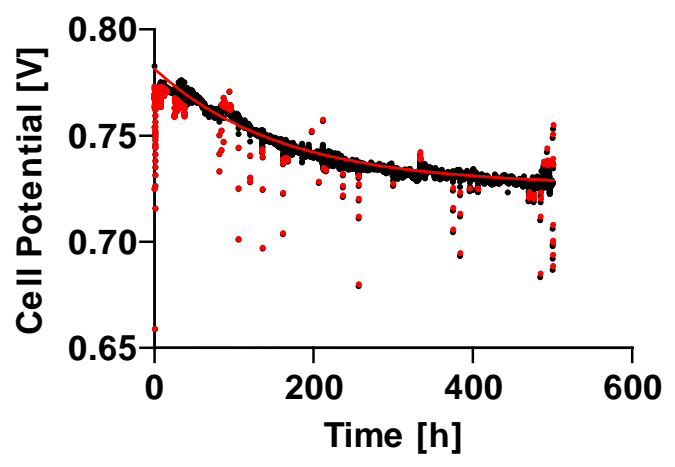

Figure 5.10 - Curves showing single-phase linear and single-phase exponential fits for 100 and 500 ppm naphthalene. 
Cell lifetime predictions for exposure to naphthalene can be generated by applying the dualphase mixed model and assuming a starting cell potential, a desired final cell potential, and an assumed thermal degradation rate. Figure 5.11 depicts the cell potential over time for naphthalene exposure between $0 \mathrm{ppm}$ and $1000 \mathrm{ppm}$ for assumed base cell degradation rates of 1, 0.5, and $0.25 \% / 1000$ hours. Using an assumed base cell degradation rate of $0.5 \%$ / 1000 hours, and acceptable final potential of $0.6 \mathrm{~V}$, and a 40,000 h desired lifetime, the naphthalene continuous exposure limit of the cell is $360 \mathrm{ppm}$. Using an assumed base cell degradation rate of $0.25 \%$ / 1000 hours, and acceptable final potential of $0.6 \mathrm{~V}$, and a 40,000 $\mathrm{h}$ desired lifetime, the naphthalene continuous exposure limit of the cell is $1200 \mathrm{ppm}$. At this baseline degradation rate, the cell will continue to operate at a potential of $0.7 \mathrm{~V}$ when exposed to $110 \mathrm{ppm}$ naphthalene.
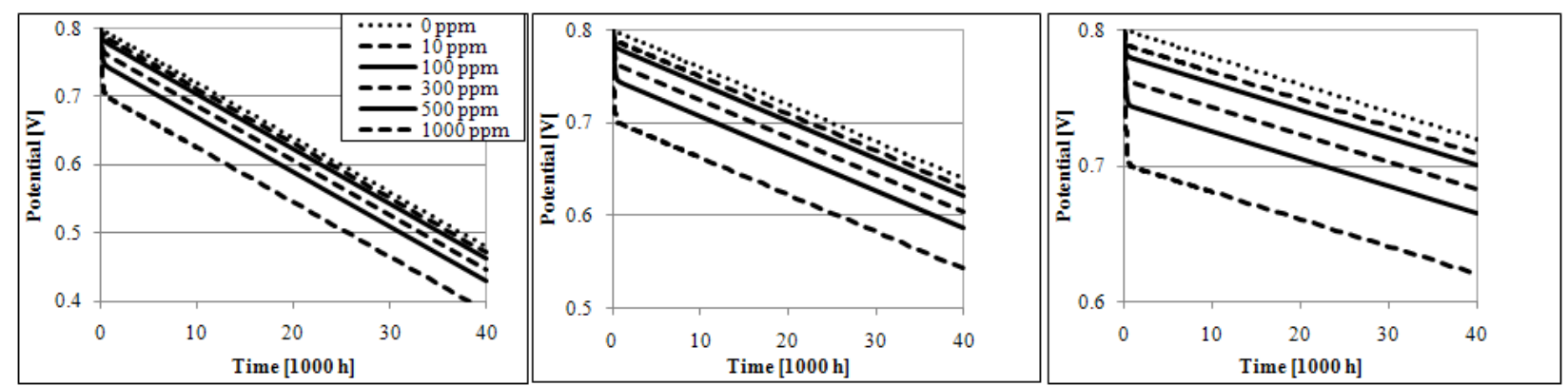

Figure 5.11 - Predicted potential for a cell lifetime of $40,000 \mathrm{~h}$ based on naphthalene concentration and assumed baseline cell degradation rates of a) $1.0 \%$ per $\mathrm{kh} b$ ) $0.50 \%$ per $\mathrm{kh}$ c) $0.25 \%$ per $\mathrm{kh}$. Please note that the exponential decay model only operates for a short time compared to the thermal decay.

\subsubsection{Cell Output Improvement upon Addition of Hydrocarbon Fuel}

The potential output is observed to increase instantly upon addition of hydrocarbon material to the fuel stream, consistent with observations by Mermelstein et al. ${ }^{74}$. The behavior is attributed exclusively to the presence of the hydrocarbons, as this phenomenon was not observed when the contaminant delivery system is engaged with mercury contaminant or noncontaminated syngas streams. 
Although SOFC are able to internally reform hydrocarbons, the sudden increase in potential is explicable when considering carbon reaction processes alternative to traditional water-gas shift and methane-steam reforming reactions.

Current densities larger than the electrochemical hydrogen oxidation rate will allow oxygen to be available to partially oxidize hydrocarbon species. Benzene is directly oxidized as shown in Equation 5.6.

$$
\mathrm{C}_{6} \mathrm{H}_{6}+7.5 \mathrm{O}_{2} \Leftrightarrow 6 \mathrm{CO}_{2}+3 \mathrm{H}_{2} \mathrm{O} \quad \mathrm{E}_{800}^{\circ}=1.16 \mathrm{~V}
$$

Note that the calculated Nernst potential for Reaction 5.6 exceeds the humidified hydrogen $\left(97 \%-\mathrm{H}_{2} / 3 \%-\mathrm{H}_{2} \mathrm{O}\right)$ potential by $60 \mathrm{mV}$ and the calculated syngas potential by $182 \mathrm{mV}$. The Nernst potential at $800^{\circ} \mathrm{C}$ for benzene is greater than that for hydrogen or syngas. The benzene reforming reaction is given in Equation 5.7.

$$
\mathrm{C}_{6} \mathrm{H}_{6}+6 \mathrm{H}_{2} \mathrm{O} \Leftrightarrow 6 \mathrm{CO}+9 \mathrm{H}_{2} \quad \mathrm{E}_{800}^{\circ}=0.99 \mathrm{~V}
$$

Naphthalene is directly oxidized as shown in Equation 5.8.

$$
\mathrm{C}_{10} \mathrm{H}_{8}+12 \mathrm{O}_{2} \Leftrightarrow 10 \mathrm{CO}_{2}+4 \mathrm{H}_{2} \mathrm{O} \quad \mathrm{E}_{800}^{\circ}=1.11 \mathrm{~V}
$$

Note that the calculated Nernst potential for Reaction 5.8 exceeds the humidified hydrogen $\left(97 \%-\mathrm{H}_{2} / 3 \%-\mathrm{H}_{2} \mathrm{O}\right)$ potential by $10 \mathrm{mV}$ and the calculated syngas potential by $132 \mathrm{mV}$. The naphthalene reforming reaction is given in Equation 5.9.

$$
\mathrm{C}_{10} \mathrm{H}_{8}+10 \mathrm{H}_{2} \mathrm{O} \Leftrightarrow 10 \mathrm{CO}+14 \mathrm{H}_{2} \quad \mathrm{E}_{800}^{\circ}=0.64 \mathrm{~V}
$$


Solid-state reactions with absorbed carbon (Ni-C solutions), crystalline carbon $\left(\mathrm{Ni}_{3} \mathrm{C}\right.$, graphite), and surface adsorbed carbon could create a direct carbon fuel cell. Direct oxidation of adsorbed surface carbon and Nernst potential at the cell operating temperature are shown in Equation 5.10.

$$
\mathrm{C}+\mathrm{O}_{2} \Leftrightarrow \mathrm{CO}_{2} \quad \mathrm{E}_{800}^{\circ}=1.04 \mathrm{~V}
$$

Surface carbon arises from deposition through the Boudouard reaction or from phase separation of excess carbon dissolved in the Ni-C system. The carbon solubility in a binary system of Ni-C is less than $0.1 \%$ (by weight) at $800^{\circ} \mathrm{C}$, with additional carbon separating to form graphite. Crystalline $\mathrm{Ni}_{3} \mathrm{C}$ is metastable and not expected to be present at temperatures above $400^{\circ} \mathrm{C}{ }^{90}$, as the compound decomposes into its elements to form either a solid solution or react with gaseous hydrogen, oxygen, or water ${ }^{91,92,93}$. Therefore, the direct carbon oxidation described in Equation 5.10 is a probable approximation to all direct carbon reaction pathways. The complete oxidization of $150 \mathrm{ppm}$ benzene in the fuel stream would require $8.92 \mathrm{~mA}$, and the complete oxidation of 500 ppm naphthalene would require $30.4 \mathrm{~mA}$, so there is sufficient current density to facilitate the hydrocarbon oxidation.

The potential increases that are observed upon addition of the hydrocarbons, may arise from direct oxidation of the hydrocarbons or oxidation of carbon species, with the direct oxidation mechanisms producing 132-182 $\mathrm{mV}$ of additional cell potential with syngas fuel. Naphthalene exposure of $100 \mathrm{ppm}$ is observed to generate a $12 \mathrm{mV}$ increase in the cell output. This potential increase is derived from some increase in concentration of reformed fuel molecules, or through more direct reaction pathways. Complete reforming of naphthalene to $\mathrm{H}_{2}$ and $\mathrm{CO}_{2}$ would increase the fuel molecules by $118 \mathrm{ppm}$, for a total increase in the fuel concentration approximately $0.01 \%$. This magnitude of fluctuation is not expected to produce a recordable 
potential change, especially in the low fuel utilization conditions used in the present tests $(\sim 2.0 \%)$. Based on the magnitude of observed potential increase, it seems likely that direct oxidation of the fuel and/or oxidation of residual surface carbon are responsible for the increase in potential.

\subsection{Discussion of Data}

Considering only the shapes of the curves obtained experimentally when hydrocarbons are added, the following conclusions can be drawn. The degradation mechanism is likely Class I or Class IIIB. The exponential decay single-phase models fit the data the best. The Class II and Class IIIA mechanisms are unlikely due to the lack of microstructure damages in the Ni-YSZ matrix.

For either Class I or Class IIIB to be likely mechanisms of attack for hydrocarbon contaminant species, there should be detectable carbon in the pore structure or in solution with the nickel metal. However, XPS and SEM did not detect any carbon in either location. Thus, a reverse process that consumes carbon must be occurring.

In the case of benzene, degradation is zero order with respect to concentration in the range of 15 to $150 \mathrm{ppm}$, meaning that the degradation rate was independent of concentration in this range. This being the case, the mechanism of attack must be limited by the diffusion of carbon into the nickel structure. Zero order degradation indicates that at this concentration range, the mechanism does not involve gas phase transport. There are six carbon atoms per molecule of benzene. At these low concentrations, 90 and $900 \mathrm{ppm}$ carbon atoms are available for deposition, assuming complete decomposition of the benzene molecule. Because the degradation in this case is zero order, it is likely that the mechanism is Class IIIB in this carbon concentration range. 
Naphthalene, on the other hand, has ten carbon atoms per molecule. XPS was able to detect some carbon above background in the case of naphthalene. The naphthalene concentration for the two tests was 100 and 500 ppm, meaning that between 1000 and 5000 ppm carbon, a Class I degradation mechanism is occurring. The carbon attack mechanism is therefore dependent on the amount of atomic carbon loaded in the fuel stream.

Considering these mechanisms, the behavior as the cells operate up to $40,000 \mathrm{~h}$ will be as follows: The typical curve for Class I and Class IIIB is an exponential decay, as predicted by the experimental data. At long time, $t$, it is expected that the degradation due to hydrocarbon interaction will reach an equilibrium state (with reversible reactions) at the time predicted by the crossover time, $t_{c}$. After this point, the thermochemical degradation will continue until the increase in cell overpotential causes too great a decrease in efficiency. At larger concentrations, there may be a complete failure due to coking at some point before $40,000 \mathrm{~h}$ of operation.

The formation of $\mathrm{Ni}_{3} \mathrm{C}$ is feasible at fuel cell operating conditions, as shown in the $\mathrm{Ni}-\mathrm{C}$ phase diagram given in Figure 5.12. Note that at $800^{\circ} \mathrm{C}$, small concentrations of carbon (2.7 at\% C will dissolve in $\mathrm{Ni}$ ) will produce $\mathrm{Ni}_{3} \mathrm{C}$. 


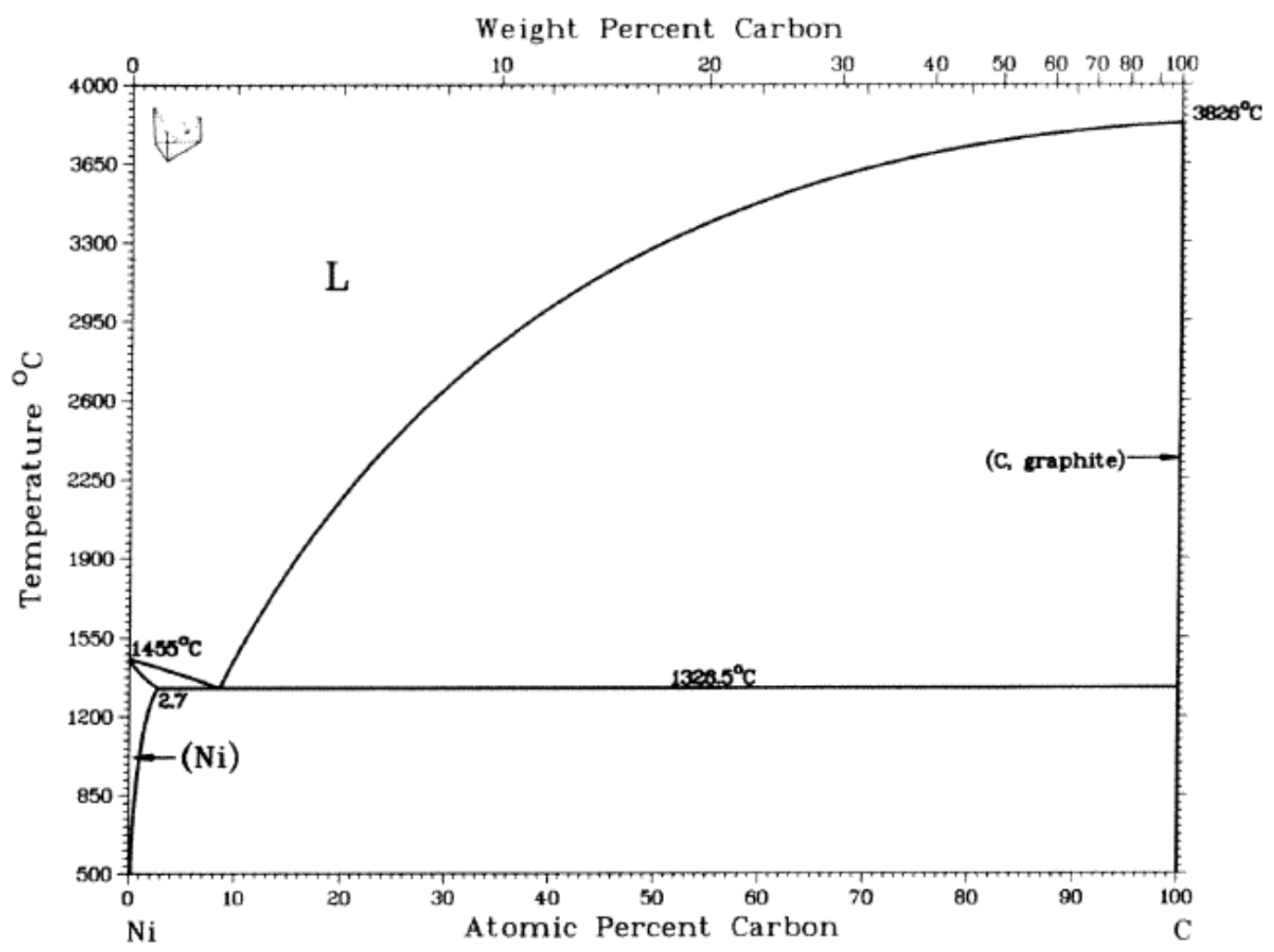

Figure 5.12 - Nickel-carbon phase diagram.

Carbon deposition in the nickel catalyst is expected to be slightly different. Re-visiting Equation 2.29 as proposed by Zhang et al., the predicted rate of carbon deposition for a $\mathrm{CO} / \mathrm{H}_{2}$ mixture is given as:

$$
r=r_{1}+r_{2}-r_{3}=k_{1} p_{\mathrm{CO}} p_{\mathrm{H}_{2}}+k_{2} p_{\mathrm{CO}}^{2}-k_{3} p_{H_{2}}^{2}
$$

It is necessary to note that Zhang et al. used a minimal amount of steam in their experiment (about $1 \% \mathrm{H}_{2} \mathrm{O}$ ). This small amount of steam is not likely to shift the gas toward carbon dioxide and hydrogen by the WGS reaction, leaving more carbon monoxide that tends to precipitate carbon, according to Equation 2.23. 


\section{CHAPTER SIX - POSTULATED MECHANISMS OF HYDROCARBON ATTACK}

\subsection{Deposition Mechanism}

Application of the single-phase exponential decay model produced the best regressive fit to the naphthalene and benzene data, which supports a degradation mechanism consisting of a strong initial decay followed by stabilization of the degradation rate. Treatment of degradation as a single-phase exponential decay process is not likely to produce accurate lifetime degradation rates, since the output is predicted to plateau at some value as time approaches infinity. More realistically, the initial decay should be attributed to a combination of hydrocarbon exposure and thermal decomposition, with subsequent decay rates attributed to thermal cell degradation processes only. The dual-phase model is more realistic over long periods of time, but the contaminant effects are confined to the first phase of degradation only.

The form of the deposited carbon may be the following. ${ }^{94,95,96}$ Pyrolytic carbon is usually formed by thermal cracking of hydrocarbons above $600^{\circ} \mathrm{C}$ when carbon intermediates are present. Whisker carbon is produced by diffusion of carbon into nickel crystals, detachment of nickel from the support and growth of whiskers with nickel at the tip of the growing whisker above $450^{\circ} \mathrm{C}$. Encapsulating carbon is not expected to be present because it is formed by slow polymerization of unsaturated hydrocarbons below $500^{\circ} \mathrm{C}$.

The postulated mechanism describes a process by which carbon deposits on the Ni-YSZ surface and then diffuses into the nickel structure. At some equilibrium value, carbon will stop diffusing into nickel and will accumulate on the surface, coking the pores.

Hydrocarbons (in the form $\mathrm{C}_{\mathrm{x}} \mathrm{H}_{\mathrm{y}}$ ) likely adsorb onto the Ni-YSZ surface and react to form gaseous products or a macromolecular intermediate (of the form $\mathrm{CH}_{\mathrm{z}}$, with $\mathrm{z}$ being between 0.5 
and 1). This macromolecule is considered to be produced and consumed at some equilibrium value, under the pseudo-steady state assumption (PSSA), and is not expected to become stable. The intermediate moves across the Ni-YSZ surface and deposits on a vacant nickel reaction site. This process continues until a carbon deposit is formed. Once the carbon has deposited it diffuses into the Ni-YSZ pore structure blocking fuel flow channels and active reaction sites, effectively diminishing cell performance.

Assuming the postulated two-step process, the reaction schematic is given as the following:

$$
\mathrm{C}_{x} \mathrm{H}_{y} \stackrel{\mathrm{r}_{1}}{\rightarrow} \mathrm{CH}_{z} \stackrel{r_{2}}{\rightarrow} \mathrm{C}
$$

The formation of the intermediate carbon phase is given in Equation 6.2. Assuming that $r_{2}$ is very fast, the pseudo-steady-state assumption applies making the rate of formation equal to zero.

$$
\frac{d\left(\mathrm{CH}_{\mathrm{z}}\right)}{d t}=r_{1}-r_{2}=0(P S S A)
$$

The deposition of carbon is given in Equation 6.3. Because the rate of formation of carbon is dependent upon the available nickel reaction sites, $N$, the carbon deposition rate is proportional to the initial intermediate formation rate.

$$
\frac{d C}{d t}=r_{2}=r_{1}=\frac{N}{N_{0}} r_{0}
$$

The rate of change of available reaction sites is equal to the loss of active sites due to $r_{2}$. Therefore, the following relationship can be developed. A conversion coefficient, $\delta$, is a conversion factor required to convert from carbon concentration, $C$, to active nickel site concentration, $N$.

$$
\Delta N=-r_{2} \Delta t \delta \frac{N}{N_{0}}
$$

where

$$
\delta=\frac{N_{0}\left(N-N_{0}\right)}{C N}
$$


When $\Delta \mathrm{t} \rightarrow 0$ and Equation 6.3 is substituted into Equation 6.4, the relationship can be rewritten as:

$$
\frac{d N}{d t}=-\delta \frac{N}{N_{0}} \frac{d C}{d t}
$$

Integrating Equation 6.6 gives:

$$
\frac{N}{N_{0}}=e^{-\frac{\delta}{N_{0}} C}
$$

When $N / N_{0}$ reaches zero, it is assumed that there is no further reaction activity, and fuel cell performance drops to zero. Experimental results show that the degradation due to carbon deposition stops at a point before cell performance reaches zero. Therefore, an equilibrium carbon deposition is reached at the experimental conditions.

To determine this equilibrium value, values must be determined within the relationship described in Equation 6.7 by assuming that the maximum carbon deposition possible is 0.11 grams of carbon per gram of Ni-YSZ, since the density of Ni-YSZ is taken to be $4200 \mathrm{~kg} / \mathrm{m}^{3}$ and the density of coke $440.5 \mathrm{~kg} / \mathrm{m}^{3}$.

$$
\frac{440.5 \mathrm{~kg} / \mathrm{m}^{3}}{4200 \mathrm{~kg} / \mathrm{m}^{3}}=0.11
$$

Experiments have shown that the maximum carbon deposition on pure nickel catalysts is $0.16 \mathrm{~g} \mathrm{C}$ g-catalyst $^{97}$, so this assumption is valid considering the density of nickel catalyst is $2835 \mathrm{~kg} / \mathrm{m}^{3}$. Assuming that when the catalyst is only 1\% active, the pores will be completely plugged with deposited carbon. In this case, Equation 6.7 can be solved to find that $-\delta / N_{0}=41.9$ g Ni-YSZ / g C.

The experimental potential drop due to the predicted carbon deposition is provided below in Table 6.1. 
Table 6.1 - Summary of Performance Decrease for Each Hydrocarbon Experiment Conducted and the Predicted Carbon Deposition per gram of Ni-YSZ

\begin{tabular}{|c|c|c|}
\hline Test & $\begin{array}{c}\text { Output Decrease Due } \\
\text { to Carbon Deposition }\end{array}$ & $\begin{array}{c}\text { Predicted Carbon } \\
\text { Deposition } \\
\text { [g C / g Ni-YSZ }\end{array}$ \\
\hline $100 \mathrm{ppm}$ Naphthalene & $17 \mathrm{mV}(2.3 \%)$ & $5.6 \times 10^{-4}$ \\
\hline $500 \mathrm{ppm}$ Naphthalene & $50 \mathrm{mV}(6.4 \%)$ & $1.6 \times 10^{-3}$ \\
\hline $15 \mathrm{ppm}$ Benzene & $12 \mathrm{mV}(1.4 \%)$ & $3.4 \times 10^{-4}$ \\
\hline $150 \mathrm{ppm}$ Benzene & $12 \mathrm{mV}(1.4 \%)$ & $3.4 \times 10^{-4}$ \\
\hline
\end{tabular}

Based on the predicted performance degradations, it is found that anywhere from $0.3-1.6$ mg of carbon is deposited in the pores or on the surface of the fuel cell anode (assuming about 1 g Ni-YSZ present in the active area).

A two-step mechanism is proposed to explain trends obtained from exposing SOFC button cells with HHCs. With the values determined from the proposed degradation model, a theoretical carbon deposition is predicted from experimental potential degradation. The predicted values are about two orders of magnitude lower than Zhang et al., for the reasons discussed in Section 5.3.

\subsection{Carbon Diffusion Mechanism}

Once the carbon has started depositing on the catalyst surface, it will diffuse into the nickel structure. At lower temperatures, carbon will diffuse into the nickel lattice to form a stable carbide $\left(\mathrm{Ni}_{3} \mathrm{C}\right)$. This necessary minimum temperature is due to the activation energy $(1.5 \mathrm{eV})$ required for carbon diffusion in bulk nickel. The free energy of formation for $\mathrm{Ni}_{3} \mathrm{C}$ at room temperature is positive. Carbon will dissolve into $\mathrm{Ni}(100)$ first because of the relatively open surface structure. 
Wiltner et al. ${ }^{98,99}$ proposed a mechanism by which surface deposited carbon diffuses into the nickel structure. The group deposited graphitic carbon layers onto a nickel surface at room temperature and then heated the sample slowly up to $700^{\circ} \mathrm{C}$. The correlation between the total thickness of the deposited carbon, $d_{C 1 s}$ and the kinetic parameter, $k_{D}$ is given in Equation 6.9:

$$
-\frac{d\left[d_{C 1 s}\right]}{d t}=k_{D}(T) d_{C 1 s} \rightarrow \ln \frac{d_{C 1 s}}{d_{C 1 s, 0}}=-k_{D}(T) t
$$

with $d_{C 1 s}$ being the carbon layer thickness at time, $t$, and temperature, $T$, and $d_{C 1 s, 0}$ being the initial carbon layer thickness at temperature, $T$. Therefore, the group assumes a first order reaction for carbon diffusion. Assuming Arrhenius behavior of $k_{D}(T)$, the activation barrier for carbon subsurface diffusion can be determined, as shown in Equation 6.10:

$$
k_{D}(T)=k_{0} \exp \left(-\frac{E_{D}}{k_{B} T}\right)
$$

where $k_{0}$ is the pre-exponential factor, $E_{D}$ is the activation energy for diffusion, and $k_{B}$ is the Boltzmann constant. The reactions are demonstrated in Figure 6.1. 


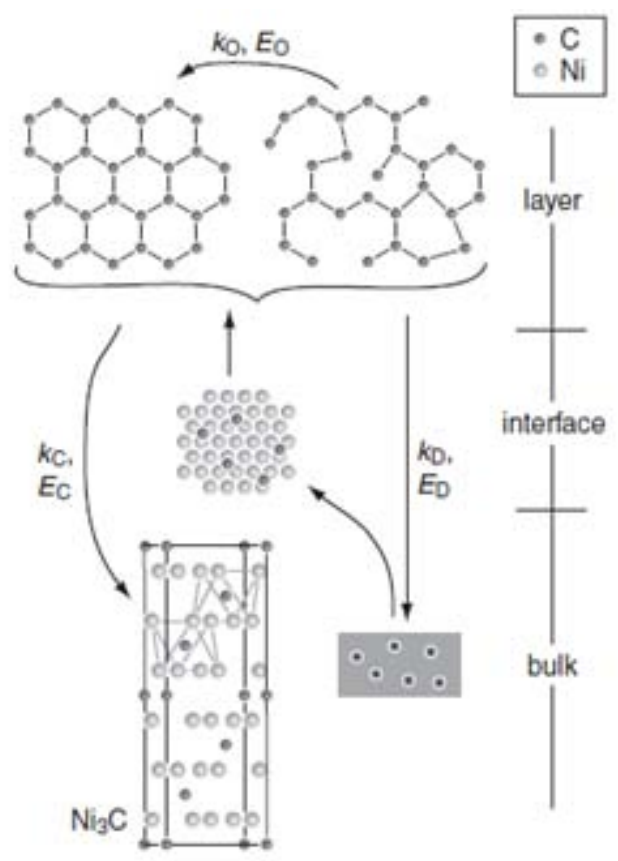

Figure 6.1 - Illustration of the reactions identified for carbon diffusion into nickel (111). ${ }^{99}$

Therefore, the group proposes that carbon does diffuse into the nickel lattice structure in the following manner. Decomposition of the initially formed carbide leads to an increase in elemental carbon. The ordering reaction within the elemental carbon leads to a decrease in disordered graphitic carbon. Carbon subsurface diffusion and carbide reformation leads to a decrease in the graphitic elemental carbon. These reaction steps show how carbon diffuses into nickel and how the phenomena can be detected with XPS by watching the 1s elemental carbon peak level.

\subsection{Carbon Induced Nickel Corrosion}

Under conditions of high carbon activity, carbon can corrode nickel by a process called metal dusting. In this process, the nickel anode corrodes by a combination of carbon diffusion and precipitation in the bulk metal and atom migration through surface carbon deposits. At 
temperatures around $350^{\circ} \mathrm{C}$, nickel forms $\mathrm{Ni}_{3} \mathrm{C}$, which is stable and does not contribute to the corrosion mechanism.

Chun et al. ${ }^{81}$ reported that at a $\mathrm{CO} / \mathrm{H}_{2}$ ratio of $25: 1$, surface graphite deposition followed by intercalation of $\mathrm{Ni}$ atoms into the graphite is the main corrosion mechanism. The perpendicular alignment of the graphite planes to the $\mathrm{Ni}$ surface favors such intercalation. Ni atoms can coalesce at the outer surface of graphite to form Ni particles, which catalyze the formation of filamentous carbon and are carried away. At a $\mathrm{CO} / \mathrm{H}_{2}$ ratio of $1: 1$, in addition to the above mechanism, a corrosion mechanism occurs which involves the diffusion of carbon into the nickel lattice followed by graphite precipitation within the bulk. Because the solubility of carbon in nickel is low, a supersaturated point is easily reached. When the precipitation is profuse enough, complete disintegration of the nickel specimen results. These experiments were conducted at $750^{\circ} \mathrm{C}$.

\subsection{Carbon Removal (Reverse) Mechanism}

Post-trial analysis did not detect any carbon above background levels for the benzene exposure. In addition, only a small amount of carbon was detected in the cells exposed to naphthalene. Therefore, there must be a reverse mechanism that consumes the carbon from the fuel cell. However, it is possible that the carbon could still be in a solution that is undetectable by the microanalysis methods used. It is also possible that the carbon levels were too low to detect or that no carbon ever deposited. The last scenario is unlikely because of the observed increased degradation rate upon exposure to hydrocarbons. Carbon consumption is most likely to happen during the cell cool-down phase. The cool-down phase is very fast ( 15 min) in order to capture as much carbon in the cell as possible. 
The experimental setup was designed to obtain performance curves based on a steady initial output and not for optimal cell performance values. Therefore, the system has small leaks due to the mica seals not being gas-tight. Oxygen from the atmosphere is causing deposited carbon to oxidize to carbon dioxide by the following reaction:

$$
\mathrm{C}+\mathrm{O}_{2} \stackrel{r_{3}}{\rightarrow} \mathrm{CO}_{2}
$$

Also, steam present in the fuel feed stream reacts with carbon deposits to gasify the carbon to form carbon monoxide and hydrogen:

$$
\mathrm{C}+\mathrm{H}_{2} \mathrm{O} \stackrel{r_{4}}{\rightarrow} \mathrm{CO}+\mathrm{H}_{2}
$$

These reactions are the expected reversible reactions for Class I degradation. With these competing reactions occurring simultaneously, an equilibrium amount of carbon is deposited, which is consistent with experimental results. At equilibrium, a steady-state value is reached:

$$
\frac{d C}{d t}=r_{2}-\left(r_{3}+r_{4}\right)=0
$$

Prior to equilibrium, $r_{2}$ is larger than the sum of $r_{3}$ and $r_{4}$, but as the experiment progresses, they reach equilibrium. This would be modeled as an exponential decay model, which is consistent with cell lifetime predictions proposed in the previous sections. During the experiment it is expected that $r_{4}>>r_{3}$ because $p_{\mathrm{H} 2 \mathrm{O}}>>p_{\mathrm{O} 2}$.

When fuel flow is stopped ( $\mathrm{N}_{2}$ is supplied instead), equilibrium is interrupted. At this point, $p_{\mathrm{O} 2}>>p_{\mathrm{H} 2 \mathrm{O}}$, meaning that Reaction 6.11 takes over. The cell cool-down period is not rapid enough to capture carbon in the cell, as results indicate that all of the carbon is consumed prior to analysis. This indicates a very rapid rate of carbon removal. Table 6.2 indicates the deposition and removal rates of carbon for each hydrocarbon experiment. The removal rate is three to four orders of magnitude faster than the deposition rate. The average removal rate is $2.4 \times 10^{-3} \mathrm{~g} / \mathrm{h}$. 
Table 6.2 - Carbon Deposition and Removal Rates for Each Hydrocarbon Experiment

\begin{tabular}{|c|c|c|}
\hline Experiment & $\begin{array}{c}\text { Rate of Carbon Deposition } \\
{[\mathrm{g} / \mathrm{h}]}\end{array}$ & $\begin{array}{c}\text { Rate of Carbon Removal* } \\
{[\mathrm{g} / \mathrm{h}]}\end{array}$ \\
\hline $100 \mathrm{ppm}$ Naphthalene & $1.26 \times 10^{-6}$ & $>2.0 \times 10^{-3}$ \\
\hline $500 \mathrm{ppm}$ Naphthalene & $2.61 \times 10^{-6}$ & $>5.2 \times 10^{-3}$ \\
\hline $15 \mathrm{ppm}$ Benzene & $6.20 \times 10^{-7}$ & $>1.2 \times 10^{-3}$ \\
\hline $150 \mathrm{ppm}$ Benzene & $5.40 \times 10^{-7}$ & $>1.2 \times 10^{-3}$ \\
\hline
\end{tabular}

*- Rates are supplied as “greater than” because a cool-down period of less than 15 min was not possible.

This mechanism is postulated as a method of attack of carbon on a Ni-YSZ fuel cell anode.

The two-step degradation mechanism is proposed to explain trends obtained from exposing SOFC button cells with HHCs. The carbon is proposed to deposit onto the surface and slowly diffuse into the nickel lattice structure. Considering the reversibility of this mechanism, it is expected that an equilibrium condition be established. This method predicts and describes results obtained from cell performance curves and can be used to predict the theoretical amount of carbon deposited in the pore structure as a function of cell performance loss. 


\section{CHAPTER SEVEN - CONCLUSIONS}

In coal gasification processes, coal can be converted into a high-quality gaseous fuel suitable for feeding solid oxide fuel cells (SOFCs). However, trace species found in coal synthesis gas (syngas) may have a deleterious effect on the performance of nickel-based SOFC anodes.

The purpose of this research was to determine the highest amount of contaminant that results in a low rate of cell performance degradation, such that the cell can produce usable power ( 0.6 or 0.7 V) for 40,000 hours.

SOFC exposed to mercury at 1 and $10 \mathrm{ppm}$ did not show any performance degradation that could not be attributed to natural cell function. This result is in agreement with thermodynamic analyses and results found in the literature. Further cleanup of mercury is not required for fuel cell operation.

SOFC exposed to benzene at 15 and $150 \mathrm{ppm}$ showed noticeable, but small, performance degradation. Due to the similarity in the degradation rates, as fitted with a dual-phase degradation model, an accurate concentration prediction could not be made for benzene. A conservative estimate of a cleanup concentration of less than $150 \mathrm{ppm}$ will produce a useable potential of $0.6 \mathrm{~V}$ after $40,000 \mathrm{~h}$ of operation considering a baseline thermal degradation rate of $0.25 \%$ per $1000 \mathrm{~h}$ with a lesser concentration functioning at $0.7 \mathrm{~V}$. A potential of $0.6 \mathrm{~V}$ will be produced at a baseline cell degradation rate of $0.50 \%$ per $1000 \mathrm{~h}$ with less than $150 \mathrm{ppm}$ benzene.

SOFC exposed to naphthalene at 150 and 500 ppm showed marked performance degradation, with rates higher than those for benzene. A dual-phase degradation mechanism most accurately reflects cell performance, with the initial phase being exponential decay due to hydrocarbon exposure and thermal TPB degradation. The second phase is degradation due solely to the 
thermal degradation of the TPB. After $40,000 \mathrm{~h}$, the SOFC will produce usable potential of 0.7 $\mathrm{V}$ at $110 \mathrm{ppm}$, when using a baseline cell degradation rate of $0.25 \%$ per $1000 \mathrm{~h}$. A naphthalene concentration of $1200 \mathrm{ppm}$ will produce a potential of $0.6 \mathrm{~V}$ using the same baseline cell degradation rate. When considering a baseline cell degradation rate of $0.50 \%$ per $1000 \mathrm{~h}$, less than $360 \mathrm{ppm}$ naphthalene will allow a SOFC to operate at $0.6 \mathrm{~V}$ after $40,000 \mathrm{~h}$.

A detailed attack and recovery mechanism is proposed for the hydrocarbon species and their interaction with the fuel cell. This mechanism takes into consideration the predicted decay models as well as the lack of any detectable carbon during post-trial analysis. The mechanism describes carbon surface deposition with resulting carbon propagation into the pore structure. The mechanism postulates that physical pore blockage and active reaction site adsorption are responsible for performance losses.

This work identifies the complexity of determining degradation mechanisms and cleanup targets for coal contaminant species from syngas. It demonstrates a technique by which physical degradation processes can be identified by the shape of potential versus time curves. It supplies a method to predict cell behavior over long periods of time $(\sim 40,000 \mathrm{~h})$ by analyzing data from $500 \mathrm{~h}$ exposure periods. It also describes a carbon attack mechanism that can be used to predict how carbon interacts with anode components, which will lead to better experimental design and the choice of optimum operating conditions. 


\section{CHAPTER EIGHT - RECOMMENDATIONS}

As with any research, there are likely a few "next steps” for continuation of the research. Thus, the following recommendations are presented for consideration.

- Statistically significant experimental data of long-term thermal degradation of SOFCs operating with syngas fuel need to be obtained. For this information to be helpful to researchers, a standard method of cell manufacturing (technique, materials, etc.) should be determined so that an accurate thermal degradation rate can be assessed and applied uniformly to all cells.

- It is possible to introduce a GC/ICP-MS system for analysis of a fuel flow sample prior to being exposed to the SOFC. This equipment was in the process of being added to the test apparatus. However, the calibration and analysis method was not completed in time for use in this research. The system was used for "qualitative analysis” to confirm that mercury was flowing in to the SOFC; however, the exact concentration could not be quantified accurately. The system could be used for the hydrocarbons as well.

- A different method for cool-down is necessary to capture any carbon within the cell structure or on its surface. SEM and XPS were not able to detect any appreciable carbon within the cell, even though cell performance degradation models suggest that carbon deposition is responsible for initial cell degradation. Also, ToF-SIMS and TEM may be possible analytical techniques to detect carbon, but it is likely that any deposited carbon is converted to $\mathrm{CO}_{2}$ prior to analysis.

- Impedance analysis results were too sporadic and noisy to obtain any meaningful data. A new analysis technique should be considered for the future so that 
resistances can be monitored more consistently as most of the impedance results are difficult to explain. In addition, a method by which impedance measurements can be taken without removing the current load may be more helpful in analyzing true cell degradation behavior. Also, impedance data should be taken much more often.

- Additional testing must be completed in order to validate the postulated carbon attack mechanism. This also depends on improvement of the previously mentioned analytical techniques before any results will support the postulated mechanism.

- Additional testing must be completed in order to obtain results that are more accurate for cleaning syngas of benzene. Additional tests at different concentrations are recommended.

- Further research needs to be conducted on other syngas contaminant species to postulate additional reaction mechanisms. There are plenty of data available in the literature to make a postulated mechanism, which can then be validated through additional experimentation and analysis.

- Experimentation would be much more time effective if multiple cells could be exposed to the contaminated syngas at once. This would provide more reliable and statistically significant results. These so-called "Multi-Cell Arrays" are already in development by the National Energy Technology Laboratory in Morgantown, WV and are recommended for multiple cell testing. 


\section{CHAPTER NINE - BIBLIOGRAPHY}

1. Coal Reserves. http://www.eia.doe.gov/neic/infosheets/coalreserves.html.

2. $\quad$ NETL Clean Coal Power Initiative Fact Sheet.

http://www.fossil.energy.gov/programs/powersystems/cleancoal/ccpi/Prog052.pdf.

3. Energy, U. S. D. o. Recovery and Reinvestment. http://www.energy.gov/recovery/.

4. $\quad$ Higman, C.; van der Burgt, M., Gasification. Elsevier: 2003.

5. Scott, D. H.; Carpenter, A. M. Advanced power systems and coal quality; IEA Coal Research: London, 1996.

6. Singhal, S. C., Advances in solid oxide fuel cell technology. Solid State Ionics 2000, 135 (1-4), 305-313.

7. Sun, C. W.; Stimming, U., Recent anode advances in solid oxide fuel cells. Journal of Power Sources 2007, 171 (2), 247-260.

8. Haile, S. M., Fuel cell materials and components. Acta Materialia 2003, 51 (19), 59816000 .

9. $\quad$ Horita, T.; Kishimoto, H.; Yamaji, K.; Xiong, Y. P.; Sakai, N.; Brito, M. E.; Yokokawa, H., Materials and reaction mechanisms at anode/electrolyte interfaces for SOFCs. Solid State Ionics 2006, 177 (19-25), 1941-1948.

10. Kuchonthara, P.; Bhattacharya, S.; Tsutsumi, A., Combination of thermochemical recuperative coal gasification cycle and fuel cell for power generation. Fuel 2005, 84 (7-8), 1019-1021.

11. Van Osdol, J. G.; Gemmen, R.; Parsons, E. In Using staged compression to increase the system efficiency of a coal cased gas turbine fuel cell hybrid power generation system with carbon capture, ASME Power 2008, Orlando, FL, Orlando, FL, 2008.

12. Kivisaari, T.; Bjornbom, P.; Sylwan, C.; Jacquinot, B.; Jansen, D.; de Groot, A., The feasibility of a coal gasifier combined with a high-temperature fuel cell. Chemical Engineering Journal 2004, 100 (1-3), 167-180.

13. Ratafia-Brown, J.; Manfredo, L.; Hoffmann, J.; Ramezan, M. Major Environmental Aspects of Gasification-Based Power Generation Technologies, Final Report; U.S. Department of Energy: 2002; pp 39-59.

14. Gasified coal success for Delphi SOFC. Fuel Cells Bulletin 2003, 2003 (11), 2. 
15. Lohsoontorn, P.; Brett, D. J. L.; Brandon, N. P., Thermodynamic predictions of the impact of fuel composition on the propensity of sulphur to interact with $\mathrm{Ni}$ and ceria-based anodes for solid oxide fuel cells. Journal of Power Sources 2008, 175 (1), 60-67.

16. Trembly, J. P.; Gemmen, R. S.; Bayless, D. J., The effect of IGFC warm gas cleanup system conditions on the gas-solid partitioning and form of trace species in coal syngas and their interactions with SOFC anodes. Journal of Power Sources 2007, 163 (2), 986-996.

17. NETL, Fuel Cell Handbook. 2004; Vol. Seventh Edition.

18. Trembly, J.; Albritton, J.; Gupta, R., A Review of Coal Syngas Cleanup Technologies, Past Trace Contaminant Testing, and Future SOFC Testing Activities at RTI. In Coal Based Fuel Cell Technology, Morgantown, WV, 2007.

19. Williams, M. C.; Strakey, J.; Sudoval, W., U.S. DOE fossil energy fuel cells program. Journal of Power Sources 2006, 159 (2), 1241-1247.

20. Trembly, J. P.; Marquez, A. I.; Ohrn, T. R.; Bayless, D. J., Effects of coal syngas and H2S on the performance of solid oxide fuel cells: Single-cell tests. Journal of Power Sources 2006, 158 (1), 263-273.

21. Laurencin, J.; Lefebvre-Joud, F.; Delette, G., Impact of cell design and operating conditions on the performances of SOFC fuelled with methane. Journal of Power Sources 2008, 177 (2), 355-368.

22. Suwanwarangkul, R.; Croiset, E.; Entchev, E.; Charojrochkul, S.; Pritzker, M. D.; Fowler, M. W.; Douglas, P. L.; Chewathanakup, S.; Mahaudom, H., Experimental and modeling study of solid oxide fuel cell operating with syngas fuel. Journal of Power Sources 2006, 161 (1), 308-322.

23. Cheng, Z.; Zha, S.; Liu, M., Influence of cell voltage and current on sulfur poisoning behavior of solid oxide fuel cells. Journal of Power Sources 2007, 172 (2), 688-693.

24. Trembly, J. P.; Gemmen, R. S.; Bayless, D. J., The effect of coal syngas containing HCl on the performance of solid oxide fuel cells: Investigations into the effect of operational temperature and HCl concentration. Journal of Power Sources 2007, 169 (2), 347-354.

25. Gangwal, S. K.; Gupta, R.; McMichael, W. J., Hot-gas cleanup - Sulfur recovery technical, environmental, and economic issues. Heat Recovery Systems \& Chp 1995, 15 (2), 205214.

26. Gemmen, R. S.; Trembly, J., On the mechanisms and behavior of coal syngas transport and reaction within the anode of a solid oxide fuel cell. Journal of Power Sources 2006, 161 (2), 1084-1095. 
27. Colpan, C. O.; Dincer, I.; Hamdullahpur, F., Thermodynamic modeling of direct internal reforming solid oxide fuel cells operating with syngas. International Journal of Hydrogen Energy 2007, 32 (7), 787-795.

28. Laudal, D. L.; Thompson, J. S.; Pavlish, J. H.; Brickett, L. A.; Chu, P., Use of continuous mercury monitors at coal-fired utilities. Fuel Processing Technology 2004, 85 (6-7), 501-511.

29. Pavlish, J. H.; Sondreal, E. A.; Mann, M. D.; Olson, E. S.; Galbreath, K. C.; Laudal, D. L.; Benson, S. A., Status review of mercury control options for coal-fired power plants. Fuel Processing Technology 2003, 82 (2-3), 89-165.

30. Takematsu, T. i.; Maude, C. Coal gasification for IGCC power generation; IEA Coal Research: London, 1991.

31. Helble, J. J.; Mojtahedi, W.; Lyyranen, J.; Jokiniemi, J.; Kauppinen, E., Trace element partitioning during coal gasification. Fuel 1996, 75 (8), 931-939.

32. Everitt, E.; Bissett, L. A. NETL's Gas Process Development Unit for Hot/Warm Gas Cleanup; U.S. Department of Energy: 2002; pp 1-5.

33. Park, N. K.; Lee, D. H.; Jun, J. H.; Lee, J. D.; Ryu, S. O.; Lee, T. J.; Kim, J. C.; Chang, C. H., Two-stage desulfurization process for hot gas ultra cleanup in IGCC. Fuel 2006, 85 (2), 227-234.

34. Bu, X. P.; Ying, Y. J.; Ji, X. G.; Zhang, C. Q.; Peng, W. W., New development of zincbased sorbents for hot gas desulfurization. Fuel Processing Technology 2007, 88 (2), 143-147.

35. Bu, X. P.; Ying, Y. J.; Zhang, C. Q.; Peng, W. W., Research improvement in Zn-based sorbent for hot gas desulfurization. Powder Technology 2008, 180 (1-2), 253-258.

36. Schmidt, R.; Tsang, A.; Cross, J.; Summers, C.; Kornosky, B., Laboratory simulated slipstream testing of novel sulfur removal processes for gasification application. Fuel Processing Technology In Press, Corrected Proof.

37. Tsukada, M.; Abe, K.; Yonemochi, Y.; Arneyama, A.; Kamiya, H.; Kambara, S.; Moritomi, H.; Uehara, T., Dry gas cleaning in coal gasification systems for fuel cells using composite sorbents. Powder Technology 2008, 180 (1-2), 232-238.

38. Krishnan, G. N. Effect of coal contaminants on solid oxide fuel system performance and service life; SRI International: Morgantown, WV, 2006.

39. Clarke, L. B.; Sloss, L. L. Trace elements - emissions from coal combustion and gasification; IEA Coal Research: London, 1992.

40. Koide, H.; Someya, Y.; Yoshida, T.; Maruyama, T., Properties of Ni/YSZ cermet as anode for SOFC. Solid State Ionics 2000, 132 (3-4), 253-260. 
41. Trembly, J. P.; Gemmen, R. S.; Bayless, D. J., The effect of coal syngas containing AsH3 on the performance of SOFCs: Investigations into the effect of operational temperature, current density and AsH3 concentration. Journal of Power Sources 2007, 171 (2), 818-825.

42. Trembly, J. P.; Gemmen, R. S.; Bayless, D. J., The Effect of Trace As, Cl, P, and Se Coal Syngas Species on the Performance of a Planar Solid Oxide Fuel Cell. In 5th Fuel Cell Science, Engineering, and Technology Conference, ASME: New York, NY, 2007.

43. Matsuzaki, Y.; Yasuda, I., The poisoning effect of sulfur-containing impurity gas on a SOFC anode: Part I. Dependence on temperature, time, and impurity concentration. Solid State Ionics 2000, 132 (3-4), 261-269.

44. Marquez, A. I.; Ohrn, T. R.; Trembly, J. P.; Ingram, D. C.; Bayless, D. J., Effects of coal syngas and H2S on the performance of solid oxide fuel cells: Part 2. Stack tests. Journal of Power Sources 2007, 164 (2), 659-667.

45. $\quad$ Lussier, A.; Sofie, S.; Dvorak, J.; Idzerda, Y. U., Mechanism for SOFC anode degradation from hydrogen sulfide exposure. International Journal of Hydrogen Energy In Press, Corrected Proof.

46. Choi, Y. M.; Compson, C.; Lin, M. C.; Liu, M., A mechanistic study of H2S decomposition on $\mathrm{Ni}$ - and $\mathrm{Cu}$-based anode surfaces in a solid oxide fuel cell. Chemical Physics Letters 2006, 421 (1-3), 179-183.

47. Gerdes, K.; Trembly, J.; Gemmen, R., Effect of H2Se Exposure on Performance of Anode Supported SOFC. In Symposium on Coal Based Fuel Cell Technology, National Institute of Fuel Cell Technology: Morgantown, WV, 2007.

48. Marina, O. A.; Pederson, L. R.; Edwards, D. J.; Coyle, C. W.; Templeton, J.; Engelhard, M.; Zhu, Z., SOFC Operation on Hydrogen and Coal Gas in the Presence of Phosphorus, Arsenic, and Sulfur Impurities. In 8th Annual SECA Workshop, San Antonio, TX, 2007.

49. Pederson, L. R.; Marina, O. A.; Zhou, X.-D.; Chou, Y.-S.; Coffey, G. W.; Coyle, C. A.; McCarthy, B. P.; Nguyen, C. D.; Thomsen, E. C. SECA Coal-Based Systems Core Research; U.S. Department of Energy - Office of Fossil Energy Fuel Cell Program: 2007.

50. Nielsen, B.; Villadsen, J., Poisoning of nickel catalysts by arsenic. Applied Catalysis 1984, 11 (1), 123-138.

51. Ng, C. F.; Ye, H.; She, L.; Chen, H.; Lai, S. Y., Arsenic poisoning of nickel catalysts for the adsorption of ethene. Applied Catalysis A: General 1998, 171 (2), 293-299.

52. Ng, C. F.; Chang, Y. J., Arsine poisoning of nickel/silica catalysts : Hydrogen chemisorption study by magnetic method. Applied Catalysis 1991, 70 (1), 213-224. 
53. Ray, E. R.; Maskalick, N. J., Contaminant Effects in Solid Oxide Fuel Cells. In Joint Contractors Meeting: FE/EE Advanced Turbine Systems Conference, FE Fuel Cells, and CoalFired Heat Engines Conference, Morgantown, WV, 1993; pp 1-10.

54. Schmidt, M. S.; Hansen, K. V.; Norrman, K.; Mogensen, M., Effects of trace elements at the Ni/ScYSZ interface in a model solid oxide fuel cell anode. Solid State Ionics In Press, Corrected Proof.

55. Zha, S. W.; Cheng, Z.; Liu, M. L., Sulfur poisoning and regeneration of Ni-based anodes in solid oxide fuel cells. Journal of the Electrochemical Society 2007, 154 (2), B201-B206.

56. $\quad$ Sasaki, K.; Susuki, K.; Iyoshi, A.; Uchimura, M.; Imamura, N.; Kusaba, H.; Teraoka, Y.; Fuchino, H.; Tsujimoto, K.; Uchida, Y.; Jingo, N., H2S poisoning of solid oxide fuel cells. Journal of the Electrochemical Society 2006, 153 (11), A2023-A2029.

57. $\quad$ Novochinskii, I. I.; Song, C.; Ma, X.; Liu, X.; Shore, L.; Lampert, J.; Farrauto, R. J., Low-Temperature H2S Removal from Steam-Containing Gas Mixtures with ZnO for Fuel Cell Application. 1. ZnO Particles and Extrudates. Energy Fuels 2004, 18 (2), 576-583; Novochinskii, I. I.; Song, C.; Ma, X.; Liu, X.; Shore, L.; Lampert, J.; Farrauto, R. J., Low-Temperature H2S Removal from Steam-Containing Gas Mixtures with ZnO for Fuel Cell Application. 2. WashCoated Monolith. Energy Fuels 2004, 18 (2), 584-589.

58. Wang, J.-H.; Liu, M., Computational study of sulfur-nickel interactions: A new S-Ni phase diagram. Electrochemistry Communications 2007, 9 (9), 2212-2217.

59. Choi, Y. M.; Compson, C.; Lin, M. C.; Liu, M., Ab initio analysis of sulfur tolerance of $\mathrm{Ni}, \mathrm{Cu}$, and $\mathrm{Ni}-\mathrm{Cu}$ alloys for solid oxide fuel cells. Journal of Alloys and Compounds 2007, 427 (1-2), 25-29.

60. Cheng, Z.; Liu, M., Characterization of sulfur poisoning of Ni-YSZ anodes for solid oxide fuel cells using in situ Raman microspectroscopy. Solid State Ionics 2007, 178 (13-14), 925-935.

61. Dong, J.; Cheng, Z.; Zha, S.; Liu, M., Identification of nickel sulfides on Ni-YSZ cermet exposed to H2 fuel containing H2S using Raman spectroscopy. Journal of Power Sources 2006, 156 (2), 461-465.

62. Haga, K.; Adachi, S.; Shiratori, Y.; Itoh, K.; Sasaki, K., Poisoning of SOFC anodes by various fuel impurities. Solid State Ionics 2008, 179 (27-32), 1427-1431.

63. Richardson, J. T.; Ortego Jr., J. D.; Coute, N.; Twigg, M. V., Chloride Poisoning of Water-Gas Shift Activity in Nickel Catalysts During Steam Reforming. Catalysis Letters 1996, $41,17-20$. 
64. Bao, J.; Krishnan, G. N.; Jayaweera, P.; Perez-Mariano, J.; Sanjurjo, A., Effect of various coal contaminants on the performance of solid oxide fuel cells: Part I. Accelerated testing. Journal of Power Sources 2009, 193 (2), 607-616.

65. Zhi, M.; Chen, X.; Finklea, H.; Celik, I.; Wu, N. Q., Electrochemical and microstructural analysis of nickel-yttria-stabilized zirconia electrode operated in phosphorus-containing syngas. Journal of Power Sources 2008, 183 (2), 485-490.

66. Xu, C.; Zondlo, J. W.; Finklea, H. O.; Demircan, O.; Gong, M.; Liu, X., The effect of phosphine in syngas on Ni-YSZ anode-supported solid oxide fuel cells. Journal of Power Sources 2009, 193 (2), 739-746.

67. Marina, O.; Pederson, L.; Williams, M.; Coffey, G.; Meinhardt, K.; CD, N.; Thomsen, E., Electrode Performance in Reversible Solid Oxide Fuel Cells. Journal of the Electrochemical Society, 2007; Vol. 154, pp B452-B459.

68. Wojcik, A.; Middleton, H.; Damopoulos, I.; Van herle, J., Ammonia as a fuel in solid oxide fuel cells. Journal of Power Sources 2003, 118 (1-2), 342-348.

69. Dekker, N.; Rietveld, B., Highly Efficient Conversion of Ammonia in Electricity by Solid Oxide Fuel Cells. In Sixth European Solid Oxide Fuel Cell Forum, Energy Innovation: Lucerne, Switzerland, 2004.

70. Steckel, J. A., Density functional theory study of mercury adsorption on metal surfaces. Physical Review B 2008, 77 (11).

71. Devi, L.; Ptasinski, K. J.; Janssen, F. J. J. G., A review of the primary measures for tar elimination in biomass gasification processes. Biomass and Bioenergy 2003, 24 (2), 125-140.

72. $\quad$ Singh, D.; Hernández-Pacheco, E.; Hutton, P. N.; Patel, N.; Mann, M. D., Carbon deposition in an SOFC fueled by tar-laden biomass gas: a thermodynamic analysis. Journal of Power Sources 2005, 142 (1-2), 194-199.

73. Sehested, J., Four challenges for nickel steam-reforming catalysts. Catalysis Today 2006, 111 (1-2), 103-110.

74. Mermelstein, J.; Millan, M.; Brandon, N. P., The impact of carbon formation on Ni-YSZ anodes from biomass gasification model tars operating in dry conditions. Chemical Engineering Science 2009, 64 (3), 492-500.

75. Milne, T. A.; Evans, R. J.; Abatzaglou, N. Biomass Gasifier "Tars": Their Nature, Formation, and Conversion; NREL/TP-570-25357; ON: DE00003726; Other: ON: DE00003726; TRN: US200305\%\%983 United States10.2172/3726Other: ON: DE00003726; TRN: US200305\%\%983Mon Feb 04 15:12:21 EST 2008NREL; RN03021103English; 1998; p Medium: ED; Size: vp. 
76. Coll, R.; Salvadó, J.; Farriol, X.; Montané, D., Steam reforming model compounds of biomass gasification tars: conversion at different operating conditions and tendency towards coke formation. Fuel Processing Technology 2001, 74 (1), 19-31.

77. Koh, J.-H.; Yoo, Y.-S.; Park, J.-W.; Lim, H. C., Carbon deposition and cell performance of Ni-YSZ anode support SOFC with methane fuel. Solid State Ionics 2002, 149 (3-4), 157-166.

78. He, H.; Hill, J. M., Carbon deposition on Ni/YSZ composites exposed to humidified methane. Applied Catalysis A: General 2007, 317 (2), 284-292.

79. Staniforth, J.; Kendall, K., Biogas powering a small tubular solid oxide fuel cell. Journal of Power Sources 1998, 71 (1-2), 275-277.

80. Baird, T.; Fryer, J. R.; Grant, B., Carbon formation on iron and nickel foils by hydrocarbon pyrolysis--reactions at 700 C. Carbon 1974, 12 (5), 591-602.

81. Chun, C. M.; Mumford, J. D.; Ramanarayanan, T. A., Carbon-Induced Corrosion of Nickel Anode. Journal of The Electrochemical Society 2000, 147 (10), 3680-3686.

82. Grabke, H. J.; R., K.; N., P. J. C., On the mechanism of catastrophic carburization: metal dusting. Corrosion Science 1993, 35, 1141.

83. Grabke, H. J., Thermodynamics, mechanisms and kinetics of metal dusting. Materials and Corrosion 1998, 49 (5), 303-308.

84. Rao, Y. K., Stoichiometry and Thermodynamics of Metallurgical Processes. Cambrige University Press: 1985; p 957.

85. Zhang, J.; Young, D. J., Kinetics and mechanisms of nickel metal dusting I. Kinetics and morphology. Corrosion Science 2007, 49 (3), 1496-1512.

86. Vogler, M.; Bieberle-Hutter, A.; Gauckler, L.; Warnatz, J.; Bessler, W. G., Modelling Study of Surface Reactions, Diffusion, and Spillover at a Ni/YSZ Patterned Anode. Journal of The Electrochemical Society 2009, 156 (5), B663-B672.

87. Ribeiro, N. F. P.; Souza, M. M. V. M.; Neto, O. R. M.; Vasconcelos, S. M. R.; Schmal, $\mathrm{M}$., Investigating the microstructure and catalytic properties of $\mathrm{Ni} / \mathrm{YSZ}$ cermets as anodes for SOFC applications. Applied Catalysis A: General 2009, 353 (2), 305-309.

88. Alvarez, L.; Guillard, T.; Sauvajol, J. L.; Flamant, G.; Laplaze, D., Growth mechanisms and diameter evolution of single wall carbon nanotubes. Chemical Physics Letters 2001, 342 (12), 7-14.

89. Motulsky, H.; Brown, R., Detecting outliers when fitting data with nonlinear regression a new method based on robust nonlinear regression and the false discovery rate. BMC

Bioinformatics 2006, 7 (1), 123. 
90. Hofer, L. J. E.; Cohn, E. M.; Peebles, W. C., The Isothermal Decomposition of Nickel Carbide. The Journal of Physical and Colloid Chemistry 1949, 54 (8), 1161-1169.

91. Freel, J.; Galwey, A. K., Kinetic Study of Nickel Carbide Formation. Transactions of the Faraday Society 1967, 63, 404-414.

92. Galwey, A. K., A Kinetic Investigation of the Reaction of Nickel Carbide with Hydrogen. Journal of Catalysis 1962, 1, 227-234.

93. Galwey, A. K., The Reactions of Nickel Carbide with a Number of Hydrogen-Containing or Oxygen-Containing Gaseous Compounds. Journal of Catalysis 1963, 2, 176-188.

94. Forzatti, P.; Lietti, L., Catalyst deactivation. Catalysis Today 1999, 52 (2-3), 165-181.

95. Trimm, D. L., Catalysts for the control of coking during steam reforming. Catalysis Today 1999, 49 (1-3), 3-10.

96. Bartholomew, C. H., Mechanisms of catalyst deactivation. Applied Catalysis A: General 2001, 212 (1-2), 17-60.

97. Ren, X. H.; Bertmer, M.; Stapf, S.; Demco, D. E.; Blümich, B.; Kern, C.; Jess, A., Deactivation and regeneration of a naphtha reforming catalyst. Applied Catalysis A: General 2002, 228 (1-2), 39-52.

98. Wiltner, A.; Linsmeier, C., Thermally induced reaction and diffusion of carbon films on Ni(1 11 1) and Ni(1 0 0). Surface Science 2008, 602 (23), 3623-3631.

99. Wiltner, A.; Linsmeier, C.; Jacob, T., Carbon reaction and diffusion on Ni(111), Ni(100), and Fe(110): Kinetic parameters from XPS and DFT analysis. The Journal of Chemical Physics 2008, 129 (8), 10. 